\title{
THE PURPOSES AND ACCOUNTABILITY OF THE CORPORATION IN CONTEMPORARY SOCIETY: CORPORATE GOVERNANCE AT A CROSSROADS
}

\author{
MichaEl BRADLEY, ${ }^{*}$ Cindy A. SCHIPANI, ${ }^{* *}$ ANANT K. SUNDARAM,*** AND
} JAMES P. WALSH****

\section{TABLE OF CONTENTS}

I. Introduction

II. Changes in the Conduct of the Business Enterprise .................................14

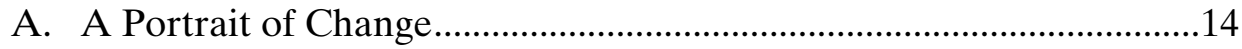

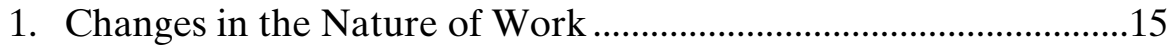

2. Changes in the Capital Market ........................................................17

3. Changes in Product-Market Competition ........................................19

4. Changes in Organizational Forms .................................................22

5. Changes in the Regulatory Environment .....................................24

B. The Implications of Change for Corporate Governance.....................29

III. Contemporary Corporate Governance Scholarship...................................33

A. Theories of Corporate Governance …................................................33

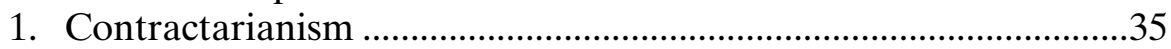

a. Contractarianism Defined .......................................................35

b. Implications of the Contractarian View....................................36

c. A Critique of Contractarianism ...................................................38

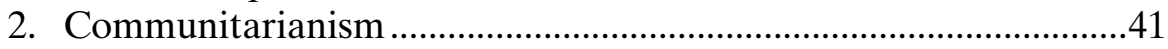

a. Communitarianism Defined ...................................................41

b. Implications of the Communitarian View ..................................44

c. A Critique of Communitarianism ...............................................45

Copyright (@ 2000 by Michael Bradley, Cindy A. Schipani, Anant K. Sundaram, and James P. Walsh

This article is also available at http://www.law.duke.edu/journals/62LCPBradley.

* F.M. Kirby Professor of Investment Banking, Fuqua School of Business and Professor of Law, Duke University.

** Professor of Business Law, University of Michigan Business School.

*** Associate Professor of Finance, Thunderbird, the American Graduate School of International Management.

**** Gerald \& Esther Carey Professor of Business Administration, University of Michigan Business School.

The authors gratefully acknowledge the research support of the Alfred P. Sloan Foundation and their respective institutions, the comments by Thomas Dunfee, Michael O'Hara, Douglas Park, and Gail Pesyna on an earlier version of this manuscript, and the valuable research assistance of Jet Vincent Arnaez, Brian Broughman, and Rachel Tausend. 
B. Toward a Practical Resolution: American Law Institute Section 2.01 and Beyond

C. Corporate Governance in a Comparative Setting ..............................50

1. The German Corporate Governance System …............................52

2. The Japanese Corporate Governance System ................................56

3. Assessment of the German and Japanese Governance Systems......................................................................................61

a. A Critique of German and Japanese Governance ..................64

b. Changes in the Governance Systems.......................................67

IV. The Purposes and Accountability of the Corporation ................................77

V. Voids at the Intersection of Sovereign Boundaries...................................79

VI. Conclusion

\section{INTRODUCTION}

Change is ubiquitous in contemporary society, and nowhere more so than in the operations of the large-scale, public corporation. Dramatic changes are underway, not only in the structure of corporate activity in areas such as the nature of work and the nature of organizational form, but also in the product and financial markets and the regulatory environment within which corporations operate.

The depth and rapidity of these changes compel a reassessment of the ability of various governance structures to cope and adapt. The consequences of these changes for governance have taken on an even greater sense of urgency in light of the transformations that have taken place in Eastern and Central Europe with the demise of the Soviet Union and with the economic convulsions of 1997 and 1998 in Southeast Asia. These events have brought into focus the nature of governance practices in those economies. The epic battle between capitalism and communism has largely been resolved in favor of capitalism-at least for the foreseeable future. Similarly, the reform questions in Southeast Asia are increasingly centered on the transition from one form of capitalism to another. Academics, practitioners, and policymakers, however, have an ambiguous vision of the type of capitalism that would best serve the economic and political order emerging in these parts of the world. The particular form of capitalism that ultimately will develop is substantially predicated on the institutions that will arise from this social upheaval and the organizational structures that will evolve for the provision of goods and services. Understanding this process will require not only an understanding of the nature of the changes that are underway, but also a reassessment of the paradigms of corporate governance and their ability to inform, respond to, and even shape such change.

Traditionally, the phrase "corporate governance" invokes a narrow consideration of the relationships between the firm's capital providers and top man- 
agers, as mediated by its board of directors. ${ }^{1}$ For example, Andrei Shleifer and Robert W. Vishny define corporate governance as the process that "deals with the ways in which suppliers of finance to corporations assure themselves of getting a return on their investment." " But corporate governance is more than simply the relationship between the firm and its capital providers. Corporate governance also implicates how the various constituencies that define the business enterprise serve, and are served by, the corporation. Implicit and explicit relationships between the corporation and its employees, creditors, suppliers, customers, host communities-and relationships among these constituencies themselves - fall within the ambit of a relevant definition of corporate governance. As such, the phrase calls into scrutiny not only the definition of the corporate form, but also its purposes and its accountability to each of the relevant constituencies. A basic goal of this article is to examine the changing nature of the business enterprise and its implications for the theory and practice of corporate governance across the range of corporate constituencies.

The academic literature in law, economics, finance, strategy, and management presumes that governance problems are largely a result of the "agency" problems that arise from the separation of ownership and control in the largescale, public corporation. Perhaps the best example of this perspective is the famous article by Michael C. Jensen and William H. Meckling, ${ }^{3}$ which, building upon the earlier works of Ronald Coase, ${ }^{4}$ Oliver E. Williamson, ${ }^{5}$ and Armen A. Alchian and Harold Demsetz, ${ }^{6}$ posits that the incentives of corporate managers to maximize shareholder value are proportional to the fraction of the firm's shares they hold in their personal portfolios. This narrow and limited view of the governance problem, one that focuses on just the relation between the firm and its capital providers, has become so dominant in the literature that it is almost automatically accepted. ${ }^{7}$

Empirical work testing this hypothesis typically involves a cross-sectional analysis in which the fraction of shares held by insiders is used as an independent variable to explain a number of performance measures-stock returns, return on investment, and accounting earnings-and firm characteristics-

1. See, e.g., Del. CODE ANN. tit. 8, § 141 (1991 \& Supp.); Oliver D. Hart, Corporate Governance: Some Theory and Implications, 105 ECON. J. 678 (1995).

2. Andrei Shleifer \& Robert W. Vishny, A Survey of Corporate Governance, 52 J. Fin. 737, 737 (1997).

3. See Michael C. Jensen \& William H. Meckling, Theory of the Firm: Managerial Behavior, Agency Costs and Ownership Structure, 3 J. Fin. ECON. 305, 305-11, 343-51 (1976).

4. See Ronald Coase, The Nature of the Firm, 4 ECONOMICA 386 (1937) (defining the firm).

5. See generally Olliver E. WiLliamson, THE ECONOMICS OF DisCRETIONARY BEHAVIOR: MANAGERIAL OBJECTIVES IN A THEORY OF THE FIRM (1964) (discussing managerial discretion and its relationship to a theory of the firm).

6. See generally Armen A. Alchian \& Harold Demsetz, Production, Information Costs, and Economic Organization, 62 AM. ECON. REV. 777 (1972) (discussing the team productive process as motivating organization into a firm).

7. Shleifer and Vishny readily admit that their "perspective on corporate governance is a straightforward agency perspective, sometimes referred to as separation of ownership and control." Shleifer \& Vishny, supra note 2, at 738. 
diversification, size, and risk. Much of this work in the fields of law, economics, and finance is masterfully summarized by Shleifer and Vishny, ${ }^{8}$ and need not be repeated here. Related work is found in the organization theory and strategy literatures as well. ${ }^{9}$ Other academic research attempts to link the nature and structure of managerial compensation to firm performance. The underlying premise is that stock-based compensation packages provide managers with greater incentives to maximize shareholder value.

Jensen extends the agency-cost theory to argue that managerial malfeasance is positively related to the amount of free cash flows that managers have at their disposal. ${ }^{11}$ Empirical tests of this theory typically use measures of free cash flow as an independent variable in cross-sectional analyses of firm performance. ${ }^{12}$ Likewise, there is an expanding literature that attempts to link the composition of the board of directors to firm performance. The underlying thesis is that outside directors are better, more objective monitors of managerial behavior, and, therefore, firms with greater outside representation on the board are run more in the interest of the firm's stockholders and less in the interest of self-serving managers. ${ }^{13}$

8. See id.; Michael J. Barclay \& Clifford G. Holderness, Private Benefits from Control of Public Corporations, 25 J. FIN. ECON. 371 (1989); Harold Demsetz \& Kenneth Lehn, The Structure of Corporate Ownership: Causes and Consequences, 93 J. POL. ECON. 1155 (1985); Paul H. Malatesta \& Ralph A. Walkling, Poison Pill Securities: Stockholder Wealth, Profitability, and Ownership Structure, 20 J. FIN. ECON. 347 (1988); John J. McConnell \& Henri Servaes, Additional Evidence on Equity Ownership and Corporate Value, 27 J. FIN. ECON. 595 (1990); Randall Morck et al., Management Ownership and Market Valuation: An Empirical Analysis, 20 J. FIN. ECON. 293 (1988); René M. Stulz, Managerial Control of Voting Rights: Financing Policies and the Market for Corporate Control, 20 J. FIN. ECON. 25 (1988).

9. See, e.g., Rajeswararao Chaganti \& Fariborz Damanpour, Institutional Ownership, Capital Structure, and Firm Performance, 12 STRATEgIC MgMT. J. 479 (1991); Gary S. Hansen \& Charles W.L. Hill, Are Institutional Investors Myopic? A Time-Series Study of Four Technology-Driven Industries, 12 Strategic Mgmt. J. 1 (1991); Charles W.L. Hill \& Scott A. Snell, Effects of Ownership Structure and Control on Corporate Productivity, 32 ACAD. MGMT. J. 25 (1989).

10. Important studies on the relation between the pay and performance of corporate managers include the following: KEVIN J. MURPHY, 3 HANDBOOK OF LABOR ECONOMICS 70 (1999); Michael C. Jensen \& Kevin J. Murphy, Performance Pay and Top-Management Incentives, 98 J. POL. ECON. 225 (1990); Kevin J. Murphy, Corporate Performance and Managerial Remuneration: An Empirical Analysis, 7 J. ACCT. \& ECON. 11 (1985); Andrei Shleifer \& Robert W. Vishny, Value Maximization and the Acquisition Process, J. ECON. PERSP., Winter 1988, at 7; David Yermack, Good Timing: CEO Stock Option Awards and Company News Announcements, 52 J. FIN. 449 (1997). Related studies in the management literature discuss the relationship between managerial control and executive compensation. See, e.g., Randolph P. Beatty \& Edward J. Zajac, Managerial Incentives, Monitoring, and Risk Bearing: A Study of Executive Compensation, Ownership, and Board Structure in Initial Public Offerings, 39 ADMIN. SCI. Q. 313 (1994); Donald C. Hambrick \& Sydney Finkelstein, The Effects of Ownership Structure on Conditions at the Top: The Case of CEO Pay Raises, 16 STRATEGIC MGMT. J. 175 (1995); Richard A. Lambert et al., Portfolio Considerations in Valuing Executive Compensation, 29 J. ACCT. RES. 129 (1991); Henry Tosi, Jr. \& Luis R. Gomez-Mejia, CEO Compensation Monitoring and Firm Performance, 37 ACAD. MGMT. J. 1002 (1994).

11. See Michael C. Jensen, Agency Costs of Free Cash Flow, Corporate Finance, and Takeovers, 76 AM. ECON. REV., May 1986, at 323; Michael C. Jensen, Eclipse on the Public Corporation, 67 HARV. Bus. REV., Sept.-Oct. 1989, at 60, 66.

12. See, e.g., Larry H.P. Lang et al., A Test of the Free Cash Flow Hypothesis: The Case of Bidder Returns, 29 J. FIN. ECON. 315 (1991).

13. See generally the following articles relating to this thesis: James F. Cotter et al., Do Independent Directors Enhance Target Shareholder Wealth During Tender Offers?, 43 J. FIN. ECON. 195 (1997); 
There is also an extensive literature involving the relation between corporate governance structures-including insider ownership, managerial compensation, and board composition-and such corporate events as mergers, hostile takeovers, divestitures, and bankruptcies, as well as changes in the firm's capital structure, dividend policy, and investment strategy. ${ }^{14}$ Numerous studies examine the relations between governance structures and changes in the legal environment including changes in the tax code, state and federal statutes, and judicial decisions. ${ }^{15}$

Recently, Rafael La Porta, Florencio Lopez-de-Silanes, Andrei Shleifer, and Robert W. Vishny have taken the cross-sectional analysis of governance structures to a new level. ${ }^{16}$ Extending the analysis beyond the firm, they relate country-specific variables, essentially the degree to which stockholders' rights are defined and protected by law, to the relative size of the external equity market in that country. ${ }^{17}$ Not surprisingly, they find a positive relation between shareholder protections and the size of the country's external capital market. ${ }^{18}$ However, while cross-sectional studies provide important insights into the relative efficiency of different governance structures at a point in time, they shed little or no light on how governance structures evolve through time. Little at-

Michael C. Jensen, The Modern Industrial Revolution, Exit, and the Failure of Internal Control Systems, 48 J. Fin. 831, 864-65 (1993); Idalene F. Kesner, Directors' Characteristics and Committee Membership: An Investigation of Type, Occupation, Tenure, and Gender, 31 ACAD. MGMT. J. 66 (1988) (arguing that low outside director representation on key committees negatively affects stockholder representation); April Klein, Firm Performance and Board Committee Structure, 41 J.L. \& ECON. 275 (1998); Laura Lin, The Effectiveness of Outside Directors as a Corporate Governance Mechanism: Theories and Evidence, 90 Nw. U. L. REV. 898 (1996); Mark S. Mizruchi \& Linda Brewster Stearns, A Longitudinal Study of Borrowing by Large American Corporations, 39 ADMIN. SCI. Q. 118, 123-24 (1994); Michael C. Weisbach, Outside Directors and CEO Turnover, 20 J. FIN. ECON. 431, 433-35 (1988); Shaker A. Zahra \& John A. Pearce II, Boards of Directors and Corporate Financial Performance: A Review and Integrative Model, 15 J. MGMT. 291 (1989); Sanjai Bhagat \& Bernard Black, Board Independence and Long-Term Firm Performance (University of Colorado and Columbia Law School Working Paper, 1996). Interestingly, a recent meta-analysis of 54 studies of the relationship between board corporation and financial performance found little evidence for such a tie. See Dan R. Dalton et al., MetaAnalytic Reviews of Board Composition, Leadership Structure, and Financial Performance, 19 STRATEGIC MGMT. J. 269 (1998) (arguing that there is very little evidence that board composition and firm performance are related).

14. See the following literature analyzing this relationship: Catherine M. Daily, The Relationship Between Board Composition and Leadership Structure and Bankruptcy Reorganization Outcomes, 21 J. MGMT. 1041 (1995); Wilber Lewellen et al., Merger Decisions and Executive Stock Ownership in Acquiring Firms, 7 J. ACCT. \& ECON. 209 (1985); Anil Shivdasani, Board Composition, Ownership Structure, and Hostile Takeovers, 16 J. ACCT. \& ECON. 167 (1993). See generally the following articles dealing with corporate governance structures and corporate events: Ronald J. Gilson \& Reinier Kraakman, Reinventing the Outside Director: An Agenda for Institutional Investors, 43 STAN. L. REV. 863 (1991); James J. Hanks, Jr., Evaluating Recent State Legislation on Director and Officer Liability Limitation and Indemnification, 43 BUS. LAw. 1207 (1988); Roberta Romano, Corporate Governance in the Aftermath of the Insurance Crisis, 39 EMORY L.J. 1155 (1990). For cases dealing with corporate governance structures and corporate events, see generally Hanson Trust PLC v. ML SCM Acquisition Inc., 781 F.2d 264 (2d Cir. 1986), and Smith v. Van Gorkom, 488 A.2d 858 (Del. 1985).

15. See, e.g., Myron S. Scholes \& Mark A. Wolfson, TAXes and Business Strategy: A PlanNing ApPROACH (1992); Michael Bradley \& Cindy A. Schipani, The Relevance of the Duty of Care Standard in Corporate Governance, 75 IOWA L. REV. 1 (1989).

16. See Rafael La Porta et al., Legal Determinants of External Finance, 52 J. FIN. 1131 (1997).

17. See id. at 1132 .

18. See id. at $1149-50$. 
tention has been paid to how the governance structures of public corporations adapt to structural changes in the social, political, economic, and legal environments in which they operate. ${ }^{19}$ This article attempts to begin to fill this void.

Specifically, this article has four purposes: (1) to chronicle the recent changes in the conduct of the business enterprise; (2) to review and critique four broad responses to these changes, as found in both the theories and the practice of corporate governance; (3) to establish the necessary conditions for a system of corporate governance capable of accommodating these changes; and (4) to articulate an agenda for research, policy, and practice in light of our view of the purposes and the accountability of the corporation. To this last point, after careful analysis, we conclude that the Anglo-American governance system, born of the contractarian paradigm, is the most flexible and effective system available. Notwithstanding its idiosyncratic historical origins and its limitations, it is clearly emerging as the world's standard. Therefore, it is very important to understand its limitations. These limitations are of two types. First, it is necessary to understand and address the problems that hinder the system's efficiency. A worldwide contractarian infrastructure that establishes exacting disclosure rules, a coherent body of contract law, and an independent judiciary is as essential as it is unlikely. Therefore, understanding how to hold firms accountable absent such an infrastructure is one of the most pressing contemporary governance challenges. A worldwide market for corporate control holds promise for some discipline in this emerging system. The second set of limitations are limitations on the Anglo-American system itself. Problems of economic efficiency and social welfare rooted in the limitations of incomplete contracting, negative externalities, and abuses of power can be explained, but not explained away. Solutions to these problems are particularly elusive.

II

CHANGES IN THE CONDUCT OF THE BUSINESS ENTERPRISE

\section{A. A Portrait of Change}

Dramatic transformations are underway in at least five crucial areas that characterize the internal organization and external environment of the public corporation: (1) the nature of work; (2) the capital market; (3) product-market competition; (4) organizational forms; and (5) regulatory environment.

19. Of course the notable exception is the recent work in the legal literature pertaining to the evolution of financial institutions and the role of path dependencies. Mark Roe's account of the evolution of corporate governance in the United States is clearly a time-series perspective. See generally Mark J. Roe, Strong Managers, Weak Owners: The Political RoOTs of American CORPORATE FINANCE (1994). Moreover, those who believe that social rigidities in certain countries preclude any opportunity for meaningful changes in corporate governance also rely on a timedependency argument. For an analysis of the Japanese corporate system, see, for example, Ronald J. Gilson \& Mark J. Roe, Understanding the Japanese Keiretsu: Overlaps Between Corporate Governance and Industrial Organization, 102 YALE L.J. 871 (1993). 
1. Changes in the Nature of Work. The development of information, communication, and automation technologies has fundamentally changed the nature of work inherited from the eighteenth century beginnings of the Industrial Revolution. ${ }^{20}$ Peter F. Drucker and Jeremy Rifkin identify the period starting soon after World War II as the turning point. ${ }^{21}$ Five key differences in the nature of work appear to define these changes:

(1) Whereas land, labor, and capital were once the key factors of production in a system where profits resided in manufacturing volume, today knowledge is the key factor of production in value creation; ${ }^{22}$

(2) Whereas workers used to serve machines and capital, today machines and capital serve workers (that is, technology that used to amplify our muscles today amplifies our intellect) ${ }^{23}$

(3) Whereas specialization, standardization, and mechanization provided the logic for industrial work, today problem-identifying, problem-solving, and strategic-brokering provide the logic for knowledge-based work $;^{24}$

(4) Whereas workers were historically selected for their skills of exertion, dexterity, and endurance, today skills of perception, attentiveness, and decisionmaking are valued; ${ }^{25}$ and

(5) Whereas formal education was largely seen as irrelevant to the activity of wealth accumulation, today human capital investments in formal education are seen as a key to accumulating wealth. ${ }^{26}$

As specialized human capital becomes more central and critical to the production process, individuals with such capital become more powerful in the or-

20. Much has been written about these changes. For an excellent summary of this argument, see CATHERINe CASey, Work, Self AND SOCIETy 26-49 (1995). Peter F. Drucker, PostCAPITAlist SOCIETY (1993), and ROBERT B. REICH, THE WORK OF NATIONS (1991), popularized consideration of these changes. See also William Greider, One World, ReAdy OR Not: The MANIC LOGIC OF GLOBAL CAPITALISM (1997) (discussing globalization); JEREMY RIFKIN, THE END OF WORK: THE DECline OF THE GLOBAL LABOR FORCE AND THE DAWN OF THE POST-MARKET ERA (1995) (examining how work has changed in the past fifty years); SHOSHANA ZUBOFF, IN THE AgE OF THE SMART MACHINE: THE FUTURE OF WORK AND POWER (1988) (discussing technological changes).

21. DRUCKER, supra note 20 at 3,19-47; RIFKIN, supra note 20, at 60.

22. See DRUCKER, supra note 20, at $44-45$ (noting that land, labor, and capital are now seen as constraints).

23. See id. at 64-65. Drucker points out that a computer, ultrasound machine, or radio telescope is unproductive without a knowledgeable employee putting it to use. See id. at 65 . He concludes that "capital now serves the employee, where under Capitalism the employee served capital." Id. at 67.

24. See CASEY, supra note 20, at 26 (reviewing how specialization, standardization, and mechanization were the fundamental processes of industrial work); REICH, supra note 20, at 171-84 (discussing how identifying, solving, and brokering problems define the nature of work in the new, emerging economy).

25. See CASEY, supra note 20, at 37 .

26. See DRUCKER, supra note 20, at 40-42. Drucker points out that of all the very successful 19th century American capitalists, only one went to college-J.P. Morgan-and he dropped out after one year. See id. at 41. "Higher education was considered a luxury, an ornament, and a pleasant way to spend one's early adulthood." Id. at 41 . Reich, however, argues that notwithstanding the importance of education to wealth accumulation today, only 15 to $20 \%$ of American children are prepared for what he calls symbolic-analytic work. See REICH, supra note 20, at 227. 
ganization. ${ }^{27}$ Importantly, these individuals are also much more difficult to monitor and control. William G. Ouchi notes that when the outcomes of a person's work are difficult to measure and when the means to this end are difficult to prescribe, then typical approaches to control are problematic. ${ }^{28}$ Outcome controls, such as writing contracts that reward the successful performance of some tasks, and behavioral controls, which include closely supervising individuals to ensure that their work is done properly, do not work well in these circumstances. Rather, Ouchi argues that clan control, or what might be called cultural control, is necessary in these situations. ${ }^{29}$ Therefore, absent prescribed means and measurable ends, the firm must work to ensure that the goals and values of the individual are consonant with the goals and values of the firm. Firm-interests and self-interest must be aligned. ${ }^{30}$

However, cultural control is problematic in the best of times, ${ }^{31}$ and scholars have pointed out that this kind of hegomonic control insidiously robs individuals of their humanity. ${ }^{32}$ John Van Maannen and Gideon Kunda's work, for example, traces the evolution in the various approaches to the control of individuals in organizations and concludes by worrying about the "social molestation" that marks such contemporary approaches to control. ${ }^{33}$

The problem is that these are not necessarily the best of times. ${ }^{34}$ The corpo-

27. See JefFrey Pfeffer, Power in Organizations 99-115 (1981) (discussing how dependence, providing resources, coping with uncertainty, and becoming irreplaceable all work to create power in organizations).

28. See William G. Ouchi, A Conceptual Framework for the Design of Organizational Control Mechanisms, 25 MGMT. SCI. 833 (1979).

29. See id.

30. Trade books instruct managers on how to build such cultures. See, e.g., TERRENCE E. DEAL \& Allan A. Kennedy, Corporate Cultures: The Rites and Rituals of Corporate Life (1982); William G. OUCHI, TheORY Z (1981). See also Stephen R. Barley et al., Cultures of Culture: Academics, Practitioners and the Pragmatics of Normative Control, 33 ADMIN. SCI. Q. 24 (1988) (tracing the evolution of this corporate culture movement); Charles O'Reilly, Corporations, Culture and Commitment: Motivation and Social Control in Organizations, CAL. MGMT. ReV., Summer 1989, at 9 (discussing, in a practice-oriented journal, how to manage culture to this same end).

31. Gideon Kunda's rich case study reveals how difficult it is to control employees using this cultural approach. See generally GideOn KUndA, ENGINEERING CUlture: Culture AND COMMITMENT IN A HIGH-TECH CORPORATION (1992).

32. See, e.g., Hugh Willmott, Strength Is Ignorance; Slavery Is Freedom: Managing Culture in Modern Organizations, 30 J. MGMT. STUD. 515 (1993).

33. John Van Maannen \& Gideon Kunda "Real Feelings": Emotional Expression and Organizational Culture, RES. ORG. BEHAV. 43, 92 (1989).

34. This characterization may surprise those who think of "good times" in purely economic terms. Yes, a portion of the American population has benefited quite handsomely from the recent economic expansion, but a sizable portion of the American population has not benefited much at all from this new wealth creation. Recent empirical work has documented the rising wage inequality in the United States. See C. Juhn et. al., Wage Inequality and Rise in Returns to Skill, 101 J. PoL. ECON. 410-42 (1993) (examining the 1963 to 1989 time period); Lawrence F. Katz, Technological Change, Computerization, and the Wage Structure (1999) (unpublished manuscript, on file with Harvard University and the National Bureau of Economic Research) (examining the 1940 to 1998 time period). We do not mean to quibble about the distribution of these economic gains, rather we want to raise the issue concerning the nature of managerial life in these turbulent times. 
rate downsizings with their accompanying layoffs and dismissals ${ }^{35}$ - born of a need to address overcapacity problems rooted in part in the technological improvements associated with these changes in the nature of work $^{36}$-have unnerved a generation of managers. ${ }^{37}$ Firm interests have been at odds with at least some individuals' self-interest in this period, ${ }^{38}$ prompting observers to advise employees to resist attempts to become dependent on any one firm and instead to become "Free Agent Manager[s]." Others comment on the rise of cynicism. ${ }^{40}$ All in all, the changes in the nature of work have rendered control in organizations problematic. ${ }^{41}$

2. Changes in the Capital Market. The capital market environment also has changed dramatically in the past twenty to thirty years. Merton H. Miller colorfully captures this phenomenon:

The wonderment of Rip Van Winkle, awakening after his sleep of 20 years to a changed world, would pale in comparison to that felt by one of his descendants in the banking or financial services industry falling asleep (presumably at his desk) in 1970 and waking two decades later. So rapid has been the pace of innovation in financial instruments and institutions over the last 20 years that nothing could have prepared him to understand such now commonplace notions as swaps and swaptions, index futures, program trading, butterfly spreads, puttable bonds, Eurobonds, collateralizedmortgage bonds, zero-coupon bonds, portfolio insurance, or synthetic cash-to name just a few of the more exotic ones. No 20-year period has witnessed such a burst of innovative activity. ${ }^{42}$

Three broad areas of change stand out when considering the innovations in financial instruments and institutions: (a) the emergence of an international capital market; (b) the rise of the institutional investor; and (c) the unprecedented proliferation of financial products. ${ }^{43}$

35. See generally The New York Times, The New York Times Special Report: The DOWNSIZING OF AMERICA (1996).

36. See generally Jensen, supra note 13 .

37. See James P. Walsh, Managers Under Siege: Corporate Control Contests and Management Turnover, in HANDBOOK OF BUSINESS STRATEGY $\$ \$ 15.1-.15$ (Harold E. Glass ed., 2d ed. 1991).

38. See generally Andrei Shliefer \& Laurence H. Summers, Breach of Trust in Hostile Takeovers, in Corporate Takeovers: Causes AND Consequences 33-67 (Alan J. Auerbach ed., 1988) (discussing how firms can benefit from reneging on promises to their employees). Others question whether firms and employee interests have ever been completely aligned. See, e.g., Marleen A. O'Conner, Organized Labor as Shareholder Activist: Building Coalitions to Promote Worker Capitalism, 31 U. RICH. L. REV. 1345 (1997) (discussing strategies that labor might employ to meet their needs in the contemporary economic environment).

39. Paul Hirsch, Pack Your Own Parachute: How to Survive Mergers, Takeovers, AND OTHER CORPORATE DISASTERS 119 (1987).

40. See generally Donald L. KANTER \& Philip H. Mirvis, The Cynical AMERICANS: Living AND WORKING IN AN AGE OF DisCONTENT AND Disillusion (1989); James W. Dean, Jr. et al., Note, Organizational Cynicism, 23 ACAD. MGMT. REV. 341 (1998).

41. Azizah Y. al-Hibri's vision of corporate democracy as a necessary complement to the changes that define the information age is a fine example of how scholars are trying to come to terms with these problematic control issues. See Azizah Y. al-Hibri, The American Corporation in the TwentyFirst Century: Future Forms of Structure and Governance, 31 U. RICH. L. REV. 1399, 1438 (1997).

42. Merton H. Miller, Financial Innovation: Achievements and Prospects, J. APPLIED CORP. FIN., Winter 1992, at 4.

43. See, e.g., id. (discussing these broad areas). 
The most profound change in the capital market over the past two decades has been its transformation from a conglomeration of regionally and nationally segmented markets into one integrated, international market. For example, in 1970, the total amount of debt and equity traded between U.S. residents and nonresidents was less than three percent of gross domestic product ("GDP"). In 1997 , the figure was more than $213 \%$. ${ }^{45}$ International trade of stocks and bonds in Japan rose from less than two percent of GDP in 1975 to almost ninety-six percent in $1997 .{ }^{46}$ In the United Kingdom, the international trading of securities amounted to almost $700 \%$ of that country's gross domestic product in $1990{ }^{47}$ The implication of the emergence of a global capital market is that neither investors nor firms are constrained by their national borders to invest in or issue financial securities. Data from the Bank for International Settlements report end-of-year net stocks for international bond financing at \$2.21 trillion in 1995, up from $\$ 700$ billion in $1986 .^{48}$ Annual volume of international bond issues averaged more than $\$ 350$ billion during the period 1990 to 1995 . $^{49}$ Crossborder trade in equities grew at a rate of about twenty-eight percent per year from 1980 to 1990 , and annual volumes now approach $\$ 1.5$ trillion per year. ${ }^{50}$

The second major change in the capital market over the past twenty years has been the rise of the institutional investor. In 1977, there were only 427 registered, public mutual funds in the United States, representing a total of fortyfive billion dollars and only 8.5 million shareholders (separate accounts). By 1996, there were 5,305 registered mutual funds representing \$2.6 trillion and almost 120 million separate accounts. ${ }^{51}$ Institutional investors hold slightly less than fifty percent of the outstanding equity of all U.S. corporations, ${ }^{52}$ but even more impressively, account for more than eighty percent all shares traded. ${ }^{53}$ Between 1980 and 1996, pension fund assets in the United States have grown from $\$ 873$ billion to $\$ 5.9$ trillion. $^{54}$ The percentage of U.S. equity held by pension funds expanded from nine percent in 1970 to almost twenty-four percent in $1997 . .^{55}$

44. See 1992 BANK FOR InT'L SETtLEMENTS ANN. REP. 193 [hereinafter 1992 BIS REPORT]; see also Anant K. Sundaram, International Financial Markets, in HANDBOOK OF MODERN FINANCE $\S$ F3.01-.02 (Dennis E. Logue ed., 1994).

45. See InTERnATIONAL MONETARy FUnD, InTERnATIONAL CAPITAL MARKETS: DEVELOPMENTS, PROSPECTS, AND KEY POLICY ISSUES, WORLD ECONOMIC AND FINANCIAL SURVEYS, 187 (1998).

46. See id.

47. See 1992 BIS REPORT, supra note 44, at 194.

48. See 1996 BANK FOR INT'L SETTLEMENTS ANN. REP. 122.

49. See id.

50. See Sundaram, supra note 44 , at 63-64.

51. See InVESTMENT COMPANy Institute, Mutual Fund FACt BooK (37th ed. 1997).

52. See Bureau of Census, U.S. Dep't of Commerce, Statistical Abstract of the UNITED STATES 524 tbl.808 (1997) [hereinafter 1997 ABSTRACT].

53. See Stephen L. Nesbitt, Long-Term Rewards from Shareholder Activism: A Study of the “calPERS Effect," J. APPLIED CORP. FIN., Winter 1994, at 75.

54. See 1997 ABSTRACT, supra note 52, at 531.

55. See New York Stock Exchange Public Relations \& Marketing Division, New YORK STOCK EXCHANGE FACT BOOK 62 (1997). 
The third major change that has occurred in the capital market is the proliferation of financial products. John D. Finnerty identifies sixty major innovations in securities offered by corporations between just 1973 and 1991, and many more have been added since then. ${ }^{56}$ He lists a number of factors that led to the development of these new financial products: risk reallocation; enhanced liquidity; the reduction in agency costs, transactions costs, and taxes; and the circumvention of regulatory restrictions. ${ }^{57}$ Almost forty of these innovations involve debt instruments, including adjustable rate notes, bonds linked to commodity prices, collateralized mortgage obligations, commercial real estate-backed bonds, credit card receivable-backed bonds, global bonds, pay-inkind debentures, puttable bonds, stripped mortgage-backed securities, and variable coupon renewable notes. ${ }^{58}$ Innovations in the equity market include callable common stock, supershares, and unbundled stock units. ${ }^{59}$ Important innovations since 1992 include targeted stock and other forms of project-based financing. ${ }^{60}$

Perhaps the most significant innovation in financial products, however, has been in the area of derivative securities. As the name implies, the payoffs to these securities are determined by or derived from the payoffs to other, primary assets. The estimated total value of the derivatives market as of June 1998 was seventy trillion dollars. ${ }^{61}$ In general, these innovations in financial instruments represent a change from the generic and standardized to the specific and customized, while, simultaneously, the institutional context of financial markets is becoming more homogenous worldwide.

3. Changes in Product-Market Competition. Corporate product-market globalization (that is, the process by which corporate product-market activity becomes worldwide in scope) is no longer news. However, what is less well known is the extent and recent acceleration of the phenomenon. Recent data from the United Nations reveal that, as of 1996, there were nearly 44,000 multinational enterprises ("MNEs") worldwide with nearly 280,000 affiliates, and assets of about $\$ 8.4$ trillion. $^{62}$ The industrialized world accounted for about 36,000 , or about eighty-two percent, of these MNEs, a number that grew by more than 29,000 (that is, more than $400 \%$ ) since the end of the $1960 \mathrm{~s}^{63}$

56. See John D. Finnerty, An Overview of Corporate Securities Innovation, J. APPLIED CORP. FIN., Winter 1992, at 23, 24, 29-32.

57. See id. at 24.

58. See id. at 29-32.

59. See id. at 38.

60. See generally Dennis E. Logue et al., Rearranging Residual Claims: A Case for Targeted Stock, FIN. MGMT., Spring 1996, at 43.

61. See BAnK For InT’L Settlements, Int’L BAnking Fin. MKt. DeV. 31 (Mar. 1999).

62. See U.N. CONFERENCE ON TRADE AND DEV., WORLD INVESTMENT REPORT 1997: Transnational CORPorations, MARKET STRUCTURE AND COMPETITION POLICY at 3-7, U.N. Sales No. E.97.11.D.10 (1997) (the term "MNEs" is interchangeable with the term "transnational corporations" ("TNC")).

63. See id. at 6-7. The data on MNE growth is derived from a 1994 report of the United Nations which states that there were approximately 7,000 MNEs in the late 1960s. See U.N. CONFERENCE ON 
Table 1 provides an evolutionary look at the globalization of the U.S. economy along two indicators: foreign trade as a proportion of U.S. gross national product ("GNP") and inward and outward direct foreign investment ("DFI") as a proportion of U.S. GNP. ${ }^{64}$

TABLE 1

ROLE OF EXPORTS, IMPORTS, FOREIGN DIRECT INVESTMENT INTO THE UNITED STATES (FDIUS), AND U.S. DIRECT INVESTMENT ABROAD (USDIA) IN THE U.S. ECONOMY: 1950-1994

\begin{tabular}{ccccccc}
\hline Year & $\begin{array}{c}\text { Exports as } \\
\text { \% GNP }\end{array}$ & $\begin{array}{c}\text { Imports as } \\
\% \text { GNP }\end{array}$ & $\begin{array}{c}\text { Exports }+ \\
\text { Imports as } \\
\text { \% GNP }\end{array}$ & $\begin{array}{c}\text { FDIUS as } \\
\text { \% GNP }\end{array}$ & $\begin{array}{c}\text { USDIA as } \\
\% \text { GNP }\end{array}$ & $\begin{array}{c}\text { FDIUS + } \\
\text { USDIA a } \\
\text { \% GNP }\end{array}$ \\
\hline 1950 & 4.29 & 4.04 & 8.33 & 1.18 & 4.11 & 5.30 \\
1960 & 4.93 & 4.44 & 9.37 & 1.34 & 6.21 & 7.56 \\
1970 & 5.64 & 5.52 & 11.16 & 1.34 & 7.74 & 9.07 \\
1980 & 10.31 & 10.85 & 21.16 & 3.06 & 7.95 & 11.02 \\
1990 & 10.04 & 11.33 & 21.38 & 7.12 & 7.76 & 14.88 \\
1994 & 10.67 & 12.12 & 22.79 & 7.49 & 9.08 & 16.50 \\
\hline
\end{tabular}

Source: Bureau of Census, U.S. Dep’t of Commerce, Statistical Abstract of the United States 287 tbls.337-38, 885 tbl.1096 (1955); Historical Statistics of the United States: Colonial Times to 1957, A U.S. Statistical Abstract Supplement 139 tbl.F1-5, 537 tbl.U1-14, 565 tbls.U193-206 (1960); BuREAU of CENSUS, U.S. DeP’T OF Commerce, Statistical Abstract of the United States 380-81 tbls.614 and 616, 79899 tbl.1342-44 (1975); Bureau of Census, U.S. DeP't of Commerce, Statistical Abstract OF THE United STATES 432 tbl.715, 802 tbl.1426, 803 tbl.1428 (1985); BuREaU of Census, U.S. Dep't of Commerce, Statistical Abstract of the United States 451 tbl.699, 809 tbl.1329 (1995).

In 1950, exports and imports accounted for about eight percent of U.S. GNP; by 1994, this figure had risen to twenty-three percent. ${ }^{65}$ Similarly, in 1950, inward and outward DFI accounted for 5.3\% of U.S. GNP; by 1994, it was

Trade And DeV., World InVESTMEnt Report 1994: Transnational Corporations, EMPLOYMENT AND THE WORKPLACE at xxi, U.N. Sales No. E.94.II.A.14 (1994).

64. See Bureau of Census, U.S. Dep't of Commerce, Statistical Abstract of the UNITED STATES 287 tbl.337-38, 885 tbl.1096 (1955); HisTORICAL STATISTICS OF THE UNITED STATES: COlONial Times to 1957, A U.S. STATISTICAL ABSTRACT SUPPLEMENT 139 tbl.F1-5, 537 tbl.U1-14, 565 tbls.U193-206 (1960); BUREAU OF CENSUS, U.S. DEP'T OF COMMERCE, STATISTICAL ABSTRACT OF THE UNITED STATES 380-81 tbls.614 and 616, 798-99 tbl.1342-44 (1975); BUREAU OF CENSUS, U.S. DeP'T OF COMMERCE, STATISTICAL ABSTRACT OF THE UNITED STATES 432 tbl.715, 802 tbl.1426, 803 tbl.1428 (1985); Bureau of CENSUS, U.S. DeP'T OF COMMERCE, STATistiCAL AbSTRACT OF THE UNITED STATES 451 tbl.699, 809 tbl.1329 (1995) [hereinafter 1995 ABSTRACT]. 65. See 1995 ABSTRACT, supra note 64, at 451 tbl.699. 
more than $16.5 \%{ }^{66}$ Given that MNEs account for a sizable proportion of foreign trade in the United States and nearly one hundred percent of DFI, these two statistics taken together reveal a substantial increase in the role of MNEs in U.S. product markets.

Considering detailed data for the United States in 1996, more than eightyeight percent of U.S. non-bank corporate assets were accounted for by firms defined as (U.S. non-bank) MNEs by the U.S. Department of Commerce. ${ }^{67}$ These firms held twenty-eight percent of these assets, derived thirty-three percent of their sales, and located twenty-nine percent of their employees abroad. ${ }^{68}$ Another indication of the MNE presence in the U.S. economy is in the area of international trade. In 1996, U.S. MNEs accounted for sixty-five percent of all U.S. exports of goods and services, while U.S. operations of foreign MNEs accounted for another twenty-two percent; U.S. MNEs accounted for forty percent of all U.S. imports of goods and services, and U.S. operations of foreign MNEs thirty-two percent. ${ }^{69}$ Thus, MNEs accounted for eighty-seven percent of all exports and seventy-two percent of all imports in the U.S. economy.

The volume of both cross-border mergers and acquisitions ("M\&A") and strategic alliances - two of the important means by which firms implement their product market globalization strategies-saw impressive increases during the last two decades. According to figures released by the United Nations, the period 1990 to 1997 alone witnessed nearly \$1.6 trillion in cross-border mergers and acquisitions; ${ }^{70}$ approximately ten percent of all U.S. M\&A activity from 1985 to 1994 took place across borders, and approximately twenty percent of all non-U.S. M\&A activity involved foreign firms merging with or acquiring U.S. firms. ${ }^{71}$ The period 1980 to 1989 saw nearly 700 cross-border strategic alliances in the information technology industry, 280 in biotechnology, 140 in new materials, and more than eighty in the automotive sector. ${ }^{72}$

The data above provide only partial evidence of the importance and recent acceleration of corporate globalization. There are other less measurable and less tangible, but equally important, aspects of globalization that have under-

66. See id. Bureau of Census, U.S. Dep't of Commerce, Statistical Abstract of the UNITED STATES 788 tbl.1288, 791 tbl.1293 (1996).

67. In 1996, U.S. non-bank MNEs had $\$ 10.88$ trillion in assets (data includes the asset base of the foreign affiliates of the U.S. parent company). See Raymond J. Mataloni, Jr., U.S. Multinational Companies: Operations in 1996, SURV. CURRENT BUS., Sept. 1998 , at 31, 66 tbl.17.2, 67 tbl.18. Total assets in 1996 of all non-bank U.S. corporations were \$12.28 trillion. See U.S. BuREAU OF Census, StATISTICAL ABSTRACT OF THE UNITED STATES 544 tbl.862 (1998).

68. U.S. MNEs had $\$ 10.88$ trillion in assets, with $\$ 3.075$ trillion located abroad; $\$ 6.73$ trillion in sales, with $\$ 2.23$ trillion abroad; 26.39 million employees, with 7.62 million located abroad. See Mataloni, Jr., supra note 67, at 66-67.

69. See id. at 37 n.6, 49, 52 .

70. See U.N. World InVESTMENT Report 1998: Trends AND DETERMinAnts, United Nations Conference on Trade And DeVelopment at 413 annex tbl.B7, U.N. Sales No. E.98II.D.5 (1998).

71. See Cross-Border $M \& A$, MERgers \& ACQuisition, May-June 1995, at 61.

72. See OfFice of TeChNOlogy Assessment, Multinationals and the National InTEREST: PlAYING BY DIFFERENT RULES 71 (Sept. 1993). 
gone dramatic change in the past few decades. The source of competition for firms in many important sectors of the economy is de facto global. Examples of such industries include automobiles, commercial aircraft, semiconductors, shipping, electronics, telecommunications, chemicals, xerography, pharmaceuticals, and publishing. ${ }^{73}$ Firms must respond to product-market moves that their foreign competitors make, whether such moves are through the technologies, products, and markets they develop, their manufacturing processes, their product quality, or their pricing decisions. The competitive impact of factors like these is impossible to measure. Equally difficult to measure are other intangible aspects of globalization such as the stimulating macroeconomic effects of investments from abroad; the managerial and organizational innovations (for example, just-in-time, lean production, decisionmaking styles) that are transferred across borders; the positive spillover effects of global competition that keep firms on their toes in both product and process innovation, productivity, and quality; and the pressure to upgrade and diversify job skills in this new economy. ${ }^{74}$

While this portrait of contemporary MNE activity is impressive for its reach, its effect on an understanding of governance is made all the more challenging because of its rapid development. The phenomenon of corporate globalization represents a disjunctive change in the conduct of the business enterprise.

4. Changes in Organizational Forms. Until recently, it has been possible to describe the various organizational forms that have emerged since the industrial revolution in terms of variations on the common themes of functional, multidivisional, matrix, or holding company structures. ${ }^{75}$ However, during the past fifteen years, it has been a challenge to develop a vocabulary to describe the new, emergent forms of organization. The terms network organization, modular corporation, virtual corporation, horizontal corporation, and boundaryless organization all vie to capture the essence of these new phenomena. $^{76}$ Stated simply, Baker argues that "[i]n theory, a network organization is integrated across formal boundaries; interpersonal ties of all types are formed without respect to vertical, horizontal, or spatial

73. See generally Michael E. Porter, The Competitive Advantage of Nations (1990); MiCHAEL E. PORTER, COMPETITION IN GLOBAL INDUSTRIES 18 (1986).

74. See Geert Duysters \& John Hagedoorn, Internationalization of Corporate Technology Through Strategic Partnering: An Empirical Investigation, 25 RES. POL'Y 1 (1996) (discussing technological innovations); Janet Y. Murray et al., Strategic and Financial Performance Implications of Global Sourcing Strategy: A Contingency Analysis, 26 J. INT'L BUS. STUD. 181 (1995). For an empirical look at global sourcing and research and development effects, respectively, see Yao-Su Hu, The International Transferability of the Firm's Advantages, CAL. MGMT. REV., Summer 1995, at 73 (discussing transferability and competition in broad terms); HIRSCH, supra note 39 (examining career management issues in the new economy).

75. See, e.g., JAy R. Galbraith, Organization Design (1977); Oliver E. Williamson, MARKETS AND HIERARCHIES: ANALYSIS AND ANTITRUST IMPLICATIONS (1975).

76. For usage of these terms, see infra notes 77-85 and accompanying text. 
differentiation."77 While this definition succinctly captures the boundaryless aspect of organizing within and across firms, a complete definition must also note that network organizations "rely more on market mechanisms than on administrative processes to manage resource flows." ${ }^{\text {,78 }}$ Taken together, a network organization is marked by a dual sense of cooperation that transcends boundaries-both intra- and interfirm boundaries-and market-oriented competition among groups defined by these boundaries. The term "coopetition" has been used to describe this mode of organizing. ${ }^{79}$ A key point, and often a point of confusion, is that such co-opetition in the network organization defines both intrafirm and interfirm dynamics.

The intrafirm network structure can be seen both as an extension of Jay Galbraith's discussion of integration mechanisms ${ }^{80}$ and as an elaboration of contingency theory. ${ }^{81}$ That is, in the spirit of creating an adaptive and flexible organization for the changing times, network firms are marked by a degree of vertical and horizontal integration that ignores boundaries to communication induced by a logic of functional, product, or professional differentiation. ${ }^{82}$ Descriptive and prescriptive accounts of how to develop and organize these new types of organizational forms can be found in the popular press, ${ }^{83}$ practitionerfocused journals, ${ }^{84}$ and in trade books. ${ }^{85}$

Discussions of network organizations from an interfirm perspective begin by acknowledging that these structures share aspects of both hierarchical and market governance arrangements. ${ }^{86}$ As Farok J. Contractor and Peter Lorange and Nitin Nohria and Carlos Garcia-Pont point out, these linkages can range from various equity-based joint venture agreements, to research and development or sourcing agreements, to patent licensing or distribution agreements,

77. Wayne E. Baker, The Network Organization in Theory and Practice, in NETWORKS AND ORGANIZATIONS: STRUCTURE, FORM, AND ACTION 397, 422 (Nitin Nohria \& Robert G. Eccles eds., 1992).

78. Raymond E. Miles \& Charles C. Snow, Fit, Failure, and the Hall of Fame: How COMPANIES SUCCEED OR FAIL 117 (1994).

79. See Adam M. Brandenburger \& Barry J. Nalebuff, Co-opetition 5 (1996).

80. See GALBRAITH, supra note 75 , at 243-62.

81. See Paul R. LaWrence \& Jay W. Lorsch, Organization And Environment: MANAGING DIFFERENTIATION AND INTEGRATION (1967).

82. See supra notes 77-81 and accompanying text.

83. See, e.g., John A. Byrne et al., The Virtual Corporation, Bus. WK., Feb. 8, 1993, at 98; Shawn Tully, The Modular Corporation, FORTUNE, Feb. 8, 1993, at 106.

84. See, e.g., Peter F. Drucker, The Coming of the New Organization, HARV. Bus. REV., Jan.-Feb. 1988, at 45 (discussing an "information-based organization"); Raymond E. Miles \& Charles C. Snow, Network Organizations: New Concepts for New Forms, CAL. MgMT. ReV., Spring 1986, at 62 (referring to this new organizational form as the "dynamic network firm").

85. See, e.g., Ron Ashkenas et Al., The Boundaryless Organization: Breaking the Chains of ORganizational STRUCTURE (1995); William H. DAVIDOW \& Michael S. Malone, THE VIRTUAL CORPORATION: STRUCTURING AND REVITALIZING THE CORPORATION FOR THE 21ST CENTURY (1992).

86. But see Walter W. Powell, Neither Market Nor Hierarchy: Network Forms of Organization, 12 Res. ORG. BeHAV. 295 (Barry M. Staw \& L.L. Cummings eds., 1990). 
among others. ${ }^{87}$ A number of scholars have chronicled the emergence of such linkages. ${ }^{88}$ Observing recent data on alliance formation in light of this past work, Ranjay Gulati observed that these data only confirmed what previous studies have reported-that there has been a "dramatic increase in interfirm strategic alliances." partnerships with greater than ten percent, but less than majority, ownership stakes in foreign enterprises, the data in Table 1 also provide evidence of the pace of cross-border alliance growth. ${ }^{90}$

5. Changes in the Regulatory Environment. Between the two World Wars, there was a flurry of regulatory activity in the United States relating to corporations. However, the primary focus of this regulatory activity was on capital providers to the firm. Perhaps the most notable development was the passage of the Securities Exchange Act of 1934, mandating greater transparency in, and disclosure of, corporate activity-and resulting in the creation of the Securities and Exchange Commission-with a view toward ensuring efficiency and fairness in the dealings of the corporation with its capital providers. ${ }^{91}$ Around this time, a set of regulations describing-and proscribing - the role of banking institutions in corporate activity was also enacted. $^{92}$ In the immediately following period, this regulatory focus on capital providers continued. ${ }^{93}$ To the extent there was any concern with non-capital provider constituencies, the consumer was the primary focus, as evidenced by

87. See, e.g., CoOperative Strategies in InTERnAtional Business (Farok J. Contractor \& Peter Lorange eds., 1988); Nitin Nohria \& Carlos Garcia-Pont, Global Strategic Linkages and Industry Structure, 12 STRATEGIC MGMT. J. 105, 111 (1991).

88. See generally KATHRYN RUDIE HARRIGAN, MANAGING FOR JOINT VENTURE SUCCESS (1986); KAREN J. HLADIK, INTERNATIONAL JOINT VENTURES: AN ECONOMIC ANALYSIS OF U.S.FOREIGN BUSINESS PARTNERSHIPS (1985); DAVID C. MOWERY, INTERNATIONAL COLlABORATIVE VentuRES In U.S. MANUfACTURING (David C. Mowery ed., 1988); Dorothy B. Christelow, International Joint Ventures: How Important Are They?, 23. COLUM. J. WORLD Bus., Summer 1987, at 7; M.W. Morris \& M. Hergert, Trends in International Cooperative Agreements, 22 COLUM. J. WORLD BUS., Summer 1987, at 15; Anant Sundaram \& N. Venkatraman, Organizational Forms, in RESEARCH In STRATEgic MANAGEMENT AND INFORMATION TECHNOlOGY (N. Venkatraman \& J. Henderson eds., 1999); COOPERATIVE STRATEGIES, supra note 87.

89. Ranjay Gulati, Does Familiarity Breed Trust? The Implications of Repeated Ties for Contractual Choice in Alliances, 38 ACAD. OF MGMT. J. 85, 85-112 (1995).

90. See 1997 ABSTRACT, supra note 52.

91. Securities Exchange Act of 1934, ch. 404, 48 Stat. 881 (codified as amended at 15 U.S.C. $\S \S 77$, 78 (1997)); Louis Loss \& Joel Seligman, 7 SeCurities Regulation 3448-66 (3d ed. 1991) (discussing foundational cases related to the duty to disclose). For cases that illustrate this point, see generally Diamond v. Oreamuno, 248 N.E.2d 910 (New York 1969); In re ORFA, 654 F. Supp. 1449 (D.N.J. 1987). But see Schein v. Chasen, 313 So. 2d 739 (Fla. 1975); Freeman v. Decio, 584 F.2d 186 (7th Cir. 1978).

92. See, e.g., McFadden Act of 1927, ch. 191, 44 Stat. 1224 (codified as amended in scattered sections of 12 U.S.C.); Glass-Steagall Act of 1933, ch. 89, 48 Stat. 162 (codified at 12 U.S.C. $\$ \S 347 a, 347 b$, 412 (1997)).

93. See, e.g., Investment Company Act of 1940, ch. 686, Title I, 54 Stat. 789 (codified as amended in scattered sections of 15 U.S.C. § 80a (1997)); Bank Holding Company Act of 1956, ch. 240, 70 Stat. 133 (codified as amended at 12 U.S.C. $\S \S 1841,1843$ (1997)). 
the passage of the Sherman ${ }^{94}$ and Clayton Acts ${ }^{95}$ dealing with antitrust issues and fairness in competition. It is equally important to note that during this period of the emergence and solidification of the era of corporate capitalism in the United States, there were few major federal laws addressing the concerns of other stakeholders, such as employees, communities, and the natural environment. ${ }^{96}$

In the 1960s, the focus on capital providers began to shift significantly. Regulatory efforts during this era became increasingly concerned about the corporate entity's impact on its various non-shareholder constituencies. ${ }^{97}$ For example, labor found protection in Title VII of the Civil Rights Act ${ }^{98}$ the Age Discrimination in Employment Act, ${ }^{99}$ the Occupational Safety Act, ${ }^{100}$ the Employee Retirement Income Security Act, ${ }^{101}$ the Employment Opportunities for Disabled Americans Act, ${ }^{102}$ and the Employee Polygraph Protection Act. ${ }^{103}$ This protection continued into the 1990s with adoption of both the Family and Medical Leave Act ${ }^{104}$ and the Americans with Disabilities Act. ${ }^{105}$

Similarly, consumers of corporate products and services received a number of additional protections in this time period. Major consumer-oriented legislation adopted in the 1960 s includes the federal Truth-in-Lending legislation ${ }^{106}$ and the 1962 Uniform Commercial Code, including its product-warranty provisions adopted by forty-nine states. ${ }^{107}$ Courts also began abolishing contributory negligence as a defense in product liability cases. ${ }^{108}$ Similar consumer protec(1997))

94. Sherman Anti-Trust Act, ch. 647, 26 Stat. 209 (1890) (codified as amended at 15 U.S.C. §§ 1-7

95. Clayton Act, ch. 323, 38 Stat. 730 (1914) (codified as amended at 15 U.S.C. $§ ~ 12-27$ (1997)).

96. One of the few such laws passed in this era was the Federal Trade Commission Act of 1914, ch. 311, 38 Stat. 717 (1914) (codified at 15 U.S.C. $\$ 41-57$ (1997)).

97. See infra notes 98-105.

98. Civil Rights Act of 1964, Pub. L. 88-352, 78 Stat. 241 (codified as amended at 28 U.S.C. $§ 1447$ and scattered sections of 42 U.S.C. (1997)).

99. Age Discrimination in Employment Act of 1967, Pub. L. 90-202, 81 Stat. 602 (codified as amended at 29 U.S.C. $\$ \S 621-634$ (1997)).

100. Occupational Safety and Health Act of 1970, Pub. L. 91-596, 84 Stat. 1590 (codified as amended in scattered sections of 5, 15, 18, 29, 42, 49 U.S.C. (1997)).

101. Employee Retirement Income Security Act of 1974, Pub. L. 93-406, 88 Stat. 829 (codified as amended in scattered sections of 5, 18, 26, 29, 31, 42 U.S.C. (1997)).

102. Employment Opportunities for Disabled Americans Act, Pub. L. 99-643, 100 Stat. 3574 (1986) (codified as amended at 42 U.S.C. $\S \$ 1305$ note, 1382-1383, 1396 (1997)).

103. Employee Polygraph Protection Act of 1988, Pub. L. 100-347, 102 Stat. 646 (codified as amended at 29 U.S.C. $\$ \$ 2001-2009$ (1997)).

104. Family and Medical Leave Act of 1993, Pub. L. 103-3, 107 Stat. 6 (codified as amended in scattered sections of 2, 5, 29 U.S.C. (1997)).

105. Americans with Disabilities Act of 1990, Pub. L. 101-336, 104 Stat. 327 (codified as amended at 29 U.S.C. $\$ 706$ and scattered sections of 42 U.S.C. (1997)).

106. Truth-in-Lending Act, Pub. L. 90-321, Title I, 82 Stat. 146 (1968) (codified as amended in scattered sections of 15 U.S.C. (1997)).

107. U.C.C. $\S \S 2-312$ to 2-318 (1962) (setting forth product-warranty provisions that have been adopted by 49 states).

108. For examples of courts abolishing contributory negligence as a defense in product liability cases, see generally Jimenez v. Sears, Roebuck \& Co., 904 P.2d 861, 864-65 (Ariz. 1995); Norrie v. Heil Co., 203 Conn. 594, 599-602 (1987); Robinson v. B.F. Goodrich Tire Co., 664 A.2d 616, 618 (Pa. Super. 
tions arose in the 1970s with the adoption of the Fair Credit Reporting Act, ${ }^{109}$ the Consumer Product Safety Act, ${ }^{110}$ the Equal Credit Opportunity Act, ${ }^{111}$ the Fair Credit Billing Act, ${ }^{112}$ the Magnuson-Moss Warranty Act, ${ }^{113}$ and the Fair Debt Collection Practices Act, ${ }^{114}$ and the states' acceptance of Restatement (Second) of Torts, Section 402B, providing consumers with recovery mechanisms for misrepresentation. ${ }^{115}$ Truth-in-lending reform legislation was adopted in the 1980s and 1990s. ${ }^{116}$

Similarly, society became increasingly concerned about corporations' impact on the natural environment. The 1960s brought about the adoption of the Clean Water Restoration Act $^{117}$ and amendments to the Clean Air Act. ${ }^{118}$ Environmental legislation in the 1970s included the National Environmental Policy Act, ${ }^{119}$ amendments to the Clean Air Act, ${ }^{120}$ the Resource Conservation and Recovery Act, ${ }^{121}$ the Federal Water Pollution Control Act, ${ }^{122}$ the Clean Water

Ct. 1995); General Motors Corp. v. Saenz, 966 S.W.2d 545, 553-57 (Tex. App. 1997) (abolishing contributory negligence as a defense in strict product liability cases unless plaintiff has assumed the risk).

109. Fair Credit Reporting Act, Pub. L. 91-508, Title IV, § 601, 84 Stat. 1128 (1970) (codified as amended at 15 U.S.C. $\$ 1681$ (1997)).

110. Consumer Product Safety Act, Pub. L. 92-573, 86 Stat. 1207 (1972) (codified as amended at 5 U.S.C. $\$ \$ 5314-5315,15$ U.S.C. $\$ \$ 2051-2084(1997))$.

111. Equal Credit Opportunity Act, Pub. L. 93-495, Title V, 88 Stat. 1521 (1974) (codified as amended at 15 U.S.C. § 1691 (1997)).

112. Fair Credit Billing Act, Pub. L. 93-495, Title III, 88 Stat 1511 (1974) (codified as amended in scattered sections of 15 U.S.C. (1997)).

113. Magnuson-Moss Warranty-Federal Trade Commission Improvement Act, Pub. L. 93-637, 88 Stat. 2183 (1975) (codified as amended in scattered sections of 15 U.S.C. (1997)).

114. Fair Debt Collection Practices Act, Pub. L. 95-109, 91 Stat. 874 (1977) (codified as amended at 15 U.S.C. $\S \S 1601$ note, 1692 (1997)).

115. See, e.g., Baroldy v. Ortho Pharm. Corp. 760 P.2d 574, 577 (Ariz. Ct. App. 1988); Westlye v. Look Sports, Inc., 22 Cal. Rptr. 2d 781, 801-02 (1993); Ziegler v. Kawasaki Heavy Indus., 539 A.2d 701, 704 (Md. Ct. Spec. App. 1988).

116. See Truth in Lending Simplification \& Reform Act, Pub. L. No. 96-221, Title VI, 94 Stat. 168 (1980) (codified as amended in scattered sections of 15 U.S.C. (1997)); Truth-in-Lending Act Amendments of 1995, Pub. L. No. 104-29, 109 Stat. 271 (codified as amended in scattered sections of 15 U.S.C. (1997)).

117. Clean Water Restoration Act of 1966, Pub. L. 89-753, 80 Stat. 1246 (codified as amended at 33 U.S.C. $\S ~ 431-437,466$ (1997)).

118. Clean Air Act, Pub. L. 86-365, 73 Stat. 646 (1959) (codified as amended at 42 U.S.C. § 1857(d), (g) (1997)).

119. National Environmental Policy Act of 1969, Pub. L. 91-190, 83 Stat. 852 (1969); Pub. L. 94-52, 89 Stat. 258 (1975) (codified as amended at 42 U.S.C. $\S \S 4321,4331-4335,4341-4347$ (1997)).

120. Clean Air Amendments of 1970, Pub. L. 91-604, 84 Stat. 1676 (codified as amended at 42 U.S.C. $\S \S 215$ note, 1857, 49 U.S.C. app. $\S \S 1421,1430,50$ U.S.C. app. $§ 456$ (1997)), Clean Air Act Amendments of 1977, Pub. L. 95-95, 91 Stat. 685 (codified as amended in scattered sections of 15 U.S.C. (1997)).

121. Resource Conservation and Recovery Act of 1976, Pub. L. 94-580, 90 Stat. 2795 (codified as amended in scattered sections of 42 U.S.C. (1997)).

122. Federal Water Pollution Control Act Amendments of 1972, Pub. L. 92-500, 86 Stat. 816 (codified as amended at 12 U.S.C. $§ 24 ; 15$ U.S.C. $\S \S 633,636 ; 31$ U.S.C. $§ 1305$; and scattered sections of 33 U.S.C. (1997)). 
Act, ${ }^{123}$ the Safe Drinking Water Act, ${ }^{124}$ and the Toxic Substances Control Act. ${ }^{125}$ Further environmental legislation adopted in the 1980s and 1990s included the Comprehensive Environmental Response, Compensation, and Liability Act, also known as the Superfund legislation, ${ }^{126}$ the Pollution Prevention Act, ${ }^{127}$ and the Oil Pollution Act. ${ }^{128}$

At the same time that corporations were being increasingly regulated, both directly and indirectly, the 1970s witnessed an affirmation of the corporation's separate-entity status in society. That is, the courts began to view the corporation as though it were a natural person and began to afford it certain constitutional protections. In United States v. Martin Linen Supply Co., ${ }^{129}$ for example, the U.S. Supreme Court extended Fifth Amendment protection to the corporation. In Marshall v. Barlow's Inc., ${ }^{130}$ the U.S. Supreme Court applied the Fourth Amendment to the corporation, and in First Nat'l Bank of Boston v. Bellotti, ${ }^{131}$ First Amendment protection was granted to corporate speech.

Perhaps not surprisingly, because the law was increasingly imposing a greater mandate on managers to deal with the concerns of non-shareholder constituencies, firms were also granted greater latitude in directors' control. In addition to the constitutional rights granted to corporations, there was a trend toward relaxing the liability of corporate directors. In 1986, the Delaware legislature adopted title 8, section 102(b)(7) of the Delaware Code Annotated, permitting corporations to amend their charters to limit or eliminate directors' monetary liability for non-intentional breach of the duty of care to the corporation and its shareholders. ${ }^{132}$ More than forty states have followed Delaware's lead and adopted similar exculpatory legislation. ${ }^{133}$

123. Clean Water Act of 1977, Pub. L. 95-217, 91 Stat. 1566 (codified as amended in scattered sections of 33 U.S.C. (1997)).

124. Safe Drinking Water Act, Pub. L. 93-523, 88 Stat. 1660 (1974) (codified as amended at 21 U.S.C. $\S 349$, 42 U.S.C. $\S \S 201,300$ (1997)).

125. Toxic Substances Control Act, Pub. L. 94-469, 90 Stat. 2003 (1976) (codified as amended at 15 U.S.C. $\S 2601-2629$ (1997)).

126. Comprehensive Environmental Response, Compensation, and Liability Act of 1980, Pub. L. 96-510, 94 Stat. 2767 (codified as amended in scattered sections of 42 U.S.C. (1997)).

127. Pollution Prevention Act of 1990, Pub. L. 101-508, Title VI [Subtitle G], 104 Stat. 1388-321 (codified as amended at 42 U.S.C. $§ \$ 13101,13102-13109$ (1997)).

128. Oil Pollution Act of 1990, Pub. L. 101-380, 104 Stat. 484 (codified as amended in scattered sections of 33 U.S.C. (1997)).

129. See 430 U.S. 564 (1976).

130. See 436 U.S. $307,311-15$ (1978).

131. See 435 U.S. 765, 775-86, reh'g denied, 438 U.S. 907 (1978).

132. See Del. Code AnN. tit. 8, § 102(b)(7) (Supp. 1998); see also Bradley \& Schipani, supra note 15 , at $42-44$.

133. See Ala. Code $\S 10-2 B-2.02(b)(3)$ (1994); Alaska Stat. $\S 10.06 .210(1)(\mathrm{N})$ (Michie 1998); ARIZ. ReV. StAT. § 10-202(B)(1) (Supp. 1998); ARK. CODE ANN. § 4-27-202(B)(3) (Michie 1996); CAl. CORP. CODE § 204(a)(10) (West 1990); Colo. Rev. STAT. § 7-108-402 (1998); CONN. GEN. STAT. § 33-636(b)(4) (1997); FLA. STAT. ch. 607.0831 (Supp. 1999); GA. CODE ANN. § 14-2-202(b)(4) (Supp. 1998); HAW. REV. STAT. § 415-48.5 (1997); IDAHO CODE § 30-1-202(2)(d) (Supp. 1998); 805 Ill. COMP. STAT. 5/2.10(b)(3) (West Supp. 1998); IND. CODE ANN. § 23-1-35-1(e) (Michie 1995); IOWA CODE ANN. § 490.832 (West 1991); KAN. STAT. ANN. § 17-6002(b)(8) (1995); KY. ReV. STAT. AnN. § 271B.2-020(2)(d) (Banks-Baldwin 1989); LA. ReV. STAT. AnN. § 12:24(C)(4) (West Supp. 1999); MD. CODE ANN., CORPS. \& Ass’NS §§ 2-405.2 (Supp. 1998); MAss. GEN. LAws ch. 156B, § 
Similarly, a majority of states now statutorily permit directors to consider the interests of non-shareholder constituencies in making managerial decisions. ${ }^{134}$ These statutes provide directors with discretion to consider the interests of other constituencies, such as labor, customers, suppliers, and the community. For example, the New York statute provides the following:

In taking action, including, without limitation, action which may involve or relate to a change or potential change in the control of the corporation, a director shall be entitled to consider, without limitation, (1) both the long-term and the short-term interests of the corporation and its stakeholders and (2) the effects that the corporation's actions may have in the short-term or in the long-term upon any of the following:

(i) the prospects for potential growth, development, productivity and profitability of the corporation;

13(b)(11/2) (1996); MiCH. COMP. LAws § 450.1209(1)(c) (Supp. 1998); MINN. STAT. § 302A.251(4) (Supp. 1999); Miss. CodE ANN. § 79-4-2.02(b)(4) (1996); MONT. CODE ANN. § 35-1-216(2)(d) (1997); NEB. REV. STAT. § 21-2018(2)(d) (1995); NEV. REV. STAT. § 78.037(1) (1994); N.H. REV. STAT. ANN. § 292-2 (Supp. 1996); N.J. STAT. ANN. § 14A:2-7(3) (West 1998); N.M. STAT. ANN. § 53-12-2(E) (Michie 1998); N.Y. BUS. CORP. LAW § 402(b) (McKinney Supp. 1999); N.C. GEN. STAT. § 55-202(b)(3) (1997); N.D. CENT. CODE § 10-19.1-50(5) (Supp. 1997); OKLA. STAT. tit. 18, § 1006(B)(7) (1999); OR. REV. STAT. § 60.047(2)(d) (1988); 15 PA. CONS. STAT. § 1713 (1995); R.I. GEN. LAws § 71.1-48(a)(6) (1992); S.C. CodE ANN. § 33-2-102(e) (Law. Co-op. 1990); S.D. CodifIEd LAws § 47-258.8 (Michie 1991); Tenn. Code AnN. § 48-12-102(b)(3) (Supp. 1994); TeX. Rev. Civ. Stat. AnN. art. 1302-7.06(B) (West 1997); UTAH CODE ANN. § 7-7-3.1 (Supp. 1998); VT. STAT. ANN. tit. 11A, § 2.02(b)(4) (1997); VA. CODE ANN. § 13.1-692.1(A)(2) (Michie 1993) (capping the liability at the greater of $\$ 100,000$ or the amount of cash compensation received from the corporation during the last 12 months); WASH. REV. CODE § 23B.08.320 (1994); WIS. STAT. § 180.0828 (1992); WYO. STAT. ANN. $\S 17-16-202$ (b)(iv) (Michie 1997); see also Bradley \& Schipani supra note 15, at $72 \mathrm{n} .374$.

134. The following statutes permit directors to consider the interests of non-shareholder constituencies in any appropriate context: CONN. GEN. STAT. § 33-756(d) (1997) (mandating consideration of non-shareholder constituencies); FLA. STAT. ch. 607.0830(3) (Supp. 1999); GA. CODE ANN. § 14-2202(b)(5) (Supp. 1998); HAW. REV. STAT. § 415-35(b) (1997); IDAHO CODE § 30-1702 (1996); 805 ILL. COMP. STAT. 5/8.85 (West 1993); IND. CODE § 23-1-35-1(d) (1995); IOWA CODE § 491.101B (1991); Me. ReV. Stat. ANN. tit. 13-A, § 716 (West Supp. 1998); MASs. Gen. LAws ANN. ch. 156B, § 65 (West Supp. 1998); MinN. STAT. § 302A.251(5) (Supp. 1999); Miss. CodE ANN. § 79-4-8.30(d) (1998); NeV. ReV. StAT. § 78.138(3) (1994); N.J. StAT. ANN. § 14A:6-1(2) (West Supp. 1998); N.M. STAT. ANN. § 53-11-35(D) (Michie 1997); N.Y. BuS. CORP. LAW § 717(b) (McKinney Supp. 1999); N.D. CENT. CODE § 10-19.1-50(6) (Supp. 1997); OHIO REV. CODE ANN. § 1701.59(E) (Anderson 1993); OR. REV. StAT. § 60.357(5) (Supp. 1996); 15 PA. CONS. STAT. § 515 (1995); Wis. STAT. § 180.0827 (1992); WYO. STAT. ANN. § 17-16-830(e) (Michie 1997). The following statutes permit directors to consider the interests of non-shareholder constituencies in the context of transactions for corporate control: ALA. CODE § 10-2B-11.03(c) (1994); ARIZ. REV. STAT. §§ 10-2702, 10-1202(c) (1996) (sale of assets); ARK. CODE ANN. § 4-27-1202(C) (Michie 1996) (sale of assets); COLO. REV. STAT. §§ 7-106105(7) (reverse splitting of shares), 7-111-103(3), 7-114-102(3) (1998) (authorization of dissolution after issuance of shares); KY. REV. STAT. ANN. \$§ 271B.11-030(2)(b), 271B.12-020(3) (Banks-Baldwin 1989) (sale of assets); LA. REV. STAT. ANN. § 12:92(G) (West 1994); Mo. ANN. STAT. § 351.347 (West 1991); MONT. CODE ANN. §§ 35-1-815(3), 35-1-823(3) (1997) (sale of assets); N.H. REV. STAT. ANN. §§ 293-A:11.03(c), 293-A:12.02(c) (Supp. 1996) (sale of assets); N.C. GEN. STAT. §§ 55-11-03(c), 55-12-02(c) (1990) (sale of assets); R.I. GEN. LAws § 7-5.2-8 (1992); S.C. CODE ANN. §§ 33-11-103(c), 33-12-102(c) (Law. Co-op. 1990) (sale of assets); S.D. CODIFIED LAWs § 47-33-4 (Michie 1991); TENN. CODE AnN. § 48-103-204 (1995); TeX. Bus. CORP. ACT ANN. art. 5.03 (West Supp. 1999); UTAH CODE ANN. § 16-10a-1103(3) (1995); VT. STAT. ANN. tit. 11A, §§ 11.03(c), 12.02(c) (1997) (sale of assets); VA. CODE ANN. § 13.1-718(C) (Michie 1993); VA. CODE AnN. § 13.1-724(C) (Michie Supp. 1998) (sale of assets); WASH. REV. CODE $\S \S 23$ B.11.030(3), 23B.12.020(3) (1994) (sale of assets). The following states and territories do not have specific legislation regarding consideration of the interests of non-shareholder constituencies: Alaska, California, Delaware, District of Columbia, Kansas, Maryland, Michigan, Nebraska, Oklahoma, Puerto Rico, Virgin Islands, and West Virginia. 
(ii) the corporation's current employees;

(iii) the corporation's retired employees and other beneficiaries receiving or entitled to receive retirement, welfare or similar benefits from or pursuant to any plan sponsored, or agreement entered into, by the corporation;

(iv) the corporation's customers and creditors; and

(v) the ability of the corporation to provide, as a going concern, goods, services, employment opportunities and employment benefits and otherwise to contribute to the communities in which it does business.

Nothing in this paragraph shall create any duties owed by any director to any person or entity to consider or afford any particular weight to any of the foregoing or abrogate any duty of the directors, either statutory or recognized by common law or court decisions. ${ }^{135}$

On the one hand, granting management further discretion in decisionmaking authority is consistent with the societal trends requiring the corporation to be more accountable to non-shareholder constituencies. That is, to be sensitive to the impact of the firm on such stakeholders as labor, customers, and the local community, it may be necessary formally to allow managers the discretion in their decisionmaking authority to consider these interests. On the other hand, such discretion holds the potential for managerial abuse. Rather than balance the interests of all constituencies affected by the corporate form, managers may be tempted by this discretion to pursue their self-interest at the expense of others' interests. Responsibility to all stakeholder groups may effectively mean accountability to none.

In summary, while early regulatory activity concerned itself with the protection of the rights of capital providers to the firm-notably equityholders, presumably because the relationship between the firm and bondholders has always been, and continues to be, governed by contract law-the legislative thrust at both the federal and state levels during the more recent past has been to strengthen the hands of non-shareholder constituencies. ${ }^{136}$

\section{B. The Implications of Change for Corporate Governance}

If corporate governance theory requires consideration of how the various constituencies that define the business enterprise serve and are served by the corporation, then the changes considered above raise significant questions about our understanding of corporate governance. After identifying these governance challenges, this article will appraise governance scholarship and its ability to address these issues.

Knowledge-based, post-industrial work raises confusing control issues. William G. Ouchi's and Kathleen M. Eisenhardt's consideration of clan-based

135. N.Y. BUS. CORP. LAW $\S 717(b)$ (McKinney Supp. 1999).

136. But see Eric W. Orts, Beyond Shareholders: Interpreting Corporate Constituency Statutes, 61 GEO. WASH. L. REV., Nov. 1992, at 14, 91-92 (1992) (arguing that constituency statutes "simply ratify preexisting corporate law"; they do not "redefine corporate law to produce social change"). 
control pointed this out years ago. ${ }^{137}$ If a manager can neither measure a subordinate's work with reliable validity nor specify the steps to accomplish the desired outcomes, then process-and output-oriented control systems imported from the days of the Industrial Revolution will be suboptimal, if not a counterproductive failure. $^{138}$

The proliferation of new financial products, the globalization of capital markets, and the rise of the institutional investor raise at least three implications for corporate governance. The increase in the number of sources of capital makes it very difficult to assess investment risk accurately. This problem is compounded by the global nature of the capital market. Cross-border disclosure rules and regulations are underdeveloped. Because disclosure rules are not standardized worldwide, an investor must make complex risk assessments with limited information. In addition, the concentration of wealth in the hands of pension and mutual fund managers ${ }^{139}$ challenges the control assumptions that lie behind the traditional principal-agent theory that has oriented much of the understanding of corporate governance over the years. ${ }^{140}$ As Daniel J.H. Greenwood recently pointed out, it is very difficult to know who a firm's owners are today, much less their interests. ${ }^{141}$ Institutional owners who directly interact with corporate managers are in reality agents of a diffuse group of fund shareholders who may know or care little about the operations of any particular company. Owners now must be seen as investors; accordingly, agency relationships are more complex. If investment managers are agents for the firm's investors, then those investors must rely on an agent and the agent of an agent (that is, the investment manager and the corporate manager) to deploy their capital in a productive manner. This potentially troubling development will be referred to as a cascading agency problem.

Globalization of product-market competition serves as an exacting form of firm discipline. As Michael Jensen, Frank Easterbrook, and others have pointed out, if a firm cannot sell a product at a profit in the marketplace, that is unless it is fit, it will not survive. ${ }^{142}$ This form of market discipline is perhaps

137. See Kathleen M. Eisenhardt, Control: Organizational and Economic Approaches, 31 MGMT. SCI. 134 (1985); William G. Ouchi, Markets, Bureaucracies, and Clans, 25 ADMIN. SCI. Q. 129 (1980); Ouchi, supra note 28.

138. See id.

139. See Michael Useem, Investor Capitalism: How Money Managers are Changing THE FACE OF CORPORATE AMERICA 25-33 (1996); John M. Conley \& William M. O'Barr, The Culture of Capital: An Anthropological Investigation of Institutional Investment, 70 N.C. L. REV. 823, 823 (1992) (pension funds); Lester B. Snyder \& Marianne Gallegos, Redefining the Role of the Federal Income Tax: Taking the Tax Law "Private" Through the Flat Tax and Other Consumption Taxes, 13 AM. J. TAX POL'Y 1, 19-22 (1996).

140. See A.A. Berle, Jr. \& Gardiner C. Means, The Modern Corporation \& Private PROPERTY 119 (Transaction Publishers 1991) (1932); E.C. Lashbrooke, Jr., Internal Revenue Code Section 170 and the Great Corporate Giveaway, 22 PAC. L.J. 221, 230-31 (1991); Thomas S. Ulen, The Coasean Firm in Law and Economics, 18 J. CORP. L. 301, 312-18 (1993).

141. See Daniel J.H. Greenwood Fictional Shareholders: For Whom are Corporate Managers Trustees, Revisited, 69 S. CAL. L. REV. 1021, 1086-93 (1996).

142. See generally Jensen, supra note 13. For a general discussion of law and market efficiency, see Frank H. Easterbrook, International Corporate Differences: Markets or Law?, J. APPLIED CORP. FIN., 
the most important assurance that capital will be supplied at the lowest cost for firms in market economies. Concurrent with product-market globalization, the market for physical capital, the market for technology, and to a certain extent, the market for corporate control all have become globalized as well. In the process, both the internal management of the various parts of the firm's value chain and the external management of the firm's shareholder/stakeholder interests involve the imperative of cross-border coordination and control. However, while MNEs have nudged economic activity toward borderlessness, their operations span sovereign borders in a world in which the territorial authority of the nation-state is paramount. Cross-border liability and bankruptcy rules, antitrust laws, contract enforcement, and dispute resolution standards and protocols are all problematic in a setting in which the principle of territoriality is the governing norm. ${ }^{143}$ Thus, as the contemporary conduct of the corporation is considered, it is important to recognize that there is a void at the intersection of sovereign boundaries that is very difficult to manage and control. ${ }^{144}$

Network organizations are valuable for their flexibility and responsiveness to complex and uncertain competitive environments. For example, suppliers in some situations can provide a higher-quality and lower-cost product even when it is the product of a transaction-specific asset. ${ }^{145}$ Moreover, cooperative relationships can be established between fierce competitors. ${ }^{146}$ With the rise of inter- and intrafirm agreements of all types, it is difficult to know where the boundary of one firm ends and another begins. These complex relationships make it difficult for an outsider-be it an investor, regulator, or director-to discern a firm's operating characteristics. Legally, the body of corporate law that pertains to a discrete firm may become limited in its applicability, or even inapplicable, when the firm is considered as an aggregation of all of these network relationships. If the latter organization is defined more broadly as an enterprise rather than a firm, it is questionable whether the understanding of

Winter 1997, at 23, 28. Interestingly, the phrase "survival of the fittest" was coined by Herbert Spencer. See Herbert SPENCER, 1 THE PRINCIPles of Biology 457 (1897). Herbert Spencer was a 19th Century English social philosopher and the sub-editor of The Economist, who used the term to describe both the process of a competitive market and the process of natural selection in the evolution of biological species. See Darwin Revisited, ECONOMIST, Aug. 30, 1997, at 12.

143. See generally Kose John et al., Cross-Border Liability of Multinational Enterprises, Border Taxes, and Capital Structure, Fin. MGMT., Winter 1991, at 54; James S. McNeill, Comment, Extraterritorial Antitrust Jurisdiction: Continuing the Confusion in Policy, Law, and Jurisdiction, 28 CAL. W. INT'L L.J. 425 (1998); Steven L. Snell, Controlling Restrictive Business Practices in Global Markets: Reflections on the Concepts of Sovereignty, Fairness, and Comity, 33 STAN. J. INT'L L. 215 (1997).

144. See Anant K. Sundaram \& J. Stewart Black, The Environment and Internal Organization of Multinational Enterprises, 17 ACAD. MGMT. REV. 729, 735-38 (1992).

145. See Toshiniro Nishiguchi, Strategic Industrial Sourcing: The Japanese AdVANTAGE 213-15 (1994).

146. See Greg Young et al., “Austrian” and Industrial Organization Perspectives on Firm-Level Competitive Activity and Performance, 7 ORG. SCI. 243 (1996); BRANDENBURGER \& NALEBUfF, supra note 79 , at 27. 
firm-level corporate governance and control developed in an earlier era will apply to the governance of enterprises. ${ }^{147}$

The move toward greater regulatory accountability and managerial discretion mobilizes shareholders and forces directors to address the discretionary paradox identified above. ${ }^{148}$ Even if self-dealing temptations can be resisted or controlled, it is not clear how managers and directors should carry out their social responsibilities to their various stakeholders when their interests do not coincide. ${ }^{149}$ The rise of statutes that address constituencies other than capital providers may seriously erode the effectiveness of the market for corporate control. In other words, the corporate governance challenges identified here may have to be addressed in a regulatory setting in which the disciplining role of the takeover market might be increasingly under strain. Table 2 summarizes the five broad changes in the conduct of the corporation that have been identified-changes in the nature of work, capital markets, product-market competition, organizational forms, and regulatory environment-and their attendant governance challenges. The key question is whether the current theories and practices of corporate governance can accommodate and effectively deal with these challenges. This question will be addressed next.

147. See generally Phillip I. Blumberg, The Multinational Challenge to Corporation LAW: THE SEARCH FOR A NEW CORPORATE PERSONALITY 231-53 (1993) (proposing enterprise law for MNEs); REGUlATING CORPORATE GROUPS IN EUROPE (David Sugarman \& Gunther Teubner eds., 1990); Cindy A. Schipani, Infiltration of Enterprise Theory Into Environmental Jurisprudence, 22 J. CORP. L. 599 (1997).

148. See John C. Coffee, Jr., Liquidity Versus Control: The Institutional Investor as Corporate Monitor, 91 COLUM. L. REV. 1277, 1286-89 (1991).

149. See Frank H. EASTERbrook \& DANiEl R. Fischel, The ECONOMic Structure of CORPORATE LAW 110-17 (1991) [hereinafter EASTERBROOK \& FisCHEL, ECONOMIC STRUCTURE]; Frank H. Easterbrook \& Daniel R. Fischel, The Proper Role of a Target's Management in Responding to a Tender Offer, 94 HARV. L. REV. 1161, 1190-92 (1981). 
TABLE 2

CHANGE AND ITS Challenges to CORPORATE GOVERnANCE

\begin{tabular}{|c|c|c|}
\hline & $\begin{array}{c}\text { The Nature of the Change and } \\
\text { its Attributes }\end{array}$ & $\begin{array}{c}\text { Implications for Corporate } \\
\text { Governance }\end{array}$ \\
\hline Work & Knowledge based & $\begin{array}{l}\text { Problematic Managerial con- } \\
\text { trol }\end{array}$ \\
\hline \multirow[t]{3}{*}{ Capital Market } & Product proliferation & $\begin{array}{l}\text { Difficulties in assessing oper- } \\
\text { ating and business risk }\end{array}$ \\
\hline & Globalization & $\begin{array}{l}\text { Undeveloped cross-border } \\
\text { disclosure and regulation }\end{array}$ \\
\hline & Institutional investors & Cascading agency problems \\
\hline $\begin{array}{l}\text { Product-Market } \\
\text { Competition }\end{array}$ & Globalization & $\begin{array}{l}\text { Regulatory and enforcement } \\
\text { voids at the intersection of } \\
\text { sovereign boundaries }\end{array}$ \\
\hline Organizational Forms & Network forms & $\begin{array}{l}\text { Enterprises with fuzzy } \\
\text { boundaries and opaque oper- } \\
\text { ating characteristics }\end{array}$ \\
\hline \multirow[t]{2}{*}{$\begin{array}{l}\text { Regulatory Environ- } \\
\text { ment }\end{array}$} & Regulatory accountability & $\begin{array}{l}\text { Accountability-discretion } \\
\text { paradox }\end{array}$ \\
\hline & Managerial discretion & $\begin{array}{l}\text { Need for assumption of multi- } \\
\text { fiduciary responsibilities }\end{array}$ \\
\hline
\end{tabular}

III

\section{CONTEMPORARY CORPORATE GOVERNANCE SCHOLARSHIP}

With these changes underway, it is not surprising that scholarly interest in corporate governance has flourished in recent years. This section will review this work and examine whether it provides sufficient guidance as to how existing governance mechanisms will be able to cope with the changes documented above.

\section{A. Theories of Corporate Governance}

The kinds of challenges identified above cut to the heart of our understanding of the firm and the regulation of economic activity. These challenges implicate the management of a firm (for example, the control of post-industrial work and enacting a multifiduciary role), the control of a firm (for example, 
cascading agency problems, the accountability-discretion paradox, and opaque operating and risk assessments), and the institutional infrastructure that enables economic exchanges (for example, cross-border disclosure, regulation and contracting norms, as well as the market for corporate control). They also prompt a reconsideration of the first principles in understanding the firm, its role in society, and how it is to be controlled.

Stripped of their complexities, the debates in much of the scholarship on corporate governance can be distilled to one fundamental issue: whether the corporation should be viewed as a "nexus of contracts," negotiated among selfinterested individuals or as a "legal entity," with rights and responsibilities as a natural person. The debate concerns the best way to control the inherent conflict of interests among the corporation's stakeholders, most notably the conflict of interest between corporate managers and stockholders that arises from the separation of ownership and control in the large-scale, public corporation. So-called contractarians view the corporation as a nexus of contracts with no separate entity status of its own. ${ }^{150}$ Rather than advocate the imposition of legal constraints on the behavior of corporate managers, they prefer to rely on voluntary contracting and market forces to align the interests of managers and stockholders. In contrast, communitarians view the corporation as a separate entity with rights and responsibilities as a natural person. ${ }^{151}$ Communitarians argue that liability rules and judicial review are necessary to constrain the behavior of corporate managers. Without legal constraints, it is feared that management will be accountable neither to stockholders nor to society in general. ${ }^{152}$

These two views of the nature of the firm generate drastically different implications for public policy. If, on the one hand, corporations are viewed as a nexus of contracts, public policy should facilitate contracting among selfinterested individuals. By this view, judicial or legislative constraints are impediments to this contracting process and disadvantage all corporate stakeholders. On the other hand, if the corporation is viewed as a separate entity, capable of doing both harm and good, then its activities, like those of a natural person, must be held in check by legal rules and judicial review. ${ }^{153}$ Because this debate is quite basic to understanding corporate governance and leads to very different public policy proscriptions, the theoretical foundations of each position will be reviewed, noting their implications for governance practice, and then a critique of each view will be sketched.

150. See infra notes $154-161$ and accompanying text.

151. See infra notes 182-194 and accompanying text.

152. See Victor Brudney, Corporate Governance, Agency Costs, and the Rhetoric of Contract, 85 COLuM. L. REV. 1403, 1409 (1985); William L. Cary, Federalism and Corporate Law: Reflections Upon Delaware, 83 YALE L. J. 663, 663-72 (1974).

153. See Bradley \& Schipani, supra note 15 , at 5. 


\section{Contractarianism.}

a. Contractarianism Defined. Building on well-established principles of neoclassical economics and finance, the contractarian view focuses on the contractual relations that exist among the firm's so-called stakeholders. This theory of the corporation, which is prevalent in the law and economics literature, derives from the theory of the firm, a theory based on the early work of Ronald Coase, who argued that firms exist to minimize the costs of trading in external markets. ${ }^{154}$ Coase was the first to point out that trading in markets is costly, and that often these costs can be reduced by creating an organization within which market transactions are replaced by a nexus of contracts that governs trade among the contracting parties. In this theory, Coase formally recognized the role of the entrepreneur, who organizes the firm and directs the transactions that occur within the organization. Coase's entrepreneur is the central figure in the nexus of contracts that comprises the firm, is party to all contracts, negotiates separately with each of the firm's stakeholders, and has the exclusive right to sell or disband the organization. ${ }^{155}$

In the 1970s, a number of scholars began to extend Coase's insights to the public corporation. ${ }^{156}$ More recently, scholars have argued that the takeover wave of the 1980s provided the crucible that ultimately forged this view into a unified and well-articulated theory. ${ }^{157}$ The most obvious difference between a public corporation and the organization envisioned by Coase is the absence of an entrepreneur. Granted, the managers of public corporations have certain responsibilities that are the same as those of Coase's entrepreneur. Unlike Coase's entrepreneur, though, corporate managers are not the providers of capital, nor are they the firm's residual claimants. In the public corporation, these functions are performed by outside investors. However, in the nexus-ofcontracts paradigm, outside investors are simply one of the stakeholder groups that comprise the contracting parties of the corporate organization. This view recognizes that there are both internal and external markets and that certain transactions can be effected more efficiently in one market than in the other. Thus, Coase's fundamental insight that firms consist of a nexus of contracts designed to reduce the costs of trade is not vitiated by the lack of an entrepreneur in the public corporation. It is simply that in the public corporation, the many functions of Coase's entrepreneur are performed by distinct stakeholder groups. Indeed, this specialization in functions gives a certain efficiency to corporations over sole proprietorships. ${ }^{158}$

154. See Coase, supra note 4 , at 392.

155. See generally id.

156. See, e.g., Alchian \& Demsetz, supra note 6, at 783-85; Jensen \& Meckling, supra note 3.

157. See, e.g., William J. Bratton, Jr., The New Economic Theory of the Firm: Critical Perspectives from History, 41 STAN. L. REV. 1471 (1989); Ronald Daniels, Stakeholders and Takeovers: Can Contractarianism Be Compassionate?, 43 U. TORONTO L.J. 315, 315-17 (1993); Michael C. Jensen \& Richard S. Ruback, The Market for Corporate Control: The Scientific Evidence, 11 J. FIN. ECON. 5 (1983).

158. See Eugene F. Fama \& Michael C. Jensen, Separation of Ownership and Control, 26 J.L. \& ECON. 301, 308 (1983). 
Contractarians reject the proposition that the corporation should be viewed as a distinct and identifiable entity. Rather, they view the corporation as the collection of explicit and implicit contracts that binds the various stakeholder groups together. ${ }^{159}$ Stakeholder groups are free to bargain with one another within the bounds set by existing contracts and agreements. However, in most instances, corporate managers facilitate the bargaining process by negotiating with each of the stakeholder groups separately. For example, labor contracts are negotiated separately from product-market contracts, even though the terms of the latter must necessarily affect the terms of the former.

The central role of contracts and market transactions in the contractarian paradigm extends beyond the internal workings of the corporation. Takeovers are an external, market-based force; they insure the efficiency of the internal contracts, helping to create an environment to insure the efficiency of the contracting process. ${ }^{160}$ That U.S. corporations are creatures of the various fifty states, together with the fact that these states actively compete for firms to incorporate in their jurisdictions, lends an additional competitive or efficiency aspect to the contractarian model. ${ }^{161}$ External capital markets, with adequate corporate disclosure and the ability for investors to freely enter and exit the capital market; competitive product markets, with well-developed and wellenforced antitrust rules that ensure competition; managerial labor markets; and the ability and willingness of the government to recognize, assign, and enforce property rights are important additional elements of the corporation's environment that aid in the efficiency of contracting. Inefficiency in contracting will be penalized by the market, and these penalties provide the impetus for self-correcting behavior. Thus, contractarianism is an internally consistent, self-correcting paradigm for a corporate economy.

b. Implications of the Contractarian View. The implications of the contractarian view of the corporation are far-reaching. It pierces the corporate facade and forces individuals and, more importantly, public officials to talk about people and not a vague, amorphous fiction called the corporation. Thus, by this view, corporations do not pay taxes; instead, stockholders are double taxed. Corporations themselves do not pollute; rather, employees of corporations pollute. Corporations are not liquidated; rather, bondholders are not willing to finance the continuation of the firm's activities.

The contractarian view thus has significant implications for public policy. Appropriate public policy differs dramatically if one considers the corporation a legal entity rather than viewing it as an abstraction of a collection of contracts freely negotiated by corporate stakeholders. If the corporation is a self-

159. Interestingly, the emergence of network organizations can be seen as an illustration, if not an affirmation, of a contractarian organizing logic. See supra notes 76-89 and accompanying text.

160. See Michael C. Jensen, Takeovers: Their Causes and Consequences, J. ECON. PERSP., Winter 1988 , at $21,22-23$.

161. See Peter Dodd \& Richard Leftwich, The Market for Corporate Charters: "Unhealthy Competition” Versus Federal Regulation, 53 J. Bus. 259 (1980). 
interested, legal entity, then it has the potential to inflict harm on society just as a natural person does, and its actions, therefore, must be regulated. Alternatively, if the corporation is nothing more than a collection of contracts, then any government intervention into the affairs of public corporations must be evaluated in terms of its effect on the ability of individuals to contract freely. From this perspective, the role of government typically is relegated simply to protecting property rights and enforcing contractual agreements.

The freedom of self-interested, rational individuals to enter into voluntary contracts is the primary concern of contractarians, and individual liberty is a cornerstone of the contractarian philosophy. The working of Adam Smith's invisible hand, which transforms individual self-interest into an optimal allocation of society's resources, provides the moral and economic justifications for the contractarian view. ${ }^{162}$ By this view, a corporate economy, unfettered by government regulation, in which self-interested individuals can write and enforce mutually beneficial contracts, maximizes not only individual freedom but economic efficiency as well. ${ }^{163}$

An important implication of the contractarian view is that the objective of corporate managers is to maximize the value of the firm's residual claims, which typically are the firm's common stock. Characterizing the production process of firms in a capitalistic economy as "team production," Alchian and Demsetz argue that to minimize shirking and therefore maximize output, control of the team should be vested in the residual claimant. ${ }^{164}$ Consequently, in the contractarian framework, the fiduciary duties of corporate managers run exclusively to the firm's stockholders. It must be stressed that the principle of maximizing shareholder wealth derives not from any philosophical predilection to favor this stakeholder group over others. Rather, the preeminence of the stockholders in the contractarian paradigm follows from their position as residual claimants. Only residual claimants have the incentive to maximize the total value of the corporation. All of the other stakeholder groups are, to some extent, fixed-claim holders and, therefore, do not have any incentive to increase the value of the firm beyond the point that the payment of their fixed claim on

162. See Adam Smith, An InQuiry into the Nature and Causes of the Wealth of NATIONS (Oxford University Press 1923) (1776).

163. See Milton Friedman, The Social Responsibility of Business is to Increase Its Profits, N.Y. TiMES, Sept. 13, 1970 (Magazine), at 32.

164. See Alchian \& Demsetz, supra note 6, at 782.

Specialization in monitoring plus reliance on a residual claimant status will reduce shirking. The specialist who receives the residual awards will be the monitor of the members of the team (i.e., will manage the use of cooperative inputs). The monitor earns his residual through the reduction in shirking that he brings about, not only by the prices that he agrees to pay the owners of the inputs, but also by observing and directing the actions or uses of these inputs. Hence, team members who seek to increase their productivity will assign to the monitor not only the residual claimant right but also the right to alter individual membership and performance on the team.

Id. 
the firm is assured. Control of the public corporation resides with its residual claimants because they value this control right above all other stakeholders. ${ }^{165}$

Because shareholder-wealth-maximization is the focal point in the contractarian view of the public corporation, many of its detractors refer to it as a prostockholder view. Quite ironically, this often leads to a description of an alternative view that is labeled a pro-stakeholder view, one that presumably takes into account the interests of all stakeholders. ${ }^{166}$ The irony is that the contractarian view is manifestly pro-stakeholder. Under perfect market conditions, all wealth-maximizing stakeholders at the time the firm is formed would agree that managers should run the firm so as to maximize the value of the firm's residual claim or common stock. The proposition that maximizing the residual claim of a public corporation in turn maximizes the claims of all stakeholders is a more general application of the so-called "market value rule" of corporate finance. Eugene F. Fama and Merton H. Miller demonstrate that under conditions of perfect markets, the market value rule maximizes the value of all the firm's outstanding securities, provided of course, that the firm's security holders "are free to compensate one another for the effects of operating decisions that increase the wealth of one group but not the other." ${ }^{167}$ It is a short step to generalize this proposition to all stakeholders. Thus, assuming that side payments among stakeholders are possible, pursuing the market value rule ensures that the values of all stakeholders' claims are maximized.

Of course, application of the market value rule requires-as does the entire contractarian paradigm - the ability of stakeholders to conduct Coasean bargains to eliminate all third-party effects. ${ }^{168}$ This assumption is potentially the Achilles' Heel of the contractarian model.

c. A Critique of Contractarianism. Because contractarianism relies on the sanctity of contracts, the most damaging critiques of the position emphasize situations where contracting is costly or impossible. Contractarians presume that contracts can be written to contemplate all possible contingencies. Unfortunately, this is an ideal that never can be reached. There always will be inevitable contractual incompleteness due to ambiguities in language,

165. See Jonathan R. Macey \& Geoffrey P. Miller, Corporate Stakeholders: A Contractual Perspective, 43 U. TORONTO L.J. 401 (1993).

166. See R. EdWARd FreEman, Strategic MANAGEMENT: A StAKEHOlder Approach 22-27 (1984).

167. Eugene F. FAma \& Merton H. Miller, The Theory of Finance 179 (1972).

168. The notion of a Coasean bargain stems from the so-called Coase Theorem, which was first stated, though not under that name, in R. H. Coase, The Problem of Social Cost, 3 J.L. \& ECON., Oct. 1960, at 1. See generally Robert D. Cooter, Coase Theorem, in 1 THE NEW PALgRAVE: A DICTIONARY OF ECONOMICS 457 (John Eatwell et al. eds., 1987) (presenting an overview of the theorem). The theorem states that in a world with zero transaction costs, initial rights allocations are unimportant; they will be transferred to their highest-value use through private, Coasean, bargains. Thus, in the present context, if an action taken by a corporation harms one group of stakeholders more than it helps another, the former group will bribe the latter group to abandon the action in question. Maximizing the residual claim maximizes the size of the corporate pie. The way this pie will be allocated among the firm's various stakeholders will depend on the Coasean bargains they work out with one another. 
inadvertence, unforeseen circumstances, and disputes concerning observability, parties' precontracting intentions, measurability, and verifiability of contract terms and outcomes. ${ }^{169}$

If contracts are inefficient and incomplete, the pure contractarian position is untenable. Critics argue that information asymmetries, transaction costs, and outright fraud are insurmountable obstacles to efficient contracting solutions. ${ }^{170}$ For example, contractarians assume that the agency problem between stockholders and corporate managers can be solved through contracting. ${ }^{171}$ However, a plethora of theoretical and empirical papers demonstrates the inability of contracts to eliminate the agency costs of the corporate form. ${ }^{172}$ Critics also point out that serious imperfections and impediments in the market for corporate control belie the notion that outside forces exert pressure on corporate managers to maximize shareholder wealth. ${ }^{173}$ Indeed, evidence testifying to the efficiency of top-management discipline born of this market is equivocal at best. $^{174}$

Another limitation of the contractarian view is that it does not recognize the many individuals who are affected by, but are not directly party to, the corporate contract. ${ }^{175}$ Put simply, a contract between two parties may harm a third. For example, a contract between a firm and a creditor may create externalities for other creditors directly by altering priority rules, or indirectly by altering managerial incentives. ${ }^{176}$ Thus, so-called externalities or third-party effects vitiate the claim that the freedom of individuals to enter into voluntary, mutually beneficial contracts will result in the optimal allocation of society's resources.

Technically, third parties have the freedom to join the corporate contract. However, transaction costs, incomplete or asymmetric information, duress, assessment of contingencies, collusion, and incomplete verifiability of actions and outcomes render this impractical. It is impossible for individuals to comprehend, let alone write, contracts that anticipate the innumerable ways in which they could be affected by the actions taken by the affiliates of some unknown corporation. For example, how could the victims of the Bhopal disaster have anticipated the actions taken by the employees of Union Carbide and ex ante

169. See Alan Schwartz, Legal Contract Theories and Incomplete Contracts, in CONTRACT ECONOMICs 76, 76-80 (Lars Werin \& Hans Wijkander eds., 1992).

170. See id.

171. See Amir Barnea et Al., Agency Problems and Financial Contracting (1985) (and references therein).

172. See id.

173. See e.g., Jensen, supra note 13, at 850-62; Shleifer \& Vishny, supra note 10, at 7-11.

174. See James P. Walsh \& John W. Ellwood, Mergers, Acquisitions, and the Pruning of Managerial Deadwood, 12 StRAtegic MGMT. J. 201, 214-16 (1991); James P. Walsh \& Rita D. Kosnik, Corporate Raiders and Their Disciplinary Role in the Market for Corporate Control, 36 ACAD. MGMT. J. 671, 691 (1993).

175. See John et al., supra note 143 , at 56.

176. See Jean Tirole, Comments on Legal Contract Theories and Incomplete Contracts, in CONTRACT ECONOMICS, supra note 169, at 109. 
contracted with the company to obtain insurance or taken sufficient precautions to prevent such an accident from occurring? ${ }^{177}$

The contractarian view of the corporation is perhaps most vulnerable to attack when dealing with cross-border transactions. The contractarian view requires the existence of property rights and a judicial process that is willing and able to enforce contract terms. These conditions do not exist in many of the emerging economies throughout the world. Consider, for instance, the difficulties in the enforcement of intellectual property rights in the People's Republic of China. ${ }^{178}$ Even in economic exchanges among the so-called developed economies, there are innumerable problems that arise because of conflicting or inconsistent legal systems such as civil law versus common law versus religious law, regulations, customs, traditions, languages, and mores. ${ }^{179}$ Areas of direct concern to corporations and corporate governance in which there are voids at the intersections of sovereign boundaries include antitrust enforcement, liability rules, bankruptcy and creditor protection laws, disclosure rules, and employment laws. Indeed, the absence of a superstructure to enforce contracts across borders is a problem for the contractarian view because, in the final analysis, all international law, and hence all international contracting, is a matter of voluntary acceptance of jurisdiction, mediation, and judgments on the part of the contracting parties.

Finally, there are those who argue that even if the contractarian view results in maximum economic efficiency, it does not achieve maximum social welfare. $^{180}$ Allowing individuals to engage in free trade will not rectify the inequalities stemming from the inequitable distribution of wealth or bargaining power of certain individuals and coalitions. This view-consistent with the views of communitarians-holds that the corporation is a social organization

177. See John et al., supra note 143, at 65-66. The abstract economic language about negative externalities belies the deep emotion that gives form to the critique captured by this economic construct. The Bhopal accident is one example of such problems. For an example of how heartfelt the criticism of the firm can be, see Jeff Gates's discussion of the anger, grief, and mourning that he believes will accompany society's acceptance of these externalities:

The anger will emerge from the shared consciousness of what we've allowed our

"unconscious capitalism" to do-to ourselves, to our fellow man, to our children and to nature. The genetic defects, the needless cancers, the stunted growth of chemically abused children, the denuded landscapes, the endangered aquifers, the depleted oceans, the lost species.... The list is an endless recitation of senseless tragedy bred of blind human selfabsorption whose cause lies deep within the very paradigm on which we base our standard of living.

JEFF GATES, THE OWNERSHIP SOLUTION: TOWARD A SHARED CAPITALISM FOR THE TWENTY-FIRST CENTURY 296 (1998).

178. See Glenn R. Butterton, Pirates, Dragons and U.S. Intellectual Property Rights in China: Problems and Prospects of Chinese Enforcement, 38 ARIZ. L. REV. 1081, 1082-84 (1996); Julia Cheng, Note, China's Copyright System: Rising to the Spirit of TRIPs Requires an Internal Focus and WTO Membership, 21 FORDHAM INT'L L.J. 1941, 1969 (1998).

179. See generally Sundaram \& Black, supra note 144, at 735-38 (discussing the problems of state sovereignty for MNEs).

180. For a broad critique of libertarian economic theory and practice, see ROBERT KUTTNER, EVERYTHING FOR SALE: THE VIRTUES AND LIMITS OF MARKETS (1997). 
and, as such, has social responsibilities that transcend achieving economic efficiency.

\section{Communitarianism.}

a. Communitarianism Defined. The contractarian ideology has clearly dominated the discourse in the worlds of law, economics, and management during the past fifteen or twenty years. Indeed, after observing this phenomenon, Chancellor Allen of the Delaware Chancery Court observed that "[o]ne of the marks of a truly dominant intellectual paradigm is the difficulty people have in even imagining any alternative view." 181 That said, an alternative view does exist. Recognized by the press, ${ }^{182}$ often associated with the work of Amitai Etzioni, ${ }^{183}$ and increasingly represented in both the law and economics literature ${ }^{184}$ and the management literature, ${ }^{185}$ the communitarian paradigm has emerged as the alternative to contractarian thinking. Its origins lie in the worlds of both theory and practice.

Communitarianism finds its origins in a long-standing controversy about human nature. For centuries, sociologists and philosophers have debated the primacy of individuals or collectivities in the understanding of social life. ${ }^{186}$ Some believe that self-interested individual decisionmaking lies at the center of social, political, and economic life. ${ }^{187}$ Others believe that personal preferences and decisions are shaped by, and largely explained by, the social structure and context within which people live. ${ }^{188}$ Contractarianism is rooted in assumptions

181. William T. Allen, Contracts and Communities in Corporation Law, 50 WASH. \& LEE L. REV. 1395, 1401 (1993); see also William T. Allen, Our Schizophrenic Conception of the Business Corporation, 14 CARDOZO L. REV. 261, 261-64, 72 (1992).

182. See Freedom and Community: The Politics of Restoration, ECONOMIST, Dec. 24, 1994, at 33.

183. See Amitai Etzioni, The SPIRIT of COMMUnity: THE REINVEnTION OF AMERICAN SOCIETY (1993); AMITAi ETZIOni, THE MORAl Dimension: TOWARD A NEW ECONOMICS (1988).

184. See, e.g., Progressive Corporate LAW (Lawrence E. Mitchell ed., 1995); Thomas Lee Hazen, The Corporate Persona, Contract (and Market) Failure, and Moral Values, 69 N.C. L. REV. 273 (1991); David Millon, New Directions in Corporate Law: Communitarians, Contractarians, and the Crisis in Corporate Law, 50 WASH. \& LEE L. REV. 1373 (1993). But see Stephen M. Bainbridge, Community and Statism: A Conservative Contractarian Critique of Progressive Corporate Law Scholarship, 82 CORnell L. Rev. 856, 857-58 (1997) (reviewing PROGRessive CORPORATE LAW (Lawrence E. Mitchell ed., 1995)).

185. See Max B. E. Clarkson, A Stakeholder Framework for Analyzing and Evaluating Corporate Social Performance, 20 ACAD. MGMT. REV. 92 (1995); FREEMAN, supra note 166.

186. See infra note 188 and accompanying text.

187. See JAmes S. COLEMAN, Foundations of Social THEORY (1990); infra note 188 and accompanying text.

188. The differing perspectives are illustrated by the well-known tensions between the ideas of Thomas Hobbes and Jean Jacques Rousseau, as well as by the distinction between organic and mechanistic solidarity, gemeinschaft and gesellschaft, under-socialized and over-socialized conceptions of individual behavior, and even the distinction between Whigs and Tories. See generally EMILE DURKHEIM, THE DIVISION OF LABOR IN SOCIETY (MacMillan 1984) (1893) (discussing the consequences of the division of labor on societal cohesion and solidarity); THOMAS HOBBES, LEVIATHAN (Guernsey Press 1973) (1651); JEAN JACQUES RousSEAU, THE SOCIAL CONTRACT (Charles Frankel ed., Hafner Publishing 1955) (1762); F. TÖNNIES, COMMUNITY AND SOCIETY (GEMEINSCHAFT UND GESELlSCHAFT) (Charles P. Loomis trans. \& ed., Michigan State University Press 1957); Mark Granovetter, Economic Action and Social Structure: The Problem of Embeddedness, 91 AM. J. SoC. 481 
of utilitarian and methodological individualism, while communitarianism finds its roots in humanism and methodological holism. ${ }^{189}$ The current primacy of contractarian thinking should not be misread as evidence that no other theoretical world view exists.

Turning to business practice, those who view the firm not as an economic aggregation of individuals but rather as an entity, connected in some organic fashion with our social, historical, and political world, ask how economic activity serves society. Indeed, by providing limited liability and various constitutional protections to the corporation, society accords the corporation entity status in the eyes of the law. In this light, Thomas Lee Hazen raises a key question: "What is the quid pro quo that society exacts for granting this special privilege to corporations?" 190 In a famous paper, E. Merrick Dodd answered this question years ago: "[A] sense of social responsibility toward employees, consumers, and the general public may thus come to be regarded as the appropriate attitude to be adopted by those who are engaged in business."191 However, communitarians look for evidence in support of Dodd's assertion and come away disappointed. Discussions of externalities and contract failure may explain-but not explain away-the fact that corporations often harm or exploit many in society who have a stake in their activities. ${ }^{192}$ A point of departure for communitarian thinking then is a desire to redress and prevent the harms that firms may inflict upon society. ${ }^{193}$

The conceptual battle lines are stark. Where contractarianism finds its legitimacy in the values of liberty and competition, communitarians emphasize justice and cooperation. Where contractarians look to Adam Smith's invisible hand for a social welfare logic to justify the distribution of gains from corporate activity, communitarians yearn for an authentic community where the fulfillment of the true needs of society's members justifies corporate activity. ${ }^{194}$ Focusing on the managerial means to achieve corporate ends, contractarians invoke norms of freedom, while communitarians emphasize responsibility.

(1985) (discussing conceptions of individual behavior); Dennis H. Wrong, The Oversocialized Conception of Man in Modern Sociology, 26 AM. SOC. REV. 183 (1961) (discussing conceptions of individual behavior); ETZIONI, THE MORAL DIMENSION, supra note 183, at 6-8 (discussing under-socialized and over-socialized and Whigs and Tories).

189. See Antonin Wagner, Communitarianism: A New Paradigm of Socioeconomic Analysis, $24 \mathrm{~J}$. SOCIO-ECON. 593, 598 (1995).

190. Hazen, supra note 184, at 296.

191. E. Merrick Dodd, Jr., For Whom are Corporate Managers Trustees?, 45 HARV. L. REV. 1145, 1160 (1932).

192. See supra notes $169-180$ and accompanying text.

193. Morrissey's work places the tension between contractarian and communitarian thinking in an historical perspective. See Daniel J. Morrissey, Toward a New/Old Theory of Corporate Social Responsibility, 40 SYRACUSE L. REV. 1005 (1989). While not denying the logic of Allen's observation, supra note 181 and accompanying text, Morrissey traces the reemergence of contractarian thinking using Friedman's New York Times essay, supra note 163, referring to it as a "[c]ounterattack from the [t]raditionalists." Id. at 1023-25.

194. See Amitai Etzioni, The Responsive Community: A Communitarian Perspective, 61 AM. SoC. REV. 1, 3 (1996) (discussing authentic communities). 
Finally, both camps conjure up an image of a sinister world if their paradigm is not embraced. The contractarians warn of slavery and oppression if communitarians have their way, while communitarians fear exploitation and alienation if contractarianism is unchecked. Table 3 captures the fundamental distinctions between these two corporate worldviews. 
TABLE 3

CONTRACTARIANISM VERSUS COMMUNITARIANISM

\begin{tabular}{|c|c|c|}
\hline & Contractarianism & Communitarianism \\
\hline Human Nature & Utilitarian individualism & Humanistic holism \\
\hline The Firm & $\begin{array}{l}\text { An economic organization } \\
\text { defined as an aggregation of } \\
\text { individuals }\end{array}$ & $\begin{array}{l}\text { A social, political, historical, } \\
\text { and economic entity }\end{array}$ \\
\hline Legitimation & Competition, liberty & Cooperation, justice \\
\hline Social Welfare & Invisible hand & Need fulfillment \\
\hline Decision Norms & Freedom & Responsibility \\
\hline Feared Alternative & Slavery, oppression & Exploitation, alienation \\
\hline Manager's Role/Duty & $\begin{array}{l}\text { Maximize shareholder wealth } \\
\text { within the bounds of the law }\end{array}$ & $\begin{array}{l}\text { A multifiduciary duty to all } \\
\text { stakeholders }\end{array}$ \\
\hline Internal Control & $\begin{array}{l}\text { Pricing of contractual } \\
\text { exchanges }\end{array}$ & $\begin{array}{l}\text { Trust among those in } \\
\text { embedded relationships }\end{array}$ \\
\hline Role of Law & $\begin{array}{l}\text { Promotion of ex ante } \\
\text { contractual freedom }\end{array}$ & $\begin{array}{l}\text { Promotion of ex post } \\
\text { distributive fairness }\end{array}$ \\
\hline
\end{tabular}

b. Implications of the Communitarian View. Three areas in which contractarian thinking is manifest in organizational life have been identified: (1) the manager's role in maximizing shareholder wealth within the bounds of the law; (2) maintenance of internal control by the pricing of contractual exchanges; and (3) the role of law as promoter of ex ante contractual freedom. Communitarians, on the other hand, believe that corporate managers have a social responsibility not only to the shareholders, but to all of the firm's stakeholders. Consistent with Dodd's early sentiments, ${ }^{195}$ Clarkson's recent exhortations are emblematic of thinking in this area: "Managers are now accountable for fulfilling the firm's responsibility to its primary stakeholder groups." 196 While contractarians rely on bargaining between the firm and its stakeholders to meet the needs of these stakeholders, communitarians worry about the equity implications of such arrangements in light of information and power asymmetries, as well as the problem of negative externalities that arise when some stakeholders do not have the opportunity to bargain with the firm at all. Communitarians want firms to be responsive to all stakeholders. Of

195. See Dodd, supra note 191.

196. Clarkson, supra note 185 , at 112. 
course, this sentiment raises the question of how a firm's value should be allocated among the various stakeholders. Communitarians would respond with the notion of a "true" need. A "true" need is evidenced by the persistence of a behavior absent social control. ${ }^{197}$

Communitarians envision a far different world of internal control than the one marked by contract setting and enforcement. ${ }^{198}$ Added to the list of the problems with contracting specified earlier is the recognition that, at their best, contracts yield compliant behavior and not commitment. ${ }^{199}$ Moreover, as Ouchi has shown, the behavioral and outcome specifications needed to establish contracts are illusory in a world where tasks cannot be programmed nor their outcomes validly measured (that is, post-industrial work). ${ }^{200}$ Clan or trust-based control, the kinds of control that are consistent with the communitarian concept of human nature and the firm, is necessary in these circumstances. ${ }^{201}$

Turning to their views of law, contractarians view law as a means of ensuring ex ante freedom and efficiency of contracting, ${ }^{202}$ while communitarians see law as a vehicle to ensure distributive justice and equity from the payoffs to contracts. In practice, the communitarian view argues for various types of corporate constituency statutes: the ability to choose different rules for different situations. $^{203}$ As discussed above, a variety of these types of statutes have been adopted during the past few decades. ${ }^{204}$

c. A Critique of Communitarianism. To be sure, there are laudatory aspects of a communitarian system. Who would object to corporations being more socially responsible? Clearly, society would be better off if discrimination, pollution, workplace hazards, and dangerous products could be eliminated without serious effects on incentives or resource allocation. Moreover, if individuals believe they have lifetime employment, they may be

197. See Etzioni, supra note 194, at 6.

198. See, e.g., Virginia Held, Mothering Versus Contract, in BEYOND SELF-INTEREST 287 (Jane J. Mansbridge ed., 1990).

199. For sociological discussion of compliance, see Herbert C. Kelman, Processes of Opinion Change, 25 PUB. OPINION Q. 57 (1961).

200. See Ouchi, supra note 28; Ouchi, supra note 137.

201. Powell provides a succinct definition of how communitarians view trust, and thus control, in organizational life. He suggests that it is "a by-product of the embeddedness of individuals in a web of social relations such that values and expectations are commonly shared." W.W. Powell, Trust-Based Forms of Governance, in TRUST IN ORGANIZATIONS: FRONTIERS OF THEORY AND RESEARCH 51, 62 (Roderick M. Kramer \& Tom R. Tyler eds., 1996). A recent special research forum on intra- and inter-organizational cooperation, see Ken G. Smith et al., Intra- and Interorganizational Cooperation: Toward a Research Agenda, 38 ACAD. MGMT. J. 7 (1995), the recent collection of essays on trust in organizations, see TRUST IN ORGANIZATIONS, supra, and a special topic forum on TRUST IN AND Between Organizations, see Denise M. Rousseau et al., Not So Different After All: A CrossDiscipline View of Trust, in 23 ACAD. MGMT. REV. 393 (1998) (Introduction to Special Topic Forum), signal a resurgent interest among management scholars to better understand such forms of control and their links to communitarian ideas.

202. See EASTERBROOK \& FISCHEL, supra note 149, at 15-16.

203. See Eric W. Orts, The Complexity and Legitimacy of Corporate Law, 50 WASH. \& LEE L. REV. 1565,1581 (1993).

204. See, e.g., supra note 134 and accompanying text. 
more willing to invest in firm-specific human capital. This would make corporations more efficient. Arguably, employees in labor-managed firms work harder because they share directly in the firm's prospects. However, the tensions enumerated in Table 3 expose the shortcomings of the communitarian view of governance. Each aspect of the communitarian paradigm can be countered by an opposing contractarian argument. As noted above, issues regarding the fundamental nature of individuals and the corporation have been debated in various forms for centuries. ${ }^{20 .}$

The argument for responsible, true-need fulfillment on the part of the multifudiciary firm can be countered in any number of ways. Who decides whether a need is true or false? What is the social, economic, and political legitimacy of the entity that makes that decision? Some needs are insatiable (for example, wealth), while others are satiable (for example, thirst and hunger)—is one type of need more or less true than the other? Is there a reasonable limit to the firm's responsibilities? Who defines these limits? What are the penalties and the self-correction mechanisms for violators?

In a world where companies routinely cross national boundaries and where the companies' boundaries themselves are blurred by network relationships, it is impossible to fulfill the needs of every possible stakeholder that might be touched by the global reach of the firm. Who will place capital at risk in a company that unilaterally seeks to fulfill such stakeholders' true needs? An investment in such a firm might be better cast as a charitable contribution. Finally, resource dependence theory suggests that a great deal of power will accrue to the firms who satisfy so many human needs. ${ }^{206}$ At best, the leaders of such companies may exercise their power in a benevolent and paternalistic way. At worst, Lord Acton's words, "power tends to corrupt and absolute power corrupts absolutely," may foreshadow an even gloomier future. ${ }^{207}$

Other discrete aspects of the communitarian paradigm can be critiqued. Frank H. Easterbrook and Daniel R. Fischel argue that it is impossible for a fiduciary to serve beneficiaries whose interests conflict. ${ }^{208}$ As such, mangers cannot be asked to act as fiduciaries for stakeholders in conflict. ${ }^{209}$ Moreover, the

205. "The naiveté of the Left has long been reflected in their attempts to construct a system to change human nature to achieve social justice instead of nurturing an economic environment that evokes social justice while accommodating human nature." GATES, supra note 177, at 291 (footnote omitted).

206. See JefFrey PfefFer \& Gerald R. SAlancik, The External Control of OrGANIZATIONS: A RESOURCE DEPENDENCE PERSPECTIVE 50-54 (1978).

207. The OXFord Dictionary OF QuOTATIONS 1 (Angela Partington ed., 4th ed. 1996). In addition, it is a little-known fact that Adolf Hitler was one of the first politicians to embrace communitarian thinking. The passage of the German corporation law in 1937 enabled him to focus the German economy on serving of the broader needs of the German people, as he defined them, rather than on earning economic rents. This act presaged his fascist regime. For a more comprehensive discussion of these issues, see Detlev F. Vagts, Reforming the "Modern" Corporation: Perspectives from the German, 80 HARV. L. REV. 23, 26-31 (1966).

208. See EASTERBROOK \& FisCHEL, ECONOMIC STRUCTURE, supra note 149, at 112-13.

209. Giving form to this debate, McDaniel later criticized this argument. See Morey W. McDaniel, Stockholders and Stakeholders, 121 STETSON L. REV. 122 (1991). 
nature of trust itself is in question. Communitarians may view trust as a byproduct of embedded social life, but others see trust emerging from repeated exchanges, exchanges that can be grounded in contractual relationships. ${ }^{210}$ As a result, trust can be seen as a derivative of - and not a substitute for-contracts.

The final critique of communitarianism is that it is neither self-referential nor does it offer a positive logic to organize economic production. ${ }^{211}$ The limits to contractarian thought are apparent in the limits to contracting, that is, incomplete information, hold-ups, bounded rationality, externalities, and so forth. A self-referential critique of communitarianism is not so readily apparent. As noted above, the criticisms are much more subtle. For instance, a system rooted in a multifiduciary commitment to justice ironically can become a tool of tyrannical injustice in the wrong hands. ${ }^{212}$ In other words, the limits of communitarianism may not be recognized until it is too late.

\section{B. Toward a Practical Resolution: American Law Institute Section 2.01 and Beyond}

Against this backdrop, the American Law Institute ("ALI") began its Corporate Governance Project in $1979 .{ }^{213}$ The part of the project most closely related to the issues addressed in this article is Section 2.01. Section 2.01 defines the objective and conduct of the corporation as follows:

(a) Subject to the provisions of Subsection (b) and $\S 6.02$ (Action of Directors That Has the Foreseeable Effect of Blocking Unsolicited Tender Offers), a corporation [ $\$$ 1.12] should have as its objective the conduct of business activities with a view to enhancing corporate profit and shareholder gain.

210. See Powell, supra note 201, at 63.

211. "Self-referential" is the ability of a system of ideas to embed its own critique.

212. See supra notes $205-210$ and accompanying text.

213. The ALI is a non-profit institute that seeks to simplify and clarify the law in the United States. It includes representatives of legal practitioners, the judiciary, and academics. The ALI considered a corporate law project back in the 1920s and 1930s but was reluctant to pursue it until 1979 when it began its Corporate Governance Project. See Richard B. Smith, An Underview of the Principles of Corporate Governance, 48 BUS. LAW. 1297, 1298 (1993). Many previous projects undertaken by the ALI have resulted in restatements of law. Although such restatements do not have the force of law, they are often cited by the courts and commentators as accurate summaries and portrayals of the law. Since its adoption in 1992, the ALI's PRINCIPLES OF CORPORATE GOVERNANCE has been cited 141 times in published state and federal cases. See 1998 AnN. REP. 24. The ALI began its Corporate Governance Project as a restatement, but the name of the project was eventually changed to its final title, Principles of Corporate Governance: Analysis and Recommendations. There was some conflict over the prior use of "Restatement" in the original title. It was replaced with "Analysis," which was appropriate given the heavy element of analysis. See AMERICAL LAW INSTITUTE, PRINCIPLES OF CORPORATE GOVERNANCE: ANALYSIS AND RECOMMENDATIONS xx (1994). The project, however, was written in the same manner as any other restatement.

The intent of the project was not to draft a model state corporation law or new federal corporation law. Instead, the focus was "on issues of governance responsibilities and to state existing or recommended ground rules ... to be implemented by the courts, ... legislatures, and ... by corporations themselves." Id. at xx-xxi. The Uniform Commercial Code (UCC), Model Penal Code (MPC), Study of Division of Jurisdiction between State and Federal Courts, and Federal Securities Code were among the examples mentioned that addressed legal problems requiring legislative treatment. "A basic purpose of the Project has always been to clarify the duties and obligations of corporate directors and officers and to provide guidelines for discharging those responsibilities in an efficient manner, with minimum risks of personal liability." Id. at xxi. 
(b) Even if corporate profit and shareholder gain are not thereby enhanced, the corporation, in the conduct of its business:

(1) Is obliged, to the same extent as a natural person, to act within the boundaries set by law;

(2) May take into account ethical considerations that are reasonably regarded as appropriate to the responsible conduct of business; and

(3) May devote a reasonable amount of resources to public welfare, humanitarian, educational, and philanthropic purposes. ${ }^{214}$

Although Section 2.01 was thought to be consistent with the case law, it has sparked controversy. ${ }^{215}$ Subsection (a) provides for shareholder primacy, which, as a general rule, is consistent with the case law and the contractarian model. $^{216}$ Subsection (b), however, allows reasonable ethical and charitable considerations to supersede shareholder primacy, a sentiment more in line with a communitarian viewpoint. ${ }^{217}$

Addressing the construction of section 2.01(b), Professor Eisenberg, the Chief Reporter and reporter for this part, noted that in addition to the goal of enhancing corporate and shareholder gains, "[a] second premise of corporation law is that in pursuing the profit objective, the corporation should conduct itself with regard to the fact that it is a social as well as an economic institution."218 The social elements are implicated in three realms. First, subsection (b)(1) makes it clear that corporations must operate within the constraints of law, which, on its face, is a reasonable proposition. ${ }^{219}$ Subsection (b)(2), allowing

214. AMERICAN LAW INSTITUTE, supra note 213, at 55.

215. See Donald E. Schwartz, Defining the Corporate Objective: Section 2.01 of the ALI's Principles, 52 GEO. WASH. L. REV. 511, 519-20 (1984).

216. The definitive case supporting shareholder primacy is Dodge Bros. v. Ford Motor Co., 170 N.W. 668 (Mich. 1919); see also Elliott J. Weiss, Economic Analysis, Corporate Law, and the ALI Corporate Governance Project, 70 CORNELL L. REV. 1, 34 (1984).

217. The use of "may" in subsection (b) indicates that compliance with social concerns is not mandatory, but consideration of them should not be precluded by the economic aims of corporation. Section 2.01(b) does not seek to penalize those corporations that do not follow concerns that they consider unreasonable for their purposes, but enables corporations "to go beyond the law's minimum requirements if the cost is reasonable." Schwartz, supra note 215, at 515. It should also be noted that sections 2.01(b)(2) and (3) do not permit a corporation to commit more than a reasonable amount of resources to ethical and charitable considerations. See Larry E. Ribstein, The Mandatory Nature of the ALI Code, 61 GEO. WASH. L. REV. 984, 1008 (1993). It has been further argued, however, that Section 2.01 can be used to show how adopting a tin parachute as a takeover defense would comport with fundamental objectives of enhancing shareholder gain. See Patrick J. Ryan, Corporate Directors and the "Social Costs" of Takeovers-Reflections on the Tin Parachute, 64 TUL. L. REV. 3, 35-36 (1989).

218. Melvin Aron Eisenberg, An Overview of the Principles of Corporate Governance, 48 Bus. LAW. 1271, 1276 (1993); see also Robert A. Prentice \& John H. Langmore, Shareholder Alternatives to Hostile Takeovers: Restructurings, Auctions and MacMillan II, 20 SETON HALL L. REV. 4, 68-69 (1989) (noting that several cases as well as state codes and the ALI Corporate Governance Project approve the authority of corporate boards to spend funds on charitable contributions); Schwartz, supra note 215, at 514 ("The permissive exceptions to wealth-enhancing activity articulate contemporary business practice.").

219. But see CHARles HANSEN, A GUIDE TO AMERICAN LAW INSTITUTE CORPORATE GOVERNANCE PROJECT 186 (1995) (noting that in conjunction with other sections of the Principles, there are inconsistencies with prior views of the obligation of corporate directors and officers to abide by the law); cf. Cynthia Williams, Corporate Compliance with the Law in the Era of Efficiency, 76 N.C. 
corporate conduct to be guided by reasonable ethical concerns, is based on the observation that corporate policy, like individual behavior, should reflect ethical considerations, and to state otherwise would be "unwise social policy."220 Subsection (b)(3), permitting corporations to devote reasonable resources to charitable concerns, also reflects a social policy orientation, perhaps rooted in the fact that corporations control much of the nation's resources. ${ }^{221}$

Section 2.01 is not without its critics. On the contractarian front, many commentators prefer a stronger shareholder primacy model. For example, Nicholas Wolfson argues for a reliance on market forces, noting that there is no empirical support for the ideas and premises revealed in the ALI Project. ${ }^{222}$ Oliver E. Williamson argues that shareholder gain should be the sole criterion for firm effectiveness because the inclusion of other constituencies' objectives compromises efficiency and invites tradeoffs. ${ }^{223}$ James W. Walker, Jr. notes that the ALI Project would be unacceptable in the business community, objecting to the underlying belief that governance solutions should be based on increased government regulation. ${ }^{224}$ James D. Cox similarly argues that the ALI should anchor the directors' obligation more directly to the shareholders rather than diffuse it over other constituents. ${ }^{225}$

Potential problems also have been noted with the provision granting corporate directors and officers free reign to make decisions based on ethical and charitable considerations. Critics claim there is insufficient shareholder oversight for these decisions ${ }^{226}$ and that shareholders lack the mechanism to express their own preferences. ${ }^{227}$ The Reporter's Note for Section 2.01 similarly indicates that this lack of control can lead to abuse and may prevent shareholders from contractually limiting corporate behavior in this area. ${ }^{228}$ Perhaps even more troublesome are concerns that Section 2.01 may, in fact, encourage management to fulfill their own personal value choices. ${ }^{229}$

L. REV. 1265, 1280-85 (1998) (discussing how parts of the ALI Principles of Corporate Governance favor the view that the law acts as a limit).

220. Eisenberg, supra note 218, at 1276.

221. See id.

222. See Nicholas Wolfson, A Critique of the American Law Institute Draft Proposals, 9 DEL. J.

CORP. L. 629, 631 (1984).

223. See Oliver E. Williamson, Corporate Governance, 93 YALE L.J. 1197, 1219 (1984).

224. See James W. Walker, Jr.,Comments on the ALI Corporate Governance Project, 9 DEL. J. CORP. L. 580, 580 (1984).

225. See James D. Cox, The ALI, Institutionalization, and Disclosure: The Quest for the Outside Director's Spine, 61 GEO. WASH. L. REV. 1233, 1243 (1993).

226. See Faith Stevelman Kahn, Pandora's Box: Managerial Discretion and the Problem of Corporate Philanthropy, 44 UCLA L. REV. 579, 604-05 (1997).

227. See Ribstein, supra note 217, at 1009; see also Jonathan R. Macey, The Transformation of the American Law Institute, 61 GEO. WASH. L. REV. 1212, 1212-13 (1993) (criticizing the ALI Project for "exalt[ing] the role of lawyers and litigation in corporate governance" and for overstating the "extent to which process-oriented reforms are likely to succeed in improving the governance of the American public corporation").

228. See William Carney, The ALI's Corporate Governance Project: The Death of Property Rights?, 61 GeO. WASH. L. REV. 898, 920-21 (1993).

229. See M.J. Pritchett III, Comment, Corporate Ethics and Corporate Governance: A Critique of the ALI Statement on Corporate Governance Section 2.01(b), 71 CAL. L. Rev. 994, 1001, 1007 (1983). 
Interestingly, the ALI project also can be criticized for not going far enough in permitting managers to consider non-shareholder interests. ${ }^{230}$ The permission granted to management to take into account ethical concerns is restricted to only those interests that are "reasonably regarded as appropriate to the responsible conduct of business." "231 There is no mandate for managers to take these considerations into account.

Moreover, even placing these criticisms aside, the project does not specifically address issues of concern to multinational enterprises. Contemporary governance rules need to address issues of cross-border governance structures and recognize differences in the operations of domestic versus multinational firms. For example, even if it is conceded that the project strikes an appropriate balance between the needs of shareholders and societal concerns by permitting management to supersede shareholder gain in the interest of responsible business, how might this standard be evaluated when a U.S. multinational enterprise is faced with a decision involving ethical standards of another country that may differ from those in the United States? Similarly, by providing that a corporation is obliged, to the same extent as a natural person, to comply with legal regulations, the question that immediately arises in the MNE context is, which law? Furthermore, issues of enterprise liability have not been addressed. What is the responsibility of a U.S. parent corporation for a subsidiary operating abroad? What rules govern the conduct of the management of the subsidiary ${ }^{232}$

It is no surprise that the ALI project would come under attack by those espousing either a pure contractarian or communitarian view. But more importantly, it is necessary to look beyond the ALI project to consider the needs of corporate governance in a global environment. To this end, the next section examines the major alternative governance structures observed around the world.

\section{Corporate Governance in a Comparative Setting}

The contractarianism versus communitarianism debate has been going on within the governance literature for nearly 100 years-even longer in its philosophical manifestations. It is unlikely to be settled any time soon. The problem today is that the changes identified above require a reexamination of contemporary corporate governance practices. The ALI project offers some practical guidance, but its contributions are limited. An alternative approach is

230. See generally Laurence E. Mitchell, Private Law, Public Interest?: The ALI Principles of Corporate Governance, 61 GEO. WASH. L. REV. 871 (1993) (arguing that section 2.01 provides no resolution of the question of the appropriate constituents of the corporation); Lewis D. Solomon \& Kathleen J. Collins, Humanistic Economics: A New Model for the Corporate Social Responsibility Debate, $12 \mathrm{~J}$. CORP. L. 331, 332 (1987) (arguing that society can demand a corporate quid pro quo for the privilege of corporate status).

231. AMERICAN LAW INSTITUTE, supra note 213, § 2.01(b)(2), at 55.

232. For an elaboration of many of these issues, see Sundaram \& Black, supra note 144. 
to consider governance practices abroad. ${ }^{233}$ Consequently, this article next will consider an analysis of two leading economies where the governance systems seem to be quite different from that in the United States. The main features of the governance systems in Germany and Japan will be examined with a view toward learning if there are practices that might be imported into the AngloAmerican system. In particular, the following governance attributes of Germany and Japan will be examined: (1) the roles of the board of directors; (2) the role of the managerial labor market; (3) the roles of managerial control and compensation systems; (4) the structure of equity ownership; (5) the nature of monitoring and control exercised by providers of capital; (6) the role of the non-shareholding stakeholders, notably suppliers and employees; (7) the role of the government and regulatory authorities in matters such as antitrust, disclosure, insider trading, tax policies, and corporate law; and, finally, (8) the role of the market for corporate control and takeover defenses.

The focus on the corporate governance systems of Germany and Japan, to the seeming exclusion of other leading economies, is deliberate. Together, the United States, Japan, and Germany comprise the three largest industrial economies in the world, and their gross national products collectively account for slightly more than one-half of the gross world product. ${ }^{234}$ The universe of the largest corporations of the world is substantially populated by firms belonging to one of these three economies. For example, as of the end of 1994, 350 out of the largest 500 non-financial companies in the world were from the United States, Germany, or Japan. ${ }^{235}$ Firms from these economies are most often among the leading global competitors of each other in a wide range of sectors such as automobiles, chemicals, semiconductors, machinery, electrical and electronics, and banking and financial services. To the extent that the nature of corporate governance is closely linked to the nature of industrial organization and market structure, their styles of governance matter in the global competitive arena. Moreover, the governance systems of Germany, Japan, and the United States have had substantial spillover effects beyond their respective borders. Many countries in Europe, such as Austria, Belgium, Hungary, and, to a lesser extent, France and Switzerland, and much of northern Europe evolved their governance systems along Germanic, rather than Anglo-American, lines. The newly liberalizing economies of Eastern Europe appear to be patterning their governance systems along Germanic lines as well. The spillover effects of the Japanese governance system are increasingly evident in Asia where Japanese firms have been the largest direct foreign investors during the past decade. Variants of the Anglo-American system of governance are evident in countries such as the United Kingdom, Canada, Australia, and New Zealand.

233. See Mark J. Roe, Some Differences in Corporate Structure in Germany, Japan, and the United States, 102 YALE L.J. 1927 (1993).

234. See U.S. Bureau of the Census, Statistical Abstract of the United States, 835 tbl.1334, 983 tbl.1335 (1996).

235. See id. at 844 tbl.354. 
1. The German Corporate Governance System. Germany has nearly half a million corporations and more than 3,200 joint-stock companies, known as Aktiengessellschaften ("AGs"), but fewer than 700 are listed in equity markets, with most of the listed firms being incorporated as AGs. ${ }^{236}$ This compares to the more than 9,000 firms listed in the three major stock exchanges in the United States (New York Stock Exchange, American Stock Exchange, and NASDAQ). ${ }^{237}$ Listed firms account for only about twenty percent of the revenues of the corporate sector in Germany, ${ }^{238}$ and stock market capitalization as a percentage of GDP at the end of 1997 is low, at less than forty percent, compared to fifty-seven percent in Japan and $136 \%$ in the United States. ${ }^{239}$ These non-listed firms tend to be mostly the small- and medium-sized enterprises, typically incorporated as GmbHs (Gessellschaften mit beschränkter Haftung). Note, however, that nearly eighty percent of the larger firms, the AGs, are also non-listed. ${ }^{240}$

The goals of German corporations are clearly defined in German corporation law. Originally implemented in 1937, and subsequently modified in 1965, German corporate law defines the role of the board and the objective of corporations as the following (actual German words in parentheses): The managing board is, on its own responsibility, to manage the corporation for the good of the enterprise and its retinue (Gefolgschaft), the common weal of the folk (Volk) and realm demand (Reich). ${ }^{241}$

Nothing specific was mentioned in German corporate law about shareholders until the 1965 revision. The law also provides that if a company endangers public welfare and does not take corrective action, it can be dissolved by an act of state. ${ }^{242}$ Despite the relatively recent recognition that shareholders represent an important constituency, corporate law in Germany makes it abundantly clear that shareholders are only one of the many stakeholders on whose behalf the managers must operate the firm. ${ }^{243}$

Large firms with more than 500 employees are required to have a two-tier board structure: a supervisory board (Aufsichstrat) that performs the strategic oversight role and a management board (Vorstand) that performs an operational and day-to-day management oversight role. ${ }^{244}$ Membership overlaps be-

236. See Organization For ECON. COOPERATION AND DEV., ORgANiZATION FOR ECONOMIC COOPERATION AND DEVELOPMENT ECONOMIC SURVEYS: GERMANY 87 (1995) [hereinafter OECD GERMANY].

237. See LGT GUIDE TO WORLD EQUiTY MARKETS 1997500 (1997).

238. See OECD GERMANY, supra note 236.

239. For stock market data, see InTERnATIONAL Fin. CORP., EMERGING STOCK MARKETS FACTBOOK 17 (1998) [hereinafter IFC]. For GDP data, see INTERNATIONAL MONETARY FUND, INTERNATIONAL FINANCIAL STATISTICS 315, 397, 745 (July 1998) [hereinafter IMF].

240. See OECD GERMANY, supra note 236, and accompanying text.

241. Vagts, supra note 207, at 40 (quoting German corporate law).

242. See id. at 40-41.

243. See OECD GERMANY, supra note 236, at 84. A report in Financial Times notes that there is no phrase in the German language for the words "shareholder value." See Stefan Wagstyl, Crumbs from the Table, FIN. TIMES, Sept. 25, 1996, at 27.

244. See OECD GERMANY, supra note 236, at 86. 
tween the two boards are prohibited, and membership overlaps between boards of multiple corporations are restricted and rare. ${ }^{245}$ The supervisory board performs the watchdog role and is responsible for appointment and oversight of the management board. In firms with more than 2,000 employees, half of the supervisory board must consist of employees of the firm; the other half consists of shareholder representatives. ${ }^{246}$ The chairperson of the supervisory board is, however, typically from the shareholder side and has the tie-breaking vote. ${ }^{247}$ The management board consists almost entirely of the senior management of the company. ${ }^{248}$ Thus, board members tend to possess technical skills related to the product and considerable firm- and industry-specific knowledge. The essence of this two-tiered board structure is the explicit representation of stakeholder interests other than of shareholders: no major strategic decisions can be made without the cooperation of employees and their representatives.

Management compensation in German companies is usually in the form of fixed salaries and bonuses. The provision of stocks or stock options as part of the top-management's remuneration package is rare. In 1997, CEOs of listed German companies earned about half of what their American counterparts earned. $^{249}$ Unlike in the United States, the compensation of German board members must be approved by shareholders. German corporation law stipulates that such compensation must be reasonable and in conformity with the financial situation of the firm. ${ }^{250}$ Careers are often built up from the ground level and are focused on building asset-specific skills, through the extensive apprenticeship system that is used to train workers and managers in Germany.

The ownership structure of equity differs quite substantially from that observed in Anglo-American firms. Approximately fourteen percent of the shares are owned by banks, and about forty percent by other German corporations; both constituencies hold virtually nothing in the United States. ${ }^{252}$ Intercorporate shareholdings are common and difficult to disentangle from publicly

245. See Stephen Prowse, Corporate Governance in an International Perspective: A Survey of Corporate Control Mechanisms Among Large Firms in the United States, the United Kingdom, Japan, and Germany, BANK FOR INTERNATIONAL SETTLEMENTS ECONOMIC PAPERS NO. 41, 43 (July 1994).

246. See id.

247. See id. The ratio of non-employee to employee representation in companies with fewer than 2,000 employees is two-to-one. For more details on German boards, see MITSUHIRO FUKAO, FINANCIAL INTEGRATION, CORPORATE GOVERNANCE, AND THE PERFORMANCE OF MUlTiNATIONAL CORPORATIONS 100-01 (1995); Alfred F. Conrad, Corporate Constituencies in Western Europe, 21 Stetson L. ReV. 73, 74-80 (1991); Mark J. Roe, German "Populism" and the Large Public Corporation, 14 INT'L REV. L. \& ECON. 187 (1994); Prowse, supra note 245, at 43; Roe, supra note 233; Vagts, supra note 207.

248. The management board consists of managing directors, who are usually functional heads from within the company. See Philip Glouchevitch, Juggernaut: The German Way of Business: WHY IT IS TRANSFORMING EUROPE-AND THE WORLD 136 (1992); see also ROBERT LIGHTFOOT \& W. CARl Kester, Note on Corporate Governance Systems: The United States, Japan, AND GERMANY 10 (1991).

249. See MURPHY, supra note 10, at tbl.4.

250. See FUKAO, supra note 247, at 16-17.

251. See id. at 59.

252. See OECD GERMANY, supra note 236 , at 88. 
available data sources. Seventeen percent of the equity is owned by households ${ }^{253}$-compared to approximately fifty percent in the United States ${ }^{254}$-and this proportion has declined steadily since the $1960 \mathrm{~s}^{255}$ Ownership is concentrated: roughly twenty-five percent of the listed German firms have a single majority shareholder, and such majority holdings account for about sixty-five percent of the value of all listed stock. ${ }^{256}$

Importantly, a substantial portion of equity is in the form of bearer, rather than registered, stock. ${ }^{257}$ As a result, such equity is left on deposit with the hausbank of the corporation, which handles matters such as dividend payments and record keeping. ${ }^{258}$ German law allows banks to vote such equity on deposit by proxy, unless depositors explicitly instruct banks to do otherwise. ${ }^{259}$ Inertia appears to work in favor of banks having these proxy votes. As a result, banks directly or indirectly control a large portion of the equity in German companies. In a study of large, non-majority-owned firms in Germany reported by the Organization for Economic Cooperation and Development ("OECD"), Baums and Fraune found that nearly eighty-five percent of the voting shares in 1992 were controlled by banks and their associated investment funds. ${ }^{260} \mathrm{Com}-$ pounding the influence and the controlling role of banks is the provision in many company charters that non-bank shareholders may not exercise more than five to ten percent of the total votes regardless of the proportion of shares they own. ${ }^{261}$ Further, even when the shares are listed on an exchange, it is not uncommon practice for German corporations to list only non-voting shares. ${ }^{262}$

Turning to financing patterns, German companies, taken as a whole, are somewhat more leveraged than their American counterparts. Gross debt-tototal book assets was sixty percent in 1992, compared to fifty-one percent for

253. See id. at 90 tbl.25.

254. See 1997 ABSTRACT, supra note 52, at 524 tbl.808. (The exact percentage for the United States in 1990 was $49.7 \%$; the proportion had declined slightly to $47.4 \%$ by 1996 .)

255. See id.; Deutsche Bundesbank, COMPARISONS OF THE PROVISIONS OF Business ENTERPRISES IN SELECTED EC COUNTRIES WITH OWN FUNDS, DEUTSCHE BundESBANK MONTHLY REP. (Oct. 1994); OECD GERMANY, supra note 236, at 90.

256. See OECD GERMANY, supra note 236, at 89.

257. See FUKAO, supra note 247 , at 27 . In 1988 , approximately $40 \%$ of the market value of German shares was thus deposited with German banks, according to LIGHTFOOT \& KESTER, supra note 248 , at 11.

258. See OECD GERMANY, supra note 236, at 95 (noting that the system is that smaller share owners typically deposit their shares with banks, which prior to general meetings are required to ask depositors of shares about their desires concerning the exercise of associated voting rights but, in cases when shareholders have explicitly authorized the bank to vote on their behalf but have not given specific instructions, are allowed to vote in accordance with their own proposals).

259. See FUKAO, supra note 247, at 27.

260. See OECD GERMANY, supra note 236, at 95; T. Baums \& C. Fraune, Institionelle anleger und publikumsgessellschaft: Eine empirische untersuchung (Institut for Handels-unds Wirtschaftsrecht an der Universit Osnabrck Working Paper, 1992).

261. Banks, however, are exempt from this requirement. See FUKAO, supra note 247, at 108-09.

262. See GlOUCHEVITCH, supra note 247, at 93. Glouchevitch notes that the Frankfurt exchange lets companies list only non-voting shares, thus allowing controlling interests to be kept in private hands. However, he also notes that this practice is prevalent with only the smaller German companies. 
U.S. firms. ${ }^{263}$ But leverage is inversely related to size: Debt-to-asset ratios are much higher for the small- and medium-sized enterprises. Gross debt as a percentage of total assets in sample German companies averaged forty-five percent, but the breakdown was seventy-five percent for smaller companies, sixtynine percent for medium-sized companies, and forty percent for large companies. $^{264}$ The one notable difference between the leverage of Anglo-American and German firms is, however, the reliance of German firms on bank or intermediated debt, and the relatively minor role played by market debt instruments. ${ }^{265}$ Bank financing of long-term debt has averaged around fifty percent, and this percentage has remained fairly stable during the past two decades. ${ }^{266}$ The other notable difference is the reliance on internal financing. During the period 1984-92, German companies met more than seventy percent of their gross funding needs through internal financing. ${ }^{267}$ The relatively minor role of equity financing is explained partly by taxes and regulation. Until 1992, there was a one-percent tax on the value of all new equity issues, and secondary trading in equities was subject to a transaction tax. ${ }^{26}$

Dividend payout rules are designed to protect creditor interests. German law stipulates that dividends may not be paid out from paid-in capital, even if such paid-in capital includes a premium over the face value of equity. ${ }^{269}$ This provision makes it difficult for German firms to undertake share repurchases. Moreover, companies must retain a portion of their profits as reserves, serving as added security for creditors. ${ }^{270}$ Compared to U.S. firms, the quality of disclosure in German firms is poor. An OECD survey of disclosure quality states that, as of 1989, none of the German firms in their sample had complied fully with OECD disclosure guidelines. ${ }^{271}$ Moreover, the legal and regulatory framework for disclosure is considered relatively lax, compared to that in the United States. Accounting rules emphasize conservatism. For example, unrealized losses that are likely to be realized must be provided for, but unrealized

263. See Deutsche Bundesbank, West German Enterprises' Profitability and FiNANCING, DEUTSCHE BUNDESBANK MONTHLy REP. (Nov. 1992); see also OECD GERMANY, supra note 236 , at 92.

264. See OECD GERMANY, supra note 236, at 93; see also Deutsche Bundesbank, supra note 263.

265. See Prowse, supra note 245 , at 26 . The relatively minor role of market debt is explained by the severe restrictions placed by the German government on the issuance of such debt. Issuance of commercial paper and domestic bonds was discouraged until 1992 by complicated authorization procedures and transfer taxes. The issuance of foreign currency bonds was prohibited until 1990, and the issuance of Eurobonds required prior notification and was subjected to maturity restrictions. See id.at 26 tbl. 4. For more details, see M. TAKEDA \& P. TURNER, THE LIBERALIZATION OF JAPAN'S FINANCIAL MARKETS: SOME MAJOR THEMES (1992).

266. See OECD GERMANY, supra note 236, at 94.

267. See id.

268. See Prowse, supra note 245, at 26; see also Stephen Prowse, Corporate Finance in an International Perspective: Legal and Regulatory Influences on Financial System Development, ECON. REV., July-Aug., 1996, at 2.

269. See FUKAO, supra note 247, at 120.

270. See id.

271. See Prowse, supra note 245 , at 29 . The zero-compliance rate in Germany compares to $67 \%$ for U.S. firms and $75 \%$ for U.K. firms. See id. at 10 . 
gains may not be recognized. ${ }^{272}$ Similarly, tangible fixed assets are carried at cost, less depreciation, so that true asset values are understated, and marketable securities are carried at historical cost. ${ }^{273}$ Net income figures reported by German firms are suspect because of the extensive use of reserve accounting to build up hidden reserves; income-smoothing considerations tend to predominate. ${ }^{274}$ Until recently, Germany had no insider-trading laws; if insider trading was discovered, the penalty was simply to turn over the profits. ${ }^{275}$

No doubt owing to the concentration of ownership, the constraints imposed on stockholder voting and the control of the banks, the market for corporate control is poorly developed in Germany. Stephen Prowse reports that during the period $1985-89$, only $2.3 \%$ of the market value of listed stocks were involved in mergers and acquisitions, compared to more than forty percent in the United States. ${ }^{276}$ Even when corporate combinations take place, they tend to be friendly, arranged deals. Hostile takeovers and leveraged buyouts are virtually non-existent. ${ }^{277}$ There is, as yet, no commonly accepted formal takeover law, but there are informal guidelines. Antitakeover provisions, poison pills, and golden parachutes have not yet been employed in Germany.

Corporate restructurings tend to be private affairs with the hausbank playing the lead role, and most workouts in financial distress tend to be informal rather than court-based. ${ }^{278}$ The absence of court-based workouts is not surprising. Although there are both reorganization and liquidation provisions in German bankruptcy law, the law is skewed toward protecting creditor interests, and the absolute priority rule is strictly followed. ${ }^{279}$ Thus, there is a bias toward liquidations in bankruptcies that end up in courts or enter the formal workout process, ${ }^{280}$ a situation that stakeholders prefer to avoid unless absolutely necessary.

2. The Japanese Corporate Governance System. There are approximately 1,800 listed companies in Japan, ${ }^{281}$ and their collective market capitalization as a percentage of GDP was approximately fifty-seven percent as of $1997 .^{282}$ The hallmark of the Japanese industrial organization system is groups of networks

272. See OECD GERMANY, supra note 236, at 106.

273. See id.

274. See FUKAO, supra note 247, at 120-21.

275. See id. at 117-18.

276. See Prowse, supra note 245 , at 47.

277. Between 1945 and July 1999, there have been only three cases of completed hostile takeovers of non-financial corporations in Germany. Data for 1945 to 1994 (three hostile takeovers) are from Julian Franks \& Colin Mayer, Ownership, Control and the Performance of German Corporations 1 (London Business School Working Paper, Dec. 1997) (on file with authors). Data from 1994 to July 1999 (zero hostile takeovers) is based on the authors' analysis of the Securities Data Corporation Mergers and Acquisitions database (calculations on file with authors).

278. See FUKAO, supra note 247, at 123.

279. See id.

280. See id.

281. See LGT GuIDE TO WORLD MONEY MARKETS, supra note 237, at 266.

282. See IFC, supra note 239; IMF, supra note 239. 
of firms with stable, reciprocal, minority equity interests in each other, known as keiretsus. ${ }^{283}$ Although the firms in a keiretsu are typically independent, separate, joint stock companies, they tend to have relational and implicit contracts with each other on matters such as ownership, governance, and commercial contacts. Keiretsus can be vertical or horizontal. When the network of firms consists of a loose collection of firms from the supplier to the distributor chain, they are called vertical keiretsus; when the network consists of a loose collection of businesses in similar product markets, they are called horizontal keiretsus. The horizontal keiretsus typically include a large main bank that does business with all of the member firms. The main bank also holds minority equity positions in each of the member firms. ${ }^{284}$ Although the actual number of keiretsu firms is small relative to the total number of joint stock companies in Japan, they collectively represent about twenty-five percent of the total sales in the Japanese corporate sector and about fifty percent of the value of all listed stock in Japan. ${ }^{285}$

The structure of boards in Japan is similar to that in the Anglo-American system, with single-tier boards. ${ }^{286}$ However, a substantial majority of board members consist of company insiders, notably the current or former senior and middle management of the company. ${ }^{287}$ Thus, unlike the United States, outside directorships are rare. The one exception to outside directorships is the main banks. Their representatives usually sit on the boards of the keiretsu firms with whom they do business. ${ }^{288}$ Mitsuhiro Fukao reports that in 1989, banks collectively sent about 2,065 directors and auditors to 2,131 Japanese companies, which had a total of nearly 40,000 directors and auditors. ${ }^{289}$ Unlike the case of Germany where employees and sometimes suppliers tend to have explicit board representation, the interests of stakeholders other than management or the banks are not directly represented on Japanese boards. ${ }^{290}$

283. Fukao translates it as "a series of things organized to perform a function." FUKAO, supra note 247, at 2. For more details on the Japanese keiretsu, see generally W. CARL KESTER, JAPANESE TAKEOVERS: THE GlobAl CONTEST FOR CORPORATE CONTROL $54-55$ (1991); Erik Berglof \& Enrico Perotti, The Governance Structure of the Japanese Financial Keiretsu, 36 J. FIN. ECON. 259 (1994); David Flath, Shareholdings in the Keiretsu, Japan's Financial Groups, 75 REV. ECON. \& STAT. 249 (1993); Hesna Genay, Japan's Corporate Groups, ECON. PERSP. Jan.-Feb. 1991, at 20 (comparing Japanese keiretsus and independent firms); James R. Lincoln et al., Evolving Patterns of Keiretsu Organization and Action in Japan, in 20 RESEARCH AND ORGANIZATIONAL BEHAVIOR 303 (Barry M. Staw \& L.L. Cummings eds., 1998); James R. Lincoln et al., Keiretsu Networks \& Corporate Performance in Japan, 61 AM. SOC. REV. 67 (1996) (examining the relationship between keiretsu membership and profitability among 197 firms over a period of 24 years); Gilson \& Roe, supra note 19, at 894-95.

284. See Paul Sheard, The Main Bank System and Corporate Monitoring and Control in Japan, $11 \mathrm{~J}$.

ECON. BEHAV. \& ORG. 399, 402 (1989).

285. See LIGHTFOOT \& KESTER, supra note 248, at 6.

286. See Prowse, supra note 245 , at 42 .

287. Fukao notes that nearly $78 \%$ of Japanese directors are promoted from among employees. See

FUKAO, supra note 247, at 14.

288. See id. at 25.

289. See id.

290. See Organization For ECON. CoOperation AND DeV., FinAnCial MARKET Trends No. 62, Dec. 1995, at 23. 
Concrete evidence on the role and effectiveness of Japanese boards in disciplining management is unavailable, but, in addition to the boards, three other constituencies seem to perform important monitoring roles. Banks play an oversight role, being closely involved in matters of top-management selection and replacement, advice, commercial contacts, and intervention in times of financial distress. ${ }^{291}$ Evidence suggests that involuntary top-management turnover is higher following poor financial and stock price performance in Japanese companies with extensive bank involvement. ${ }^{292}$ The other common governance feature among vertical keiretsu companies with a supplier network is the kyoryokukai, or suppliers' clubs, that meet regularly to exchange ideas and information on people and firms with whom they do business. ${ }^{293}$ These clubs act as a check on management. ${ }^{294}$ The third source of top-management monitoring is the Presidents' Club, which consists of the presidents of the member firms of a keiretsu who meet at regular intervals, and sometimes informally, to discuss activities within their group. ${ }^{295}$ Shareholders can theoretically remove directors by a simple majority vote, but this rarely happens. ${ }^{296}$

Share ownership in Japan is concentrated and stable. Although Japanese banks are not allowed to hold more than five percent of a single firm's stock, a small group of four or five banks typically controls about twenty to twenty-five percent of a firm's equity. ${ }^{297}$ The largest bank shareholder also is usually the largest debtholder in the company. ${ }^{298}$ Individual share ownership in Japan, like in Germany, has steadily declined from about fifty percent in the 1950s to

291. See generally KESTER, supra note 283, at 69-74 (discussing the concept of selective intervention); W. Carl Kester, The Hidden Cost of Japanese Success, 3 J. APPLIED CORP. FIN. 90 (1991) (discussing the role of bank oversight in corporate governance).

292. See Jun-Koo Kang \& Anvil Shivdasani, Firm Performance, Corporate Governance, and Top Executive Turnover in Japan, 38 J. FIN. ECON. 29, $41-49$ (1995); Steven N. Kaplan \& Bernadette A. Minton, Appointments of Outsiders to Japanese Boards: Determinants and Implications for Managers, 36 J. FIN. ECON. 225, 243, 246-47 (1994).

293. See LIGHTFOOT \& KESTER, supra note 248 , at 8.

294. See id.

295. See id. at 68-69.

296. See FUKAO, supra note 247 , at 15.

297. See id. at 22 tbl.2-4; see also Jonathan R. Macey \& Geoffrey P. Miller, Corporate Governance and Commercial Banking: A Comparative Examination of Germany, Japan, and the United States, 48 STAN. L. REV. 73, 82-83 (1995).

298. In his sample of Japanese firms, Prowse reports that in $45 \%$ of the firms, the largest shareholding bank is also the largest debtholder, accounting for about $25 \%$ of the firm's debt, on average. See Stephen Prowse, The Structure of Corporate Ownership in Japan, 47 J. FIN. 1121, 1123, 1126 (1992). The five largest debtholders in a firm had, on average, approximately $50 \%$ of the firm's debt and about $20 \%$ of its equity. See id. at 1128 . Another $25 \%$ of the equity in Japanese companies is accounted for by inter-corporate stockholding, and these cross-holdings are rarely, if ever, sold. The agreement not to sell inter-corporate holdings is unwritten and implicit. Indeed, the $25 \%$ of equity as inter-corporate holdings is a number that remained remarkably stable during the past two or three decades. It is remarkable because the proportion of inter-corporate holdings barely budged during the period 1985-89, when the Japanese stock market rose by about $150 \%$ and when we may have expected an increase in such holdings, and during the period 1989-94, when the stock market declined by about $60 \%$ and a decrease in such holdings may have been expected,. Insurance companies in Japan hold another $20 \%$ of the equity; they may not own more than $10 \%$ of the equity in a single company. See David E. Weinstein, FDI and Keiretsu: Rethinking US and Japanese Policy, in EFFECTS OF US TRADE PRotection AND PRomotion Policies 91 tbl.4.1 (Robert C. Feenstra ed., 1997) 
about twenty percent at present. ${ }^{299}$ Thus, in a typical Japanese firm, approximately two-thirds of the equity is owned by banks, insurance companies, and other corporations. $^{300}$ This proportion has remained fairly stable over the past fifteen years, and these closely held shares rarely, if ever, make it into the financial marketplace.

As in Germany, the market for corporate control in Japan is relatively inactive. Mergers and acquisitions were slightly more than three percent of total market capitalization during the period $1985-89,{ }^{301}$ and all were friendly transactions. Although there are, on average, about 450 mergers or acquisitions involving Japanese companies annually, about half of these consist of Japanese companies acquiring non-Japanese companies, and most of the remaining consist of small deals among Japanese companies. ${ }^{302}$

Antitakeover defenses, poison pills, and golden parachutes are rarely present in corporate charters or bylaws. The words used to describe takeovers in Japanese-miurisuru (to sell one's body), baishu (bribery), and nottori (hijack) - suggest a cultural aversion to takeovers. Part of the reason for this cultural aversion appears to stem from the fact that organized crime groups such as the yakuza are often involved in stock-cornering, greenmailing, and the occasional takeover attempt. ${ }^{303}$ The late 1980s saw successful greenmailings of a number of Japanese companies, including some well-known companies such as Toyota, Fujiya, and Mitsui Mining. ${ }^{304}$ Although the Japanese Commercial Code prohibits firms from repurchasing their own shares, ${ }^{305}$ the frequency of greenmailings suggests that many Japanese firms seem to have overcome this provision in the law quite successfully. ${ }^{306}$

Corporate restructurings in Japan tend to be private and informal. Courts or lawyers are rarely used, with the main bank usually taking the lead role in these transactions. ${ }^{307}$ Restructurings also appear to be accompanied by considerable top-management replacement. ${ }^{308}$ Bankruptcy law in Japan has both liquidation and rehabilitation provisions, and, as in Germany, the law is skewed

299. See OECD GERMANY, supra note 236 , at 88.

300. In 1990, insurance companies held $19.6 \%$ of common stock in Japanese companies. See id. at 88 tbl.23. According to this source, banks owned $18.9 \%$, and non-financial enterprises owned $24.9 \%$, thus totaling $63.4 \%$ among these three constituencies. If pension funds and other financial institutions are added, the total would be approximately $73 \%$.

301. See Prowse, supra note 245, at 47.

302. See KESTER, supra note 283, at 83-84, exhibit 4-1 (noting that "deal flow in Japan involves combinations of much smaller size [compared to the U.S.]").

303. See id. at 245.

304. See id. at 245, 247-48 (listing 41 greenmailings during the period 1976-88). Regarding the involvement of the underworld in corporate Japan, see Corporate Japan Hit By Gangsters, FIN. TIMES, Apr. 26, 1997, at 23; Fifth of Japanese Companies Admit to Bad Behavior, FIN. TIMES, Apr. 11, 1997, at 6 .

305. See FUKAO, supra note 247, at 114. There are severe restrictions, as in Germany, on firms' payout policies vis-à-vis their paid-in capital. See id.

306. See supra note 304 and accompanying text.

307. See LIGHTFOOT \& KESTER, supra note 248, at 8-9.

308. See Kang \& Shivdasani, supra note 292. 
toward protecting creditors' interests. ${ }^{309}$ However, there is no evidence of a bias toward liquidation in restructurings that result in formal workouts.

Although their leverage has been decreasing over time, Japanese companies tend to be, on average, more leveraged than their U.S. or German counterparts. Gross debt-to-total book assets was about eighty percent in 1992, and fifty-seven percent of the debt was bank or financial institutionintermediated. $^{310}$ During the period 1984 to 1992, Japanese firms funded more than fifty percent of their gross funding needs through debt. ${ }^{311}$ Retained earnings play a smaller role than in Germany and the United States. About forty percent of the gross funding needs during the period 1984 to 1992 were accounted for by internally generated funds. ${ }^{312}$ There were considerable restrictions during the 1970s and 1980s on a firm's ability to raise market debt such as commercial paper, domestic bonds, and Eurobonds. ${ }^{313}$ Moreover, until 1988, there was a heavy transactions tax on equity transfers. ${ }^{314}$ As these restrictions have been eased, however, Japanese firms have been undertaking more issuances of market debt, especially in the Euromarkets, driven, in part, by a desire to reduce their dependence on the main banks and their bank debt. ${ }^{315}$ In the early 1980s, only 250 Japanese firms had issued bonds outside Japan; by the late 1980 s, the number had grown to more than $1,200 .^{316}$ Rules on dividend payouts and share repurchase are similar to those in Germany, although Japanese firms are able to overcome the rules on share repurchases with some ease.

Internal management styles and control systems in Japanese firms rely on building long-term, consensus-based relationships and are characterized by a great deal of informal interactions, personal relations, and information-sharing among relatively culturally homogeneous individuals. There is an apparent reliance on trust, reputation-building, and face-saving considerations as the basis for contracting. ${ }^{317}$ The corporation is seen by its employees as much as a social entity as an economic entity. Companies rely on basic agreements and face-toface contacts to resolve issues. Legal contracts or stipulations with stakeholders are rare. Japanese firms in the larger, organized sector of the economy emphasize lifetime employment and building human capital by maximizing assetspecific and relation-specific skills. ${ }^{318}$ Lateral inter-functional transfers of man-

309. See FUKAO, supra note 247, at 123 (noting that banks are usually involved in the informal workout process and that the "protection of collateral is strong").

310. See OECD GERMANY, supra note 236, at 92.

311. See id. at 91.

312. See id.

313. See Prowse, supra note 245, at 26 tbl.4.

314. See id.

315. See id. at 58 (citing Hoshi et al., The Role of Banks in Reducing Costs of Financial Distress in Japan, 27 J. FIN. ECON. 67 (1990) (noting that many Japanese firms were reducing their dependence on banks and resorting to external finance during the 1980s).

316. See The New State of Corporate Japan, Survey: International Finance, ECONOMIST, Apr. 27, 1991, at 32, 36.

317. See generally KESTER, supra note 283.

318. See generally Masahiko Aoki, Toward an Economic Model of the Japanese Firm, 28 J. ECON. LITERATURE 1 (1990) (discussing the structure of Japanese firms). 
agers and horizontal information flows among functions and departments, both within the firm and across firms within the network, are common. Upward mobility within Japanese organizations is carried out through a process of moving up through a cross-functional spiral rather than a series of promotions within a particular functional area. ${ }^{319}$ Management compensation, including that of top management, relies on salaries and bonuses. ${ }^{320}$ Stocks or stock options are rarely used as a basis for remuneration. Total compensation of top managers, including bonuses, is about six to eight times the compensation of the most highly paid blue-collar worker and about seventeen times that of the average worker. ${ }^{321}$ A managerial labor market along the U.S. style, especially for mid-career workers, is thin. ${ }^{322}$

Disclosure quality, although considered superior to that of German companies, is poor relative to that of U.S. firms. Although there are rules against insider trading and monopolistic practices, the application of these laws is, at best, uneven and inconsistent. As with German firms, accounting rules emphasize conservatism. ${ }^{323}$

3. Assessment of the German and Japanese Governance Systems. Although there are some apparent differences, there is a surprising degree of similarity between the German and Japanese governance systems. Similarities include the relatively little reliance on external capital markets; the minor role of individual share ownership; the significant role of institutional and inter-corporate ownership, which is often concentrated; relatively stable and permanent capital providers; boards comprising functional specialists and insiders with knowledge of the firm and the industry; the relatively important role of banks as financiers, advisers, managers, and monitors of top management; the increased role of leverage with emphasis on bank financing; informal as opposed to formal workouts in financial distress; the emphasis on salary and bonuses rather than stocks and stock options as the basis for top- management compensation; the relatively poor disclosure from the standpoint of outside investors; and conservatism in accounting policies. Moreover, both the German and Japanese governance systems emphasize the protection of employee and creditor interests at least as much as the interests of shareholders. ${ }^{324}$ The market for corporate control as a credible disciplining device is largely absent in both Japan and Germany, as is the need for takeover defenses. The governance system itself may be considered a de facto poison pill.

The focus of the governance problem in the United States and, more generally, the Anglo-American system, appears to implicitly address the agency

319. See id. at 11.

320. See OECD GERMANY, supra note 236, at 107 fig. 27.

321. See FUKAO, supra note 247 , at 17.

322. See id. at 57.

323. See id. at 119-20.

324. One difference is that employees play less of a direct role in Japan as compared to the German system, but suppliers play a more important role in Japan. 
problems that arise in the context of information asymmetries and selfinterested behavior among managers, equityholders, and debtholders. In Germany and Japan, the governance systems appear to be focused on addressing problems of transaction efficiency and the appropriate scope of the firm. ${ }^{325}$ In the U.S. governance system, the solution to problems of transaction efficiency and firm scope is approached through the lens of the choice between markets-arms-length dealings--and hierarchies--vertical or horizontal integration--while in the German and Japanese governance systems, the solution to agency problems between management, debt, and equity appears to be addressed by attempts to bundle or commingle the three constituencies into one. ${ }^{326}$ The U.S. approach to governance is comparatively contractarian in its scope and intent, while the German and Japanese approaches to governance are relatively communitarian in their scope and intent. As noted above, the firm in Germany and Japan is considered as much of a social entity as it is an economic entity. In the words of OECD, the U.S. system is an outsider system of governance, while the German and Japanese systems are insider systems of governance. ${ }^{327}$

The attributes of German and Japanese governance identified aboveemphasis on lifetime employment; a significant governance role for employees and suppliers; concentrated and stable equity ownership with relatively permanent providers of capital; bank involvement; insiders with experience on the board; and emphasis on informal and face-to-face, rather than formal, contractual, court-based relationships-have not been created in an institutional and historical vacuum. The very fact that these attributes have evolved and survived over time in two relatively successful corporate economies prima facie suggests that they must, indeed, have their efficiency aspects.

The emphasis on lifetime employment and the employee role in governance must surely give employees a greater incentive to develop and supply firmspecific human capital. ${ }^{328}$ It also encourages greater employee loyalty to corporations and perhaps helps to create a more engaged labor force that is willing to contribute to a team effort rather than competitive relationships within firms. ${ }^{329}$ Employees also may have a greater incentive to provide value-saving advice

325. Kester, Gilson, and Roe refer to the latter set of issues as the workings of a contractual--as opposed to corporate--governance system. W. Carl Kester, Industrial Groups as Systems of Contractual Governance, 8 OXFORD REV. ECON. POL'Y 24 (1992); Gilson \& Roe, supra note 19, at 874.

326. See KESTER, supra note 283, at 32-34 (noting that "an important effect of cross-shareholding arrangements ... is to commingle the types of claims against a company held by its various stakeholders," and the economic benefits from such commingling are "a reduction in the frictions that might normally arise among various stakeholder groups if each owned a separate and distinct claim").

327. See OECD GERMANY, supra note 236, at 28.

328. See FUKAO, supra note 247, at 6 (arguing that "it is easier for the management of Japanese and German companies than it is for the management of U.S. and U.K. companies to maintain longterm implicit contracts with employees"); see also OECD GERMANY, supra note 236, at 108 (noting that the "greater stability and consensus in labor relations may increase the incentives for investment in human capital both on the part of firms and workers themselves"); Kester, supra note 325, at 35 (arguing that "the distribution of equity ownership among significant corporate stakeholders facilitates implicit contracting and the realization of transactional efficiencies").

329. See Roe, supra note 233, at 1984 (noting that "loyalty to real people may motivate better than legally mandated loyalty to an abstraction"). 
and may be more willing to make concessions in times of economic or financial distress. ${ }^{330}$ Analogous arguments, such as the greater ability to deal with quality-control issues and to develop firm-specific arrangements, could be logically made with respect to suppliers.

Stable, concentrated, relatively permanent, cross-owned equity capital providers also play a positive role. Mark J. Roe argues that large shareholders' "ongoing involvement means that they do not need time to move up from the bottom of a learning curve and can intervene quickly when crises hit." ${ }^{, 31} \mathrm{He}$ goes on to argue that block ownership of shares facilitates a great deal of mutual monitoring and deters opportunism with multiple blocks checking each other, impelling managerial action, and facilitating power sharing, not domination. $^{332}$ Mitsuhiro Fukao argues that such an equity ownership structure could lower the cost of equity capital. ${ }^{333}$ In addition, the preponderance of insiders on the board encourages a great deal of information sharing and brings firm- and industry-specific knowledge to the governance process. ${ }^{334}$ Other implications of stable, permanent equity ownership are obvious. Managers do not need to constantly look over their shoulders worrying about corporate raiders. They can manage for the long run and can more effectively withstand the pressures to manage on a quarter-to-quarter basis.

Quite apart from the lending and the direct intervention roles they play, banks also may facilitate the governance process. They are likely to have a great deal of access to inside information and hence can perform a monitoring role very effectively, ${ }^{335}$ the bundling of debt and equity claims with the same capital providers eliminates, or at least mitigates, the potential agency problems that can arise between debtholders and equityholders; ${ }^{336}$ and restrictions on cash distributions (for example, on share repurchases and dividend payments) can lower the cost of debt because creditors' positions are made safer. ${ }^{33}$ Finally, it is no surprise, given the governance role of the banks, that resolution

330. Germany has among the lowest levels of strike activity among the OECD group of countries, and an extremely high proportion of new recruits, $71 \%$, receive formal training from employers through apprenticeship systems "represent[ing] a considerable investment by both firms and workers (through lower pay), partly related to the expected long tenure." OECD GERMANY, supra note 236, at 108 . The report also points out that in Germany, employment adjustment to output fluctuations happens more through the number of hours worked, compared to the United States where the number employed bears a much larger part of the adjustment. See id. at 108-09.

331. Roe, supra note 233, at 1980.

332. See id.

333. See FUKAO, supra note 247 , at 6.

334. See KESTER, supra note 283 , at 35 ("[D]irectors of an industry group company mirror the company's most important long term stakeholder relationships. They generally bring to the position considerable managerial expertise, thorough knowledge of the company's businesses, and a deep appreciation of the company's contractual relationship with its major stakeholders.").

335. See id. at 35-36; see also Roe, supra note 233, at 1984 (arguing that bank ownership can actually increase managerial accountability).

336. See Roe, supra note 233, at 1986 (pointing out that such commingling of claims can create a disincentive to adopt high-variance strategies that can benefit stockholders at the expense of creditors and other stakeholders).

337. See FUKAO, supra note 247, at 6 . 
of financial distress in both Germany and Japan is a much more informal process compared to a country such as the United States. ${ }^{338}$

Clearly, the cooperation among firms under the Japanese system permits a degree of integration that is not possible under U.S. antitrust laws. The coordination along the value chain as well as consultation with competitors must enhance economic efficiency, although the lack of competition may stifle the incentives to exploit these efficiencies.

a. A Critique of German and Japanese Governance. The stakeholder orientation and the relatively communitarian features of German and Japanese corporate governance are not, however, without their costs. The bank-centered nature of governance in both Germany and Japan poses a number of risks. Unlike the case of equity investors who, in both theory and practice, are concerned with the systematic risk of a particular asset vis-á-vis a welldiversified portfolio, undiversified debtholders are concerned about their credit risk, which is determined by an asset's total risk. ${ }^{339}$ Focus on total risk creates a number of adverse incentive problems on both the asset side and the liability side of a firm's balance sheet. On the asset side, it can create the tendency to reduce total risk through corporate diversification or by ex ante constraining investment that maximizes share value. ${ }^{340}$ It also can induce a bias against startup kinds of businesses because a focus on total risk minimization can lead to entrepreneurial risk-aversion in investment choices. In a related vein, it is inherent in the nature of bank credit to focus on asset types that are collateralizable and tangible, thus biasing investment choices away from asset types that are intangible and, hence, non-collateralizable. The latter type of asset typically tends to be more research-and-development- and human-capital intensive. As previously argued, comparative advantages in global product markets depend critically on such assets. ${ }^{341}$ On the liability side of a firm's balance sheet, a focus on total risk reduction can lead to excessive hedging and excessive investment in insurance. It also can focus a firm's accounting policies toward income-smoothing, rather than value-creating, considerations.

The heightened roles of both employees (Germany) and suppliers (Japan) in corporate governance can lead to inflexibility in sourcing strategies, labor markets, and corporate restructurings (for example, asset sales, downsizing,

338. See Michael Bradley \& Michael Rosenzweig, The Untenable Case for Chapter 11, 101 YALE L.J. 1043 (1992). For a comparative discussion of bankruptcy laws in Germany, the United Kingdom, Japan and the United States, see Bankruptcy Law: The Sticky End, ECONOMIST, Feb. 24, 1990, at 77 (comparing the bankruptcy laws in the major industrialized economies and arguing the need for a more uniform system); see FUKAO, supra note 247, at 122-24.

339. Systematic risks are the risks that remain in a well-diversified portfolio of stocks, whereby all the unsystematic risks have been diversified away. Rational stock investors are assumed to hold welldiversified portfolios and, hence, bear only the systematic portion of the total risk--the total risk is the sum of systematic and unsystematic risks--in stock returns. See, e.g., Richard BREALEY \& STEWART MEYERS, PRINCIPLES OF CORPORATE FINANCE (1996).

340. This is the underinvestment incentive recognized in the finance literature. See, e.g., Stewart C. Myers, Determinants of Corporate Borrowing, 5 J. FIN. ECON. 147 (1977).

341. See supra note 73 and accompanying text. 
spin-offs, and deconglomeration). In contrast to U.S. firms, therefore, firms in Germany and Japan are less likely to be able to move quickly to meet competitive challenges from the global product-market arena. ${ }^{342}$ The employees' role in governance also may have an adverse impact on labor costs, further eroding firms' competitive positions in a global economy. The suppliers' role in governance, as in the case of the vertical keiretsu in Japan, can lead to potential problems of implicit or explicit vertical restraints to competition and, hence, antitrust problems. In addition, a firm's globalization strategy might be seriously hindered because an entire vertical chain of relationships is less portable across borders than within a stand-alone firm. Moreover, as fixed claimants to a firm's revenue stream, both employees and suppliers have an incentive to skew corporate decisions toward total-risk-minimization strategies. This exacerbates the similar incentives that follow from the bank's role in governance.

The nature of equity ownership -intercorporate holdings as permanent and stable providers of equity capital - also may pose problems. Given the differences in laws, especially in the Anglo-American system of governance, the ownership structures are likely to be illegal in some countries and therefore less likely to be portable across borders. They are also inconsistent with the inexorable trends toward the globalization of financial markets, with the increasing role played by private pension and mutual funds. Because such structures may be biased toward external-capital-market dependence and because current owners may not want to dilute their ownership, stable crossholdings create artificial capital constraints. The perceived stability in capital provision also may lead managers to undertake excessive investments in capacity and may create the tendency for product and brand proliferation as well as uneconomical diversification. ${ }^{343}$ Finally, these equity ownership structures militate against the development of a market for corporate control, which arguably is an important source of managerial discipline in the Anglo-American system.

The emphasis on lifetime, or at least long-term, employment may induce its own biases-it obviates any role for the managerial labor market as a disciplining mechanism. Further, it biases the firm toward corporate strategies that emphasize survival and market-share maximization, rather than share-value and profit maximization, because of the obvious benefits of job stability that such strategies entail. Lifetime/long-term employment strategies also hinder inter-corporate mobility and inter-corporate socialization, thereby potentially

342. See generally Robert Comment \& Gregg A. Jarrell, Corporate Focus and Stock Returns, 37 J. FIN. ECON. 67 (1995) (examining deconglomeration evidence that speaks to the flexibility of the U.S. system). See generally Gerald F. Davis et al., The Decline and Fall of the Conglomerate Firm in the 1980s: The Deinstitutionalization of an Organizational Form, 59 AM. SOC. REV. 547 (1994).

343. See KESTER, supra note 283, at 39 (observing this to be true in the Japanese setting); see also Kester, supra note 291, at 219-35. Recent work related to the Korean governance system with their chaebols, which are industrial groupings similar to the keiretsu in Japan, finds that chaebol firms, too, have a tendency to overinvest, that is, they invest more than non-chaebol firms, despite relatively poor growth opportunities. See Hyun-Han Shin \& Young S. Park, Financing Constraints and Internal Capital Markets: Evidence from the Korean Chaebols (Working Paper, 1999) (on file with the authors). 
stunting the development of industries that rely on cross-fertilization of ideas and human capital (for example, Silicon Valley-type industries).

Recent and growing empirical evidence suggests that many of these theoretical risks are, in fact, real. Labor costs in manufacturing both in Germany and Japan have seriously eroded the competitiveness of their firms in the global marketplace. For example, as of the end of 1996, the average German manufacturer paid about thirty-two dollars per hour of employee work, the Japanese manufacturer paid about twenty-one dollars, while in the United States, the comparable figure was about $\$ 17.70 .^{344}$ Inflexible labor markets have contributed to the historically high unemployment rates in Europe during the past few years, while the unemployment rate in the United States has been steadily declining. ${ }^{345}$ During the period 1984 to 1996 , the U.S. economy created 22.3 million jobs--20.5 million in the private sector and 1.8 million in the government sector--for an employment growth of nearly twenty-five percent--twenty-seven percent growth in the private sector and more than twelve percent growth in the government sector. ${ }^{346}$ In comparison, for the roughly similar period 1984 to 1995 , the European Union witnessed an employment growth of just $0.6 \%$ in the private sector and a decline of $4.2 \%$ in the government sector, thus increasing overall unemployment, given the growth in the labor force during this period. ${ }^{347}$ A recent report of the OECD states that labor productivity across the board in Germany is about eighty percent of that in the United States, while labor productivity in Japan is about sixty-one percent of that in the United States. ${ }^{348}$

As previously noted, private mutual funds play an extremely small role in the equity markets of both Germany and Japan, as do private pension funds. Pension funds in the United States held more than four trillion dollars in assets in 1995 (fifty-five percent of GNP), and the U.K. funds had $\$ 814$ billion in assets (seventy-three percent of GNP), compared to seventy billion dollars in pension fund assets in Germany (3.2\% of GNP) and forty-one billion dollars in France $\left(3.4 \%\right.$ of GNP). ${ }^{349}$ More than eighty percent of the U.K. pension fund

344. See Office of Productivity and Technology, Bureau of Labor Statistics, U.S. DEP'T OF LABOR, INTERNATIONAL COMPARISONS OF HOURLY COSTS FOR PRODUCTION WORKERS IN MANUFACTURING, 1975-1996, tbl.2 (June 1997).

345. See generally OECD, THE OECD JOBS STUdy: EVIDENCE AND EXPLANATIONS: PART 1: LABOUR MARKET TRENDS AND UNDERLYING FORCES OF CHANGE (1994). During the period 1980 to 1995 , the unemployment rate in the Unites States declined from $7.1 \%$ to $5.6 \%$, while it went up from $2.8 \%$ to $6.5 \%$ in West Germany and from $2.0 \%$ to $3.2 \%$ in Japan. See BUREAU OF CENSUS, U.S. DEP'T OF COMMERCE, STATISTICAL ABSTRACT OF THE UNITED STATES 845 (1997).

346. The figures are calculated from the data in ORGANIZATION FOR ECON. COOPERATION AND DeV., NATIONAL ACCOUNTS-DETAILED TABLES 71, tbl.15 (1998) (on file with authors).

347. The figures are calculated from the STATISTICS Directorate, 33 HistoricAl STATISTICS1960-1995 tbls.1.12, 1.13 (1997) (on file with authors).

348. See Organization for ECON. CoOperation And Dev., 2 TeChNOlOgy Productivity AND JOBS CREATION 32 tbl.2.1 (1996). There is also evidence that total manufacturing productivity growth during the 1990s in Germany and Japan has substantially lagged behind that in the United States. See BUREAU OF CENSUS, supra note 345, at 847.

349. Data for pension fund assets in the United States, United Kingdom, and Germany are found in INTERNATIONAL MONETARY FUND, INTERNATIONAL CAPITAL MARKETS: DEVELOPMENTS, Prospects, AND Key PoliCy Issues 184 (Sept. 1998). For GNP data, see BuREAU OF CENSUS, su- 
investments were in equity, compared to thirteen percent in France and eleven percent in Germany. ${ }^{350}$ The negligible roles that the market for corporate control and the managerial labor markets play in both Germany and Japan have already been noted.

A more serious, longer-term competitive issue for Germany and Japan may be the bias in the governance system against start-ups and research-anddevelopment- ("R\&D") and human-capital-intensive industries. The average age of a listed firm in the United Kingdom is about eight years. ${ }^{351}$ In the United States, the figure is fourteen years for stocks listed on the New York Stock Exchange and thirteen years for NASDAQ-listed stocks. ${ }^{352}$ These numbers are in stark contrast to the average fifty-five years for firms listed on the pan-German stock exchanges. ${ }^{353}$ The share of less-than-ten-year-old companies listed in the stock exchange is about forty percent in the United States, compared to $0.7 \%$ in Japan. ${ }^{354}$ A recent OECD analysis concludes that, compared to the United States, both Germany and Japan have a comparative disadvantage in hightechnology sectors. ${ }^{355}$ This empirical analysis is also borne out by casual observation. Germany and Japan have nowhere near the number and variety of firms that we see in the United States in high R\&D- and human capitalintensive sectors such as computer software, the internet, information technology, media, and biotechnology. ${ }^{356}$ A U.S.-style venture capital industry is virtually non-existent in either country. ${ }^{357}$

b. Changes in the Governance Systems. The three governance systems are, of course, not static. The past decade has witnessed evolutionary shifts in all three systems, but arguably, the nature of changes in Germany and Japan, relative to their underlying focus historically, has been more dramatic than that in the United States.

There are a number of changes underway in the U.S. system of corporate governance including the increasing influence of the sentiments reflected in the ALI Project on Corporate Governance, ${ }^{358}$ the shifting roles of institutional

pra note 345, at 838. Data for France pertain to 1993, and are found in Editorial, Olivetti's Lesson, WALL ST. J., Sept. 5, 1996, at A16.

350. See generally IMF, supra note 239; Olivetti's Lesson, supra note 349.

351. See OECD GERMANY, supra note 236, at 117.

352. See id.

353. See id.

354. See FUKAO, supra note 247, at 70-71.

355. See OECD GERMANY, supra note 236, at 102.

356. See Business in Europe Survey: Small Beginnings, ECONOMIST, Nov. 23, 1996, at 13-14.

357. See generally Bernard S. Black \& Ronald J. Gilson, Venture Capital and the Structure of Capital Markets: Banks Versus Stock Markets, 47 J. FIN. ECON. 243 (1998) (comparing U.S. capital markets to those of Germany and Japan). California alone generated more venture capital funds in 1996 than did Britain, France, Germany, and the Netherlands. See Start-Ups, ECONOMIST, Dec. 6, 1997, at 113.

358. See Carol B. Swanson, Corporate Governance: Sliding Seamlessly into the Twenty-First Century, 21 J. CORP. L. 417, 430-32 (1996). See generally AMERICAN LAW INSTITUTE, supra note 213. 
shareholders and independent directors on boards; ${ }^{359}$ the attempts to delink the jobs of chairpersons and $\mathrm{CEO} ;{ }^{360}$ the recent changes in proxy-voting rules instituted by the SEC; ${ }^{361}$ the Delaware court rulings on the importance of incumbent-firm strategy in takeover contests; ${ }^{362}$ the regulatory moves away from director liability; ${ }^{363}$ and the increasingly contractarian imperatives of the global financial markets. However, as discussed earlier, these changes do not appear to challenge in any fundamental way the United States's outsider orientation or

359. The increased role of institutional investors is apparent in the various corporate governance principles that have been proposed and promulgated by large pension funds such as the California Public Employees Retirement System ("CalPERS") and in the annual rankings of "governance grades" given to various companies. A recent study uses the governance grades given by CalPERS as a control variable in assessing corporate performance and finds that there are significant improvements in corporate performance, as measured by Economic Value Added, for those companies graded higher by CalPERS. See Ira Millstein \& Paul MacAvoy, The Active Board of Directors and Improved Performance of the Large Publicly Traded Corporation, 98 COLUM. L. REV. 1283 (1998). Millstein and MacAvoy document substantial evidence on the governance pressures faced by U.S. corporations from large public pension funds. With respect to the heightened roles of independent directors, the article cites an impressive array of evidence from a number of surveys of board composition during the 1990s which have found increased roles for outside and independent directors. See INVESTOR RESPONSIBILITY RESEARCH CTR., INVESTOR RESPONSIBILITY RESEARCH CENTER BOARD PRACTICES 1996, 3-6 (noting that nearly two-thirds of directors in 435 Standard \& Poors 500 companies are independent; four out of five companies have boards where independent directors comprise a majority); KORN/FERRY INT'L, TWENTIETH ANNUAL BOARD OF DIRECTORS STUDY 3 (1993) (showing that the proportion of insiders on board was $25 \%$ in 1992, compared to $38 \%$ in 1972). See generally Constance E. Bagley \& Richard H. Koppes, Leader of the Pack: A Proposal for Disclosure of Board Leadership Structure, 34 SAN DIEGo L. REV. 149 (1997); Sanjai Bhagat \& Bernard Black, Board Composition and Firm Performance: The Uneasy Case for Majority Independent Boards, 1053 CORP. GOVERNANCE InST. 95 (1998); Bernard S. Black, Agents Watching Agents: The Promise of Institutional Investor Voice, 39 UCLA L. REV. 811 (1992); Charles M. Elson, Director Compensation and the ManagementCaptured Board: The History of a Symptom and a Cure, 50 SMU L. REV. 127 (1996); Ronald J. Gilson \& Reinier Kraakman, Investment Companies as Guardian Shareholders: The Place of the MSIC in the Corporate Governance Debate, 45 STAN. L. REV. 985 (1993); Ronald J. Gilson \& Reinier Kraakman, Reinventing the Outside Director: An Agenda for Institutional Investors, 43 STAN. L. REV. 863 (1991); Jeffrey N. Gordon, Institutions as Relational Investors: A New Look at Cumulative Voting, 94 CoLUM. L. REV. 124 (1994); John H. Matheson \& Brent A. Olson, Corporate Law and the Longterm Shareholder Model of Corporate Governance, 76 MINN. L. REV. 1313 (1992); Park McGinty, Replacing Hostile Takeovers, 144 U. PA. L. REV. 983 (1996); Charles W. Murdock, Corporate Governance: The Role of Special Litigation Committees, 68 WASH. L. REV. 79 (1993); Edward B. Rock, The Logic and (Uncertain) Significance of Institutional Shareholder Activism, 79 GEO. L.J. 445 (1991); James M. Tobin, The Squeeze on Directors—Inside is Out, 49 BUS. LAW. 1707 (1994).

360. See Harold M. Williams \& Irving S. Shapiro, The 1979 Benjamin F. Fairless

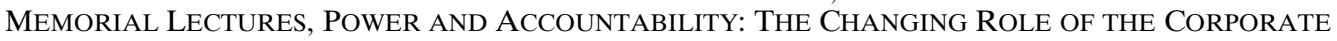
BOARD 18 (1979); see also JAY W. LORSCH \& ElIZABETH MACIVER, PAWNS OR POTENTATES: THE REALITY OF AMERICA's CORPORATE BOARDS 184-87 (1989); Martin Lipton \& Jay W. Lorsch, $A$ Modest Proposal for Improved Corporate Governance, 48 BUS. LAW. 58 (1992).

361. See generally Joseph Evan Calio \& Rafael Xavier Zahralddin, The Securities and Exchange Commission's 1992 Proxy Amendments: Questions of Accountability, 14 PACE L. REV. 459 (1994). See also Norma M. Sharara \& Anne E. Hoke-Witherspoon, The Evolution of the 1992 Shareholder Communication Proxy Rules and their Impact on Corporate Governance, 49 BUS. LAW. 327 (1993).

362. See Randall S. Thomas, Judicial Review of Defensive Tactics in Proxy Contests: When is Using a Rights Plan Right?, 46 VAND. L. REV. 503, 514-24 (1993). See generally Richard C. Brown, The Role of the Courts in Hostile Takeovers, 93 DicK. L. REV. 195 (1989); Lawrence A. Cunningham \& Charles M. Yablon, Delaware Fiduciary Duty Law After QVC and Technicolor: A Unified Standard (and the End of Revlon Duties?), 49 Bus. LAw. 1593 (1994); Alex Devience, Jr., A Hindsight Review of the Business Judgment Rule in a Takeover Environment: The State of the Business Judgment Rule after the Fall, 5 DePAUl BUS. L.J. 113 (1992-93).

363. See supra notes $132-133$ and accompanying text. 
its focus on shareholder value and financial returns. Indeed, many of the changes in the U.S. governance system may be in the direction of actually strengthening its underlying contractarian focus. Further, there do not appear to be any systematic or widespread moves either in boardrooms or in the realm of public policy to make U.S. firms more communitarian in their approach to governance. On the other hand, the changes in Germany and Japan appear to be moving firms in a direction away from their traditional insider/communitarian focus.

Consider the German case first. Although the German governance system continues to meet stiff resistance from unions and employees and although some of the changes may be halting, many basic features of the system appear to be under severe stress. The sources of such stress include regulatory changes both at home and from the European Union directives, the imperatives of corporate decisionmaking in the context of eroding competitiveness in globalized financial and product markets, and grassroots shareholder activism.

During the past decade, many of the regulations prohibiting or constraining the issuance of equity and market debt have been dismantled in Germany. ${ }^{365}$ Insider trading laws have been passed; ${ }^{366}$ consideration is being given to changes in corporate law to allow firms to repurchase shares; ${ }^{367}$ firms are now allowed to pay their sick workers only eighty percent of full pay; ${ }^{368}$ banks are being encouraged to divest their corporate shareholdings and to reduce their lending exposures to individual companies; ${ }^{369}$ major revisions of bankruptcy laws are under discussion; ${ }^{370}$ efforts are underway to develop a new set of standards for financial disclosure, ${ }^{371}$ German investors are now required to reveal the details of share ownership of more than five percent in a company; ${ }^{372}$ a new supervisory authority for securities trading is in the process of being created, ${ }^{373}$ special tax incentives are being offered for start-up firms in high-risk industries; ${ }^{374}$ foreign share ownership rules have been relaxed; ${ }^{375}$ and, as a result, foreigners now

364. See, e.g., A Specter in Europe: Shareholders Demand Rights, InT'L HERALD TRIB. Apr. 28, 1998, at 11; Shareholder Rights Go Global, INT'L HERALD TRIB. Apr. 7, 1998, at 11; The Outsider, ECONOMIST, June 3, 1995, at 66.

365. See Prowse, supra note 245, at 27.

366. See OECD GERMANY, supra note 236, at 120.

367. See Stefan Wagstyl et al., Crumbs from the Table, FIN. TIMES, Sept. 25, 1996, at Comment \& Analysis 27.

368. Until recently, firms were required to pay $100 \%$; this change resulted in major strikes and work stoppages in Germany in the last quarter of 1996. See Edmund Andrews, New Hard Line by Big Companies Threatens German Work Benefits, N.Y. TIMES, Oct. 1, 1996, at A1 (noting that "the Parliament approved a broad new bill that reduces the minimum required sick pay from $100 \%$ of pay for six weeks to $80 \%$ "); see also Blue Monday, WALL ST. J., Nov. 6, 1996, at A18.

369. See OECD GERMANY, supra note 236, at 120.

370. See FUKAO, supra note 247, at 123.

371. See OECD GERMANY, supra note 236, at 120.

372. See Stakeholder Capitalism: Unhappy Families, ECONOMIST, Feb. 10, 1996, at 23.

373. See OECD GERMANY, supra note 236, at 120.

374. See id. at 121.

375. See Business in Europe: Investor Power, ECONOMIST, Nov. 23, 1996, at 11-12. 
own nearly twenty percent of the shares in Germany, up from negligible amounts in the $1950 \mathrm{~s} .{ }^{376}$

Substantial changes are underway at the German corporate level as well. An increasing number of firms are listing their shares abroad, especially in the Anglo-American markets; ${ }^{377}$ some degree of corporate restructuring through sale of unprofitable units, spin-offs to increase shareholder value, downsizing, and deconglomeration appear to be underway; ${ }^{378}$ and a few major companies have introduced stock-option schemes as part of top-management compensation. $^{379}$

The changes in the German corporate sector are exemplified in perhaps an exaggerated way-although the extent of exaggeration may be a matter of degree rather than kind-by the case of its largest industrial company, DaimlerBenz. $^{380}$ During the 1980s, the company diversified aggressively, primarily through acquisitions, from its core automotive business to such increasingly unrelated businesses as aerospace, microelectronics, white goods, and financial services. Many of these acquisitions turned out to be unprofitable, and from 1986 to 1993, the market value of the company declined from DM50.5 billion to DM25.3 billion, its operating income declined from DM6.13 billion to a negative DM6.76 billion, and its operating cash flow as a percentage of sales declined from $10.43 \%$ to $7.15 \%{ }^{381}$ Faced with an increasing cash-flow crisis and the need to expand its sources of capital, in 1993, Daimler-Benz listed its stock on the New York Stock Exchange under SEC-mandated U.S. GAAP rules of disclosure. ${ }^{382}$ Fewer than two years later, there was a CEO change, and the new CEO was viewed as "putting profits ahead of strategy and treat[ing] shareholders as owners rather than serfs." pany reduced its workforce by 70,000 , reduced the proportion of shares held by both its hausbank shareholders, Deutsche Bank and Commerzbank-and more

376. See European Business: Le Defi Americain, Again, ECONOMIST, July 13, 1996, at 21-22.

377. See id. at 21.

378. See Wake Up or Die, ECONOMIST, Nov. 23, 1996, at 8; see also European Business, supra note 376 , at $22-23$.

379. See Business in Europe, supra note 375, at 12. See generally European Business, supra note 376. The Economist also discusses how the well-known German firm Siemens is transforming itself into a shareholder-value corporation by adopting Economic Value Added, a popular variant of the standard-discounted-cash-flow model, into its operating and financial strategy. See A Star to Sail By?, ECONOMIST, Aug. 2, 1997, at 53. In a related article, Siemens' controller Thomas Seeberg stated, "We want more capital-markets influence in our management systems." Greg Steinmetz, Siemens AG Remembers its Shareholders, WALL ST. J., Feb. 19, 1998, at A17.

380. Data are derived and calculated from data in Disclosure/Worldscope CD-ROM (on file with authors). See generally Business in Europe, supra note 375; European Business, supra note 376.

381. See generally Business in Europe, supra note 375; European Business, supra note 376.

382. The listing occurred after months of dispute with the U.S. Securities and Exchange Commission regarding adoption of U.S. disclosure standards. Soon after the U.S. listing and reporting under U.S. GAAP standards, the company reported its first loss since World War II, a loss of nearly one billion Deutchmarks. However, it showed a profit under German accounting rules. Asked how the company could show a profit, its then-CEO Edzard Reuter said, "Speaking frankly, we made use of a German accounting rule that allowed us to release reserves." John Schmid, Daimler Benz Reports First Ever Loss, Reflecting New Accounting, Lower Sales, WALL ST. J., Sept. 20, 1993, at A10.

383. Dismantling Daimler-Benz, ECONOMIST, Nov. 18, 1995, at 67. 
generally, reduced the number of closely held shares from 34.5 million to 26.0 million-divested the Fokker aircraft division, instituted an internal management-control system based on the metric of return on equity, and offered its top management stock options and bonuses linked to share-price performance. $^{384}$

Daimler-Benz's friendly merger with the Chrysler Corporation in May 1998 reveals just how far the transformation of the company has progressed. It is difficult to imagine that such a combination, rooted in the pursuit of scope economies, could have occurred before 1993. Taken together, the 1990s have been witness to the Anglo-Americanization of the third largest German company, by market capitalization, and a stalwart of German governance. Given the recent changes at Siemens, ${ }^{385}$ Hoechst, ${ }^{386}$ and Deutsche Bank, ${ }^{387}$ we suspect we may look back on the changes within Daimler-Benz as a pivotal moment in the transformation of the German corporate governance system. ${ }^{388}$

The significant increase in merger and acquisition activity for German firms is another sign that the governance structure of these corporations is changing toward a more Anglo-American system. In the United States, M\&A activity was $232 \%$ greater $(60,407 / 26,000)$ in the 1990 s than in the 1980 s. In comparison, the number of successful acquisitions of German firms grew by $1,959 \%$ $(8,246 / 421)$ over the same period. For continental Europe as a whole, M\&A ac-

384. See id.

385. See Valuing Companies: A Star to Sail by?, ECONOMIST, Aug. 2, 1997, at 53.

Karl-Hermann Baumann, Siemens chief financial officer, says that the trains-to-telecoms giant, which will switch to EVA [Economic Value Added] in October, is now convinced that the focusing on shareholder value is the best way to ensure its long-term prosperity. A growing number of other companies in Europe, Asia and Latin America, have reached the same conclusion-and are turning to consultants offering 'performance metrics' to measure Id. how much value is being created (or destroyed).

386. See Greg Steinmetz \& Matt Marshall, The Lazy Man of Europe, WALL ST. J., Mar. 18, 1997, at A1.

About the only thing German about Hoechst AG these days is its hard-to-pronounce name. Following massive job reductions at home last year, the world's biggest chemicals company now employs more people on the other side of the Atlantic than in Germany....

$\ldots$

With global competition more intense than ever, German companies are making themselves Id. more international and, in many cases, more American.

387. See Industry in Germany: Has it Changed?, ECONOMIST, Apr. 6, 1996, at 68.

Germany's biggest bank, Deutsche Bank, and its biggest industrial firm, Daimler-Benz, are proposing to offer the first share-option schemes. ...

$\cdots$

On March 27th Veba, a conglomerate involved in energy, trading and telecoms, became the second German company, after Daimler, to report financial performance according to American accounting standards, which are more revealing than German ones. A day later Deutsche Bank used international standards to report its annual accounts for the first time, Id. disclosing Deutsch Marks 20 billion (\$14 billion) of previously hidden reserves.

388. For more details on the transformation of Daimler Benz and its governance implication, see Dennis E. Logue \& James K. Seward, Anatomy of a Governance Transformation: The Case of Daimler-Benz, 62 LAW \& CONTEMP. PROBS. 87 (Summer 1999). 
tivity was $1,275 \%$ greater $(33,687 / 2,643) .{ }^{389}$ Interestingly, while the number of successful hostile acquisitions of U.S. targets has fallen dramatically in the most recent decade--163 between 1981 and 1989 compared to fifty-six between 1990 and 1998--the number of hostile takeovers of firms in continental Europe has actually increased from eight to seventeen.

Finally, the number of German firms that recently have listed their shares on the New York Stock Exchange indicates a trend toward a more AngloAmerican governance structure. None of the eight German firms with American Depositary Receipts ("ADRs") currently trading on the NYSE was listed before $1996{ }^{390}$

A recent article in the Wall Street Journal reflected on the changes occurring in German corporations:

German banks are losing their domestic influence to a burgeoning capital market that forces companies to heed investor wishes. A spate of cross-border mergers is giving firms more global reach. And once-close ties among government, industry and labor are unraveling.

There's no doubt Germany will remain Europe's economic kingpin, its companies among the world's mightiest. But experts say the very foundation of Europe's powerhouse, which has been envied and emulated for decades, is giving way to a new structure that borrows from a different model.

The signs of accelerating change are everywhere. Companies have been on a buying spree outside Germany that is helping create stateless corporations with looser ties to home. The value of crossborder deals involving German companies jumped fourfold in 1998 , to $\$ 92.8$ billion, according to Goldman, Sachs \& Co.

$\ldots$

Germany is also being shaken by a profound shift of power away from banks and toward broad-based equity markets. Over the past five years Deutsche Bank has unloaded stakes in nine major firms and reduced investments in dozens more.

Meanwhile, the number of companies trading on the Frankfurt Stock Exchange has more than tripled since 1995 to 2,244. Sixty-four of them are young, fast-growing firms that have listed on the exchange's two-year-old Neuer Markt, which gives access to capital to fledgling companies that in the past would have had difficulty prying a loan out of banks.

Similar changes are occurring elsewhere in Europe. The OECD reports that the governance systems of France, Switzerland, the Netherlands, and Sweden are moving closer to the Anglo-American model, whereas they previously

389. See Securities Data Corporation database (program and results on file with author).

390. The eight firms are Celanese (1999), Deutsche Telekom (1996), Epcos (1999), Fresenius Medical Care (1996), Pfeifer Vacuum (1996), SAP Aktiengesellschaft (1998), SGL Carbon (1996), VEBA (1997). See New York Stock Exchange (visited Jan. 24, 2000) $<$ www.nyse.com/international.htm $>$.

391. David Woodruff, Banks' Loss of Influence, Cross Border Mergers Force More-Global Style, WALl ST. J., Mar. 11, 1999, at A18. 
had more closely followed the German model. ${ }^{392}$ There are significant corporate governance debates underway in France. Many of the changes in both the regulations and the conduct of French corporations parallel those chronicled above for the German case. ${ }^{393}$ France is currently debating the introduction of private-pension-funding schemes along the lines of those in the United States. In both France and Italy, there is an increasing number of high-profile cases in which minority shareholders are demanding and obtaining adequate rights, especially in matters concerning takeover premia. ${ }^{394}$ Norms are also being developed to limit multiple-board memberships among a small group of financial and corporate elites. ${ }^{395}$ Perhaps most telling, since 1998, there have been five hostile acquisitions of French companies, each with a market value in excess of one billion dollars. ${ }^{396}$

There are other examples of this trend toward the Anglo-American system across Europe. In Italy, a group of U.S. and U.K. fund managers were able, by virtue of their recently acquired majority share ownership, to successfully replace Carlo de Benedetti, the CEO of Olivetti SpA, due to poor performance. $^{397}$ Although, in this instance, de Benedetti ultimately was able to neutralize the efforts of these institutional shareholders by installing a top manager from one of his other subsidiaries as the new CEO, the moves by the foreign institutional shareholders suggest at least the beginnings of an Anglo-Americanstyle battle for boardroom control in the Italian governance setting. ${ }^{398}$ Competition laws and antitrust regulations are being strengthened and more forcefully

392. See OECD GERMANY, supra note 236, at 19.

393. The French phrase for corporate governance is "le corporate governance." See Allanna Sullivan \& Thomas Kama, Continental Shift: Elf Aquitane's Chief Illustrates the Changes in Europe's Executives, Wall ST. J., Apr. 9, 1996, at A1.

394. For a chronicle of such cases, see Business in Europe, supra note 375, at 11-12; see also John Tagliabue, A Specter in Europe: Shareholders Demand Rights, INT'L HERALD TRIB., Apr. 28, 1998, at 11; France's Boardroom Revolution, WALL ST. J., Oct. 17, 1995, at A20. For a comprehensive description of the corporate governance reform efforts underway, including a "Marini Report" of the French Senate to reform the rights of minority shareholders in France, see ORGANIZATION FOR ECON. COOPERATION AND DEV., ORGANIZATION FOR ECONOMIC COOPERATION AND DEVELOPMENT ECONOMIC SURVEYS: FRANCE 128-29 (1997) [hereinafter OECD FRANCE] (noting that "[o]verall, the transition appears to have gone on the direction of shareholder (outsider) model and ... the French system is now closer to the Anglo-American model").

395. This recommendation is contained in the Viénot Report, the report produced by a corporate governance committee formed in France and headed by Marc Viénot, the CEO of Société Générale. See OECD FRANCE, supra note 394, at 130 (summarizing the Viénot Report and comparing it to the so-called Cadbury Report in the United Kingdom); European Business, supra note 376, at 23 (discussing a number of corporate governance changes taking place in Europe).

396. Data are derived and calculated by the authors from the online mergers and acquisitions database of the Securities Data Corporation (calculations on file with authors).

397. See John Tagliabue, Profits and Pride are at Stake for Ailing Olivetti, N.Y. Times, Sept. 20, 1996, at D3.

398. See Business in Europe, supra note 375, at 11-12 ("[W]ithin a few weeks, Mr. De Benedetti was back in power. Well, not Mr. De Benedetti exactly, but one of his lieutenants, Roberto Colaninno ...."); see also Tagliabue, supra note 397, at D3 (chronicling the Olivetti event). 
applied in the European Union. ${ }^{399}$ Moreover, there are significant moves toward the adoption of a common set of accounting and disclosure rules under the International Accounting Standards. ${ }^{400}$

In Japan, financial markets were liberalized to a significant degree during the 1980s. ${ }^{401}$ The Japanese government also recently announced new plans for further deregulation of the banking, securities, foreign exchange, and insurance sectors to take effect by 2001, along the lines of the "Big Bang" in London. ${ }^{402}$ Other changes are similarly underway that challenge the status quo in Japanese corporate governance: Some keiretsu firms are reportedly beginning to sell their stockholdings; ${ }^{403}$ the notion of lifetime employment is under serious debate; ${ }^{404}$ after a few years of slowdown, 1996 saw a resurgence in the market for mergers and acquisitions, with more than 600 deals valued at more than one trillion yen being completed; ${ }^{405}$ a significant number of large corporations have moved toward arms-length relations with their main banks as Japanese banks are losing their capacity to act as enforcers of financial discipline; ${ }^{406}$ Japanese firms have become far more dependent on international capital markets for their global funding needs for both debt and equity, and the proportion of bank financing to total capitalization has steadily declined during the past decade; and the number of firms listing their shares in the Anglo-American stock markets has risen substantially during the past decade, to the point where thirtyfour percent of the largest, by market capitalization, 100 Japanese firms listed

399. See The Irritating Commissioner, ECONOMIST, Jan. 31, 1998, at 72 (describing the increase in the aggressiveness and "free market zealotry" of antitrust enforcement in the European Union under the new Competition Commissioner).

400. See InTERNATIONAL ACCOUNTING STANDARDS COMMITTEE, INTERNATIONAL ACCOUNTING STANDARDS COMMITTEE InSIGHT 15 (Oct. 1997). The International Accounting Standards Committee ("IASC") is an international group of financial institutions, corporations, and policymakers, such as stock exchange authorities and central bankers, that has undertaken the task of formulating a common set of accounting standards worldwide. The Insight reports that as of the end of 1996, 56 of 67 countries that they surveyed either used the International Accounting Standards ("IAS") as their national standards or based their national standards primarily on IAS. The United States, however, has decided to continue with its own standards. See id.

401. See Prowse, supra note 245, at 26.

402. See Laying the Charge for the Big Bang, BANKER, July 1, 1997, at 108, 108-09; see also Changing Japan: Whispering Reform, ECONOMIST, Jan. 11, 1997, at 19, 19; see also Survey Japanese Finance, ECONOMIST, June 28, 1997, at 2, 2-3.

403. See Stakeholder Capitalism: Unhappy Families, ECONOMIST, Feb. 10, 1996, at 25 (noting that "some keiretsu may have begun to unravel; under financial pressure, some partners have recently started to sell their cross-shareholdings"); see also Japan Inc. Frays at the Edges, ECONOMIST, June 3, 1995, at 67, 67 (noting that "[a] sluggish economy is putting unprecedented pressure on the system of cross-shareholdings that binds Japanese companies and banks together").

404. See Stakeholder Capitalism, supra note 403, at 25 (noting that "the lifetime employment of core workers is increasingly under threat" and that "Japanese firms are redefining 'lifetime employment,' pointing out that it applied only to a proportion of workers and whittling down the proportion as much as they can").

405. See Velisarios Kattoulas, Japan Catches Merger Fever Again, InT'L HerAld TrIB., Jan. 2, 1997, at 9.

406. See OECD GERMANY, supra note 236, at 20. 
on the Tokyo stock exchange are also now listed on either the U.S. or the U.K. stock markets. ${ }^{407}$

The Asian economic crises that began in the latter half of 1997-with the attendant economic contraction, currency depreciation, plummeting stock markets, soaring unemployment, and banking crises-affecting Japan, Thailand, Indonesia, Malaysia, the Philippines, and Korea have brought into sharper focus the nature of corporate governance practices in those economies. Numerous writers, policymakers, and commentators have alluded to the opacity and crony capitalism in the governance systems in these economies, arguing that these attributes have exacerbated the crises, if not actually engendered them. ${ }^{408}$ Of course, it is too early to forecast just how these events will transform these economies, their politics, laws, institutions, and corporate governance practices. However, it is clear that these economies, like the post-communist economies of Eastern Europe and the former Soviet Union, are in transition into a new and uncharted governance territory. At a minimum, these events legitimately have raised questions about the efficacy of communitarian styles of governance and their ability, or lack thereof, to cope with a world in which international capital flows, globalization, and human-capital-intensive technologies have become the norm. Arguably, they also have resulted in the increasing acceptance of the notion that the adoption of some form of contractarian governance mechanisms in the Anglo-American tradition-with their transparent, marketdriven, shareholder-oriented styles-may be the long-term solution.

407. Data are derived and calculated from Disclosure/Worldscope CD-ROM (on file with authors).

408. Although there have been voluminous viewpoints on the Asian economic crisis, all of it is in the realm of the public media at the time of this writing, and, unfortunately, little has yet to appear in the academic realm. A sampling of some of the articles-perhaps just their headlines-colorfully reveals the views on the crisis. See generally Michel Camdessus, Drawing the Appropriate Lessons from the Asia Crisis, InT'L Herald TrIB., Apr. 7, 1998, at 8; Michel Camdessus, Korea and Thailand Begin to Rise as Indonesia Lags, INT'L HERALD TRIB., Apr. 6, 1998, at 10; Ron Chernow, Sayonara to Japan Inc., Wall St. J., Dec. 3, 1997, at A22; Industrial Policy Caused South Korea's Collapse, WALl ST. J., Dec. 8, 1997, at A24; Holman W. Jenkins, Jr., A Last Waah! For Japan's Crybabies, WALL ST. J., Dec. 3, 1997, at A23; Shanthi Kalathil, Asia Gets a Hard Lesson in Costs of Firms' Murky Bookkeeping, WALl ST. J., Dec. 15, 1997, at A19; Nicholas D. Kristoff, Crisis Pushing Asian Capitalism Closer to U.S.-Style Free Market, N.Y. TIMES, Jan. 17, 1998, at A1; George Melloan, This Year's Economic Lesson: Japan's Model Failed, WALL ST. J., Dec. 30, 1997, at A11; Steven Mufson, Chaebol Reform: Like Redoing the Whole Economy, INT'L HERALD TRIB., Dec. 24, 1997, at 15; Reality Hits Japan, ECONOMIST, Nov. 29, 1997, at 15; Paul M. Sherer, World Bank's Tricky Task in Thailand: Mine Into Mountains of Corporate Debt, WALl ST. J., Apr. 2, 1998, at A17; South Korea: The End of the Miracle, ECONOMIST, Nov. 29, 1997, at 21; Meredith Woo-Cummings, How Asia's Financial Foibles Make American Way Look Like a Winner, WALL ST. J., Dec. 8, 1997, at A1.

For somewhat more academic viewpoints on the Asia crisis, see Steven Radelet \& Jeffrey Sachs, The East Asian Financial Crisis: Diagnosis, Remedies, Prospects, HaRv. Inst. InT'L Dev., Apr. 20, 1998; Paul Krugman, What Happened to Asia (visited Oct. 4, 1999) $<$ http://web.mit.edu/krugman/www/DISINTER.html>; Raghuram Rajan \& Luigi Zingales, Which Capitalism? Lessons from the East Asian Crisis, J. APPLIED CORP. FIN., Fall 1998, at 40; Janet Yellen, The Impact of the Asia Crisis on the U.S. (Address before the Council of Economic Advisors, Apr. 24, 1998). For an impressive, and constantly updated, compendium of hundreds of articles relating to the Asia crisis, see the web page maintained by Prof. Nouriel Roubini at the Stern Business School at New York University (visited Oct. 4, 1999) <http://www.stern.nyu.edu/ nroubini/asia/AsiaHomepage. html>. 
A particularly compelling example of such acceptance comes from Japan. A 1998 statement of corporate governance principles for Japan, issued by a Corporate Governance Committee of the Corporate Governance Forum of Japan, ${ }^{409}$ derives its principles based on the primacy of creation and management of shareholder value as the basic managerial goal and role of board independence in achieving that goal. ${ }^{410}$ The report notes that Japanese boards of directors as currently constituted have not been "equipped with sufficient governance authority or capability, while the board of auditors has been little more than a cosmetic shell," ${ }^{411}$ that "the board of directors tends not to have real decision making power," 412 and that currently "a sufficient supply of independent external directors does not exist in Japan." term, the uniquely Japanese system of cross-shareholding might begin to unravel, which will necessitate a system of governance more reliant on independent and external directors, in turn leading to the creation of a market for such individuals." ${ }^{\text {"14 }}$ The report argues for the creation of a U.S.-style concept of fiduciary duty to shareholders and implies that the current Japanese concepts of such duty may be somewhat vague, covered as they are by legal concepts such as bona fide loyalty duty and the duty of honest manager's care. ${ }^{415}$

In both Continental Europe and Asia, many other such examples abound. But the evidence presented here reveals that the evolutionary shifts underway in both these geographic areas appear to be posing significant challenges to their traditionally insider-oriented, stakeholder-based, relatively communitarian systems of corporate governance. Moreover, the governance systems of the three major industrial economies of the world-the United States, Germany, and Japan - seem to be inexorably moving toward some practical form of convergence. The nature of this movement is inarguably in the Anglo-American direction rather than the other way around.

This conclusion is quite different from the prevailing sentiment in the literature on comparative corporate governance. W. Carl Kester, for example, captures the prevailing sentiment quite clearly:

Since the early 1980s a kind of competition among systems of corporate governance has emerged. Despite the twentieth century international hegemony of first the United Kingdom, followed by the United States, it is by no means certain that the Anglo-American system of governance as currently configured will win this competition. 416

409. See generally CORPORATE GOVERnANCE COMMITTEe, CORPORATE GOVERnANCE Forum of JAPAN CORPORATE, GOVERnANCE PRINCIPLES: A JAPANESE VieW (FINAL RePORT) (May 26, 1998). The Committee, constituted in 1994, consists of 17 leading Japanese corporate executives, institutional investors, media representatives, and lawyers. Details on the Committee, its meetings, and its deliberations, can be found in the Report. See id. at 33, 35.

410. See id. at 45-54.

411. Id. at 37.

412. Id. at 41 .

413. Id. at 42 .

414. Id.

415. See id. at 43.

416. Kester, supra note 325. 
Additionally, Kester mentions that Mark J. Roe has tied these shifts to the political roots in their respective settings but Roe notes that it may be a mistake to pronounce one system as more advantageous than another. ${ }^{417}$ Andrei Shleifer and Robert W. Vishny, in a similar vein, argue that "all these economies have the essential elements of a good governance system, [and] the available evidence does not tell us which one of their governance systems is the best." $" 418$

Our conclusion that the economies of the world, and the corporate forms residing therein, are evolving toward a more contractarian structure follows from our analysis above and is rooted in the following assessment of the purposes and accountability of the public corporation in an ever-changing, global economy.

\section{IV}

\section{THE PuRPoses AND ACCOUNTABILITY OF THE CORPORATION}

Having identified the major forces of change that are occurring in the environment of the contemporary corporation, reviewed the two primary paradigms of the corporate form, and examined the two primary alternative governance structures observed throughout the world, this article now turns to the question of the purposes and accountability of the corporation in contemporary society. It concludes that the purpose of the corporation should continue to be to maximize the value of its residual claimants - stockholders-within the constraints imposed by law, social norms, customs, and mores. Furthermore, there is no need to jettison the basic tenets of the contractarian view of the corporation to achieve this purpose.

To be sure, in its starkest manifestation, the contractarian view leaves unresolved several critical issues-most notably the so-called third-party effects. As discussed above, the fundamental underpinning of the contractarian model is the ability of individuals to enter into enforceable contracts. Clearly, there are numerous situations in which neither the affected parties nor future events can be anticipated ex ante and contracted around. However, one should not view the contractarian model in isolation. Rather, it should be viewed as the foundation of a corporate governance structure, augmented by rules established through democratic processes, much like it is in the United States today. The plethora of legislative reforms documented above that address the rights and welfare of individuals outside of the corporate contracting process have mitigated many of these third-party effects, and it is expected that future legislation will do likewise. There is, therefore, within the contractarian paradigm, a sepa-

417. See W. Carl Kester, American and Japanese Corporate Governance, Convenience to Best Practice?, in NATIONAL DIVERSITY \& GLOBAL CAPITALISM 107-37 (Suzanne Berger \& Ronald Dore eds., 1996). See generally Mark J. Roe, The Political Roots of American Corporate Finance, J. APPLIED CORP. FIN., Winter 1997, at 19.

418. Shleifer \& Vishny, supra note 2, at 739. 
rate and distinct role for corporate managers on the one hand and elected government officials on the other.

While this preference for the contractarian view over the more communitarian governance structures of Europe and Asia might seem provincial, the emerging evidence suggests that these alternative governance structures are evolving toward the practices observed in the United States. There are at least three structural, and hence possibly long-lasting, reasons why organizations in the industrialized nations are gravitating toward the contractarian model, all related to the inexorable development of a unified, global economy. The first is the ability to attract capital, particularly foreign capital. Rafael La Porta and others have shown that the size of external capital markets in a particular country is directly related to rules and regulations that focus on shareholder protection. ${ }^{419}$ Because shareholder welfare is at the center of the contractarian model, it is no surprise to find that firms seeking to attract foreign investors are refashioning their organizational structures in the image suggested by this paradigm. As further evidence of this trend, witness the revision in accounting and reporting practices adopted by German firms seeking to have their shares listed on the New York Stock Exchange. ${ }^{420}$

The second reason firms are migrating toward the contractarian model is the extent of global competition in product markets. Firms can no longer afford to be content to dominate their domestic markets. Rather, they must compete head-to-head with international firms. Global competition, with its exacting form of Darwinian discipline, requires firms to be more profit-driven. Increasingly, a contractarian governance structure is a necessary condition for success, if not survival.

Finally, the third cause for the trend toward more contractarian firms is the rapid pace of change in the global marketplace. The significant corporate restructuring activity that has taken place during the 1980s and 1990s in corporate America never could have taken place within the context of a communitarianbased economy. ${ }^{421}$ The rigidities of the traditional German and Japanese governance structures hinder adaptation to the ever-quickening changes in the global marketplace.

These three reasons are the basis of our disagreement with the views of Roe, ${ }^{422}$ Shleifer and Vishny, ${ }^{423}$ and Kester ${ }^{424}$ regarding the German and Japanese systems of governance being not only good, but self-sustaining and separate from the Anglo-American system. While their arguments might be justifiable if all economies were autarkic, the imperatives of the new, open, global economy are different. The sheer depth and breadth of the global competition

419. See generally La Porta et al., supra note 16.

420. See supra notes $381,389-93$ and accompanying text.

421. See Comment \& Jarrell, supra note 342; Davis et al., supra note 342.

422. See RoE, supra note 19; Roe, supra note 233.

423. See Shleifer \& Vishny, supra note 2.

424. See Kester, supra note 417. 
for capital, people, technologies, and products dictate that some form of a Darwinian shakeout could well occur. ${ }^{425}$ One reasonably might argue about the extent and the speed of the changes taking place in the other systems. It is conceded that the inertia in these systems creates frictions that hinder change, but the direction of the change is inarguable. This view also draws upon and is bolstered by the arguments of Frank H. Easterbrook that the law itself is an output of the process of the drive toward economic efficiency, rather than the other way around. ${ }^{426}$ In other words, the efficiencies and the contractarian imperatives of global competition actually may help propel changes in the underlying legal, political, and social infrastructures in the relatively more communitarian economies.

This belief, and even faith, in the contractarian model is not without concerns, however. Of particular concern is the absence of international institutions with the authority to enforce the contracts that are the threads which keep the fabric of the contractarian model from unraveling. Without a worldwide contractarian infrastructure, the promise of the Anglo-American system of governance cannot be realized. It speaks to the question of accountability, at home and abroad. These concerns are addressed in the following section.

\section{VOIDS AT THE INTERSECTION OF SOVEREIGN BOUNDARIES}

Contractarianism identifies to the necessary conditions for a system of corporate governance. The changes identified in Table 2 reveal the problems associated with an underdeveloped or absent contractarian infrastructure. Four conditions must be met to overcome these problems. First, disclosure rules are needed to provide all contracting parties with information that is as complete as possible. Second, a system of contract laws is necessary to establish the terms of trade. Third, an impartial judiciary is required to enforce those laws. Finally, the entire system must be flexible and adaptive to continued changes in business conditions. The problem today is that the institutions that might provide such a worldwide infrastructure do not exist in most instances, or, where they do, they are at best forums for voluntary acceptance of jurisdiction, mediation, and enforcement. Thus, problems of opaque operating characteristics and sovereign voids grow worse.

425. This kind of broad view runs counter to a view that allows for a variety of governance practices to flourish in local niches. Ronald J. Gilson best articulates the opposing perspective: "It is going to be very hard to sit at a great distance and make broad statements about the way corporate governance should be. Analysis has to be increasingly textured and tailored to the practical circumstances of an industry." Ronald J. Gilson, The Future of Corporate Governance in the United States, 31 U. RICH. L. REV. 1459, 1465 (1997). This view is shared in the sociology literature as well. See Neil Fligstein \& Robert Freeland, Theoretical and Comparative Perspectives on Corporate Organization, 21 ANN. REV. Soc. 21, 21 (1995) ("Our review of the comparative literature suggests that there is no evidence of convergence across societies toward a single form of governance ....").

426. See Frank H. Easterbrook, International Corporate Differences: Markets or Law?, J. APPLIED CORP. FIN., Winter 1997, at 23 (1997). 
The obvious solution to this problem is to establish a worldwide contractarian infrastructure. What is not so obvious is how to do that. Focusing on the development of international trade law, Luis Olavo Baptista acknowledges the problem and notes two paths that might lead to this result. ${ }^{427}$ The first, and least acceptable, is to coordinate laws across systems on a case-by-case basis. Baptista refers to this approach as the "elaboration of permanent rules." 428 Standard clauses and contracts would be applied as needed on a case-by-case basis. In time, a standardized infrastructure might emerge from this practice. The problem, of course, is that this process will take time. There are also no guarantees that any kind of efficient and effective legal framework will evolve from this approach.

The second approach is to work toward a harmonious integration of differing systems. ${ }^{429}$ While different, the various countries' laws would be inspired by similar goals. Such treaties as WTO, and its precursor, GATT, ${ }^{430}$ Mercosur, ${ }^{431}$ the EU, ${ }^{432}$ and NAFTA ${ }^{433}$ help to establish goal congruence.

This is not to say that there has been no movement to establish international organizations to fill these voids at the borders. As outlined in Table 4, there has been a proliferation of cross-border laws, treaties, conventions, etc., or, more generally, "instruments," dealing with direct foreign investments in the post-World War II era. According to the United Nations, the twenty-fouryear period from 1947 to 1971 witnessed the creation of eighteen such instruments, of which fourteen were adopted; the following twenty-five-year period from 1972 to 1996 witnessed a tripling to fifty-five such instruments, with fortyfive adopted. ${ }^{434}$

427. See Luis Olavo Baptista, The UNIDROIT Principles for International Commercial Law Project: Aspects of International Private Law, 69 TUL. L. REV. 1209, 1212 (1989) ("International trade leads to a closer interrelationship between countries, especially in the economic sense, and thus demands the security of uniform laws.").

428. Id. at 1212 .

429. See id. at 1214.

430. See General Agreement on Tariffs and Trade, Oct. 30, 1947, 61 Stat. A-11, T.I.A.S. 1700, 55 U.N.T.S. 194.

431. MERCOSUR is a Latin American trading bloc originally comprised of Argentina, Brazil, Paraguay, and Uruguay. See Treaty Establishing a Common Market Between the Argentine Republic, the Federative Republic of Brazil, the Republic of Paraguay, and the Eastern Republic of Uruguay, Mar. 26, 1991, art. 1, 30 I.L.M. 1041, 1044.

432. See Treaty Establishing the European Community, Feb. 7, 1992, O.J. (C 224) 1, (incorporating changes made by Treaty on European Union, Feb. 7, 1992, O.C.C. 224/1.

433. North American Free Trade Agreement, Dec. 17, 1992, art. 1902 (1), 32 I.L.M. 605.

434. See United NATIONS, WORLD INVESTMENT REPORT 1996: InVESTMENT, TRAdE AND INTERNATIONAL POLICY ARRANGEMENTS 135-39 tbl.v.2 (1996). 
TABLE 4

INTERNATIONAL INSTRUMENTS* DEALING WITH

DIRECT FOREIGN INVESTMENT:

1948 TO 1996

\begin{tabular}{lccc}
\hline Period & $\begin{array}{c}\text { Number of Multi- } \\
\text { lateral/Int'l In- } \\
\text { struments }\end{array}$ & $\begin{array}{c}\text { Number of Re- } \\
\text { gional/Bilateral } \\
\text { Instruments }\end{array}$ & Number Adopted \\
\hline $1948-61$ & $4(50 \%)$ & $4(50 \%)$ & $6(75 \%)$ \\
$1962-71$ & $2(20 \%)$ & $8(80 \%)$ & $8(80 \%)$ \\
$1972-81$ & $12(52 \%)$ & $11(48 \%)$ & $16(70 \%)$ \\
$1982-96$ & $15(47 \%)$ & $17(53 \%)$ & $29(91 \%)$ \\
Totals & & & \\
& $33(45 \%)$ & $40(55 \%)$ & $59(81 \%)$ \\
\end{tabular}

* "Instruments" include Codes, Conventions, Charters, Agreements, Treaties, Rules, U.N. Resolutions, Declarations, and Principles.

Source: United NATIONS, World InVESTMENT REPort 1996: InVESTMENT, TRADE, AND INTERNATIONAL POLICY ARRANGEMENTS 135-39 tbl.v.2 (1996).

The third solution is to move toward unification. The trend toward codifying international law is now almost one hundred years old. ${ }^{435}$ The Hague Conference on Private International Law has been meeting since $1893 .{ }^{436}$ While no supranational body can draft and enforce such unified laws without cooperation from sovereign nations, the United Nations has taken significant steps toward addressing the problem. The U.N. General Assembly established the U.N. Commission on International Trade Law ("UNCITRAL") in $1966 .{ }^{437}$

435. See Franco Ferrari, Defining the Sphere of Application of the 1994 "UNIDROIT Principles of International Commercial Contracts," 69 TUL. L. REV. 1225 (1995).

436. See generally K. Lipstein, One Hundred Years of Hague Conferences on Private International Law, 42 INT'L \& COMP. L.Q. 553 (1993); Peter H. Pfund, The Hague Conference Celebrates Its 100th Anniversary, 28 TEX. INT'L L.J. 531 (1993).

437. The U.N. General Assembly established UNCITRAL in 1966 by the passage of Resolution 2205 (XXI). G.A. Res. 2205, U.N. GAOR, 21st Sess., Supp. No. 16, at 99, U.N. Doc. A/6394/Add. 1/Add. 2 (1966). UNCITRAL is a formal committee of the United Nations and is composed of representatives from 36 nations. It is the United Nations' primary legal committee in the field of international trade law. Among other things, UNCITRAL drafts model laws, holds international conventions on topics related to international trade law, and publishes legal guidelines. UNCITRAL has an impressive list of projects that have since been published in brochures or legal guides. Convention on the 
UNCITRAL was formed to facilitate the "progressive harmonization and unification of the law of international trade."

The key UNCITRAL project in the field of international contracting is the U.N. Convention on Contracts for the International Sale of Goods ("CISG"). ${ }^{439}$ CISG presents a comprehensive code governing contracts for the international sale of goods, analogous to an international version of the Uniform Commercial Code. ${ }^{440}$ Currently, at least fifty-seven countries have ratified the Convention. $^{441}$ Other developoments include the Case Law on UNCITRAL Texts ("CLOUT"), a reporter of UNCITRAL-based cases from around the world.

Limitation Period in the International Sale of Goods, June 14, 1974, S. Treaty Doc. No. 103-10 (1980) 1151 U.N.T.S. 99; Convention on Contracts for the International Sale of Goods, entered into force Jan. 1, 1988, S. Treaty Doc. No. 98-9 (1983), 1489 U.N.T.S. 3; Convention on the Carriage of Goods by Sea, entered into force Nov. 1, 1992, 1695 U.N.T.S. 3; Convention on the Liability of Operators of Transport Terminals in International Trade, Apr. 19, 1991, 30 ILM 1503 (1991) (not yet in force); Convention on International Bills of Exchange and International Promissory Notes, Dec. 9, 1988, 28 ILM 170 (1989) (not yet in force); Convention on Independent Guarantees and Stand-by Letters of Credit, Dec. 11, 1995, 35 ILM 735 (1996); UNCITRAL Model Law on International Commercial Arbitration, U.N. GAOR, U.N. Doc. A/40/17 (1985); UNCITRAL Model Law on International Credit Transfers, U.N. Doc. A/CN.9/384 (1992); UNCITRAL Model Law on Procurement of Goods, Construction, and Services, with Guide to Enactment, U.N. Doc. A/CN.9/Ser. A (1995); UNCITRAL Model Law on CrossBorder Insolvency, U.N. Doc. A/CN.9/442 (1997); UNCITRAL Model Law on Electronic Commerce, U.N. Doc. A/CN.9/XXX IX/CRP. 1/add. B (1996) (1996); UNCITRAL Arbitration Rules, U.N. Doc. A/CN.9/SR.178 (1976); UNCITRAL Conciliation Rules adopted and reprinted by G.A. Res. 35/52, U.N. GAOR $35^{\text {th }}$ Sess. Supp. No. 17, U.N. Doc. A/35/17 (1980); UNCITRAL Notes on Organizing Arbitral Proceedings, U.N. Sales No. E.97.V.11 (1996); UNCITRAL Legal Guide on International Countertrade Transactions, U.N. Doc. A/CN.9/Ser.B/31 (1993); UNCITRAL Legal Guide on Drawing Up International Contracts for the Construction of Industrial Works, U.N. Doc. A/CN.9/Ser.B/2 (1988); UNCITRAL Legal Guide on Electronic Funds Transfers, U.N. Doc. A/CN.9/Ser.B/1 (1987). See UNCITRAL (last modified Apr. 20, 1999) <http://www.uncitral.org $>$. It contains the actual text of UNCITRAL's model laws and other projects and is fairly informative about the general scope and aims of UNCITRAL. See also John D. Franchini, International Arbitration Under the UNCITRAL Arbitration Rules: A Contractual Provision for Improvement, 62 FORDHAM L. REV. 2223, 2224-26 (1994).

438. G.A. Res. 2205, supra note 437, at 42, 43; see also Franchini, supra note 437, at 2224-25.

439. At the Vienna Convention in 1980, UNCITRAL presented CISG which entered into force in 1988 when the United States, China, and Italy ratified the convention. See Harold S. Burman, Building on the CISG: International Commercial Law Developments and Trends for the 2000's, 17 J.L. \& CoM. 355 (1998).

440. The actual textual provisions of CISG can be accessed at the UNCITRAL website: "This Convention establishes a comprehensive code of legal rules governing the formation of contracts for the international sale of goods, the obligations of the buyer and seller, remedies for breach of contract, and other aspects of the contract." UNCITRAL (last modified Apr. 20 1999) <http://www.uncitral.org>. See generally Paul Amato, Recent Development: CISG: U.N. Convention on Contracts for the International Sale of Goods-the Open Price Term and Uniform Application: An Early Interpretation by the Hungarian Courts, 13 J.L. \& COM. 1 (1993); V. Susanne Cook, From the Perspective of the Practitioner, 17 J.L. \& CoM. 343 (1998); Lisa M. Ryan, The Convention on Contracts for the International Sale of Goods: Divergent Interpretations, 4 TUL. J. INT'L \& COMP. L. 99 (1995); Richard E. Speidel, Symposium - The Impact of Internationalization of Transnational Commercial Law: The Revision of UCC Article 2, Sales in Light of The United Nations Convention on Contracts for the International Sale of Goods, 16 Nw. J. INT'L L. \& BUS. 165 (1995).

441. The UNCITRAL website contains a current list of all countries that have ratified. See UNCITRAL, supra note 440. Some of the nations that are parties to the Convention signed with reservations. CISG is limited to contracts for the sale of goods, yet it has the force of law in countries where it has been adopted. In the United States, CISG is a federal treaty and, as such, preempts state Uniform Commercial Code laws. CISG preempts the Uniform Commercial Code whenever foreign parties whose nations have ratified the convention contract for the sale of goods. See Speidel, supra note 440 , at $166-67$. 
The goal is for CLOUT to serve as suggested interpretations for judges, arbitrators, and attorneys in countries that have ratified the Convention.

Perhaps the most significant development to date, from a corporate governance standpoint, has been UNCITRAL's role in the development of crossborder insolvency laws. ${ }^{43}$ The UNCITRAL Model on Cross-Border Insolvency ("Model Law"), developed in 1997, attempts to move away from the traditional notion of territoriality to that of universality in jurisdictions. ${ }^{444}$ The Model Law currently is receiving serious consideration in both the legislative and executive branches of the U.S. government. There is a bill to reform U.S. bankruptcy laws pending in the U.S. Congress. The bill incorporates the provisions of the Model Law, and the U.S. Treasury has endorsed the changes. ${ }^{445}$

442. See UNCITRAL, supra note 440. Some evidence indicates that CLOUT acts primarily as a source of information but fails to create the necessary legal obligations to fully harmonize decisions under CISG. See Hannu Honka, Harmonization of Contract Law Through International Trade: A Nordic Perspective, 11 TUL. EUR. \& CIV. L.F. 111, 179 (1996).

443. UNCITRAL opted to draft a model law rather than a convention because of concerns that a convention would not be ratified. This fear likely is based on the failed efforts of both the Council of Europe at the Istanbul Convention in 1990 and the European Union Convention of Insolvency Proceedings. Neither of these conventions on cross-border insolvency were ratified. Thus, UNCITRAL drafted a model law instead, allowing countries to enact the Model Law exactly as drafted or in a modified form. See Andre J. Berends, The UNCITRAL Model Law on Cross-Border Insolvency: A Comprehensive Overview, 6 TUL. J. INT'L \& COMP. L. 309, 316-18 (1998).

444. The territoriality view holds that the ramifications of an insolvency proceeding do not extend beyond the boundaries of the nation wherein the insolvency proceeding was opened. When the assets of insolvent debtors are located in a number of different countries, this problem necessitates a separate insolvency proceeding in each country and the appointment of a number of different liquidators. It is also possible that the claim may be recognized in one proceeding but refused in another. Moreover, small creditors may find it too costly to file a claim abroad. On the other hand, the universality view calls for only one proceeding to administer all assets, wherever they are located. Under this view, insolvency proceedings in one country are fully recognized in other countries. See Berends, supra note 443, at 313-14; see also Burman, supra note 439, at 357-58.

445. See Burman, supra note 439, at 358. The Bankruptcy Reform Act before Congress as section 601 incorporates the Model Law as part of the proposed amendment. The Model Law is to become Chapter 6 to Title 11 of the U.S. Bankruptcy Code. H.R. 3150, 105th Cong. (1998). Currently, another bipartisan bill is under consideration as H.R. 833. This bill is identical to the Conference Report on H.R. 3150. See ABI Testifies on Bankruptcy Reform Bill, 1999 AM. BANKR. JNL. LEXIS 32 (1999). John Barrett, the United States delegate to the UNCITRAL committee that drafted the Model Law on Cross-Border Insolvency, believes that the Bankruptcy Reform Act will pass through the Senate. He acknowledges that "there is controversy with other aspects of the bill that may require amending. [However] this is not likely to affect the Model Law provisions." John A. Barrett, Various Legislative Attempts with Respect to Bankruptcies Involving More than One Country, 33 TEX. INT'L L.J. 557, 557

(1998). A working group of the U.S. Treasury attributes the following advantages to the Model Law:

The UNCITRAL Model Law on Cross-Border Insolvency, once enacted, could be useful in the following ways. Among other things, it creates a procedural mechanism that would allow for the imposition of a creditor moratorium protecting the international assets of a firm undergoing insolvency proceedings; provides a foreign representative with access to local insolvency proceedings; provides a transparent regime for foreign creditors to commence, or participate in, insolvency proceedings in a given state; and permits courts in a given state to cooperate more effectively with foreign courts. Rules on cross-border insolvency and recognition of foreign proceedings should enable better coordination in the case of multijurisdictional insolvencies and thus facilitate more orderly workouts as well as allow countries to be better prepared for the increased incidence of cross-border insolvencies stemming from the expansion of global trade and investment.

Report of the Working Group on International Financial Crises (last modified Oct. 1998) $<$ http://www.ustreas.gov/press/releases/docs/g22-wg3.htm>. For a background on the problem of cross- 
These developments are quite impressive, given that they have occurred so soon after the creation of the Model Law.

Such attempts at cross-border integration of laws are not restricted to governments and multilateral institutions. Private organizations also have shown significant interest in international contracting. The International Institute for the Unification of Private Law ("UNIDROIT"), ${ }^{446}$ founded in 1926, created a set of principles for cross-border commercial contracting in 1994. The UNIDROIT principles represent the most recent and ambitious attempt to provide an example of unified contract terms that can be employed worldwide. It remains to be seen if UNIDROIT's ambitions will be fulfilled.

Although developments such as UNCITRAL and UNIDROIT are significant steps forward, the problems that remain and the new ones that will arise cannot be minimized. Consider, for example, the attempts to harmonize corporate law in the European Union. Despite impressive convergence on a host of economic and political issues, including moving toward the adoption of a common currency, members of the European Union have been mired in discussions and disputes for almost a quarter century on the question of adoption of an E.U.-wide corporate law. Similarly, scholars have long argued for the creation of a WTO-type cross-national body for the supervision of multinational corporations and for the creation of a uniform set of corporate standards worldwide, but to little avail. ${ }^{447}$ Nationalism typically stymies such efforts. ${ }^{448}$

border insolvency, see Robert K. Rasmussen, A New Approach to Transnational Insolvencies, 19 MICH. J. INT'L L. 1 (1997).

446. See UNIDROIT, INTERNATIONAL INSTITUTE FOR THE UNIFICATION OF PRIVATE LAW, PRINCIPLES OF INTERNATIONAL COMMERCIAL CONTRACTS (1994). See also E. Allan Farnsworth, An International Restatement: The UNIDROIT Principles of International Commercial Contracts, 26 U. BALT. L. REV. 1 (1997); Ferrari, supra note 435, at 1228 n.23. It is interesting to note that E. Allan Farnsworth, reporter for the Restatement Second of Contracts, was the United States's delegate to UNCITRAL and a member of the working group that drafted CISG. He was also the only American member of UNIDROIT's governing council and participated in drafting the UNIDROIT Principles. Farnsworth comments that the UNIDROIT Principles borrowed very extensively from CISG, much more than either CISG or the UNIDROIT Principles borrowed from the Uniform Commercial Code. See generally E. Allan Farnsworth, The American Provenance of the UNIDROIT Principles, 72 TUL. L. REV. 1985 (1998); Klaus Peter Berger, International Arbitral Practice and the UNIDROIT Principles of International Commercial Contracts, 46 AM. J. CoMP. L. 129 (1998); Michael Joachim Bonell, The UNIDROIT Principles of International Commercial Contracts: Why? What? How?, 69 TUL. L. REV. 1121 (1995); Alejandro M. Garro, The Gap-Filling Role of the UNIDROIT Principles in International Sales Law: Some Comments on the Interplay Between the Principles and the CISG, 69 TUL. L. REV. 1149 (1995); Sarah Howard Jenkins, Exemption for Nonperformance: UCC, CISG, UNIDROIT Principles-A Comparative Assessment, 72 TUL. L. REV. 2015 (1998); Gonzalo Parra-Aranguren, Conflict of Law Aspects of the UNIDROIT Principles of International Commercial Contracts, 69 TUL. L. REV. 1239 (1995); Maria del Pilar Perales Viscasillas, UNIDROIT Principles of International Commercial Contracts: Sphere of Application and General Provisions, 13 ARIZ. J. INT'L \& COMP. L. 381 (1996); Hernany Veytia, The Requirement of Justice and Equity in Contracts, 69 TUL. L. REV. 1191 (1995); Ferrari, supra note 435; Baptista, supra note 427.

447. See generally Paul M. Goldberg \& Charles P. Kindleberger, Toward a GATT for Investment: A Proposal for the Supervision of the International Corporation, 2 LAW \& POL'Y INT'L BUS. 295 (1970); Peter Hansen \& Victoria Aranda, An Emerging International Framework for Transnational Corporations, 14 FORDHAM INT'L L.J. 881 (1990-91).

448. For an impassioned plea for American protectionism in the face of global free trade, see PATRICK J. BUChANAN, THE GREAT Betrayal 288 (1998). The essays by Robert Boyer, The Convergence Hypothesis Revisited: Globalization But Still the Century of Nations?, in NATIONAL DI- 
It also should be pointed out that if international law does not step in to fill the void, firms must do it themselves, not only through alliances and joint ventures, but also with some sort of bonding mechanism. In other words, firms may have to create the enforcement rules, mechanisms, and incentives themselves, a prospect that may not be altogether appealing. Variants of such mechanisms conceivably could include the more odious forms of enforcement (for example, Mafia-style control mechanisms) that are currently observed in settings where the contractarian infrastructure is still evolving or absent. ${ }^{449}$

\section{VI}

\section{CONCLUSION}

This article began with the recognition that most research on corporate governance is of a cross-sectional nature and derives from the rather limited view that good corporate governance simply requires solving an agency problem between the firm and its capital providers as mediated by its top management. It discussed the need not only for a time-series approach, but also for an enlargement of the relevant set of corporate constituencies on which governance attention must focus if the ability of firms to adjust to the ever-changing environment in which they operate is to be fully understood. Evidence was presented of a host of recent changes in the corporate form and its environment that have had a significant impact on the conduct of business, and it was concluded that the contemporary challenges facing managers and directors are unlike any they have faced before. These changes pose a number of discrete challenges to corporate governance. The very nature of the firm, its purposes, and its accountability to society are all in question.

These challenges have rekindled an age-old debate about the purposes and accountability of the firm. Both sides in the contractarian versus communitarian debate believe that a firm can and should be a source of wealth and wellbeing for society. The question is not about the ultimate purpose of the firm but rather about how the firm should fulfill its purpose or, indeed, repay its debt to society. This article concludes that contractarianism provides necessary, but not sufficient, conditions to govern the business enterprise. It is necessary to impose constraints on the system to control what have been called third-party effects and to adopt a worldwide contractarian enforcement infrastructure to overcome the voids at the intersection of sovereign boundaries.

VERSITY AND GlOBAl CAPITALISM 29-59 (Suzanne Berger \& Ronald Dore eds., 1996), and Robert Wade, Globalization and Its Limits: Reports on the Death of the National Economy Are Greatly Exaggerated, in NATIONAL DIVERSITY, supra, at 60-88, make the case that the nation-state is still a significant economic actor in an era of globalization. Indeed, they argue that the idea of economic and institutional convergence toward some ideal equilibrium is naive and denies the possibility of local equilibria born of the interests of the nation-state.

449. This is true in the former Soviet Union. See Criminals as Insurance Salesmen, ECONOMIST, July 18, 1995, at 52, 52; see also, Floyd Norris, The Russian Way of Corporate Governance, N.Y. TIMES, Apr. 5, 1999, at A22. 
There are at least three limitations to understanding corporate governance in this light. First, there is a glaring lack of evidence on whether and how communitarian structures of governance affect firm performance or stakeholder claims. Perhaps this is not surprising. Because much of the empirical research has been conducted in the contractarian context of U.S. corporations, these research agendas cannot, by design, address the larger questions surrounding the effectiveness and efficiency of contractarianism versus communitarianism. Second, while the vast majority of research on corporate governance sits squarely within the contractarian paradigm, it is almost entirely focused on governance relationships manifest within the firm. Because this work typically focuses on U.S. firms or firms in the world's other leading economies, it appears to take for granted the contractarian infrastructure that provides contracting information, monitoring, and enforcement capabilities. This is a mistake. Research on the evolution of these institutional contexts themselves is needed. Left unchecked, the community of scholars who study corporate governance may miss the essence of many governance problems. By focusing on governance challenges as they are revealed within firms, scholars may inadvertently investigate only symptoms of a more fundamental problem, a problem rooted not within the firm but rather in the firm's institutional environment.

The final limitation of contemporary governance work implicates the limits of the contractarian paradigm itself. Even if an efficient and adaptive worldwide contractarian infrastructure could be established, and even if any attendant agency costs could be ameliorated, stakeholder abuse may be manifest in some form. The deepest challenge then is to find a way to enact communitarian sentiments in a contractarian world. 